TEATRO DEL OPRIMIDO UNA ESTRATEGIA PEDAGÓGICA CON NIÑOS Y NIÑAS DEL CENTRO DE PROYECCIÓN SOCIAL SANTO DOMINGO; DESDE EL LIBRO LOS CERDOS DE A. BROWNE

SANDRA PAOLA RAMOS MORENO

UNIVERSIDAD SANTO TOMÀS

FACULTAD DE FILOSOFÌA Y LETRAS

MAESTRİA EN ESTUDIOS LITERARIOS

BOGOTÀ D.C., SEPTIEMBRE DE 2018 


\section{EL TEATRO DEL OPRIMIDO UNA ESTRATEGIA PEDAGÓGICA CON NIÑOS Y NIÑAS DEL CENTRO DE PROYECCIÓN SOCIAL SANTO DOMINGO; DESDE EL LIBRO LOS CERDOS DE A. BROWNE}

\section{SANDRA PAOLA RAMOS MORENO}

Trabajo de grado como requisito para optar el título de Magister en Estudios Literarios

Tutora:

MYRIAM JIMENEZ QUENGUAN

UNIVERSIDAD SANTO TOMÀS FACULTAD DE FILOSOFÌA Y LETRAS MAESTRİA EN ESTUDIOS LITERARIOS BOGOTÀ D.C., SEPTIEMBRE DE 2018 


\section{Dedicatorias}

A Dios por brindarme fortaleza en los momentos difíciles e iluminarme el camino. Por permitirme vivir una experiencia tan constructiva en mi vida profesional y personal.

A mis padres y mi esposo por el gran apoyo que me han brindado en todo el proceso. 


\section{Agradecimientos}

A la profesora Myriam Jiménez Quenguan, quien con su acompañamiento constante me apoyo durante el proceso de investigación. 


\section{Resumen}

El propósito del proyecto es diseñar una estrategia pedagógica, que permita crear y aplicar diez talleres de teatro en torno al cuento Los cerdos de Anthony Browne, para fomentar habilidades comunicativas a partir de la realidad de los niños y niñas que acuden al Centro de Proyección Social Santo Domingo en la ciudad de Bogotá, Colombia. El interés surgió por la deficiencia que se observa en la competencia comunicativa de los educandos y, una desmotivación hacia la literatura. El taller como estrategia pedagógica contribuye a la formación integral del ser humano; por ello, esta investigación se construye a partir de la teoría y el método del Teatro del Oprimido de Augusto Boal y, la pedagogía de la liberación de Paulo Freire.

Bajo un paradigma cualitativo, un tipo de estudio etnográfico y de acción participación, inicialmente se procedió a realizar la selección de la población, a través de una encuesta aplicada a la comunidad del barrio Juan XXIII; como criterio de inclusión se tuvo en cuenta la edad de los niños, de 7 a 13 años y el interés por el teatro; en total participaron durante todo el proceso 19 niños, que desarrollaron los talleres todos los sábados de febrero a mayo de 2018. Para la recolección de información, además de los talleres, se llevó un diario de campo, registros fotográficos y videos; con base en todo lo recolectado se sistematizaron experiencias de los niños y la profesora en el aula. lo que permitió dar sentido y verificar la relación experiencia y teoría. Posteriormente se desarrolló la propuesta teatral desde la creatividad de los niños y su particular contexto.

Esta propuesta pedagógica logró demostrar como si se trabaja la expresión corporal, la lectura, la escritura y la oralidad es posible afianzar las habilidades comunicativas. Igualmente, contribuyó a estimular el potencial de la imaginación y a la construcción de un pensamiento crítico y reflexivo en los niños y niñas. Al mismo tiempo los talleres despertaron su gusto e interés por el libro-álbum y en general por la literatura y el teatro; un resultado importante de destacar es la realización de un guión teatral colectivo y la puesta en escena del mismo frente a su comunidad. De esta manera, este proyecto contribuyó desde la didáctica de la literatura a mejorar las prácticas en la educación, logrando un impacto favorable en la población estudiada. 


\section{Contenido}

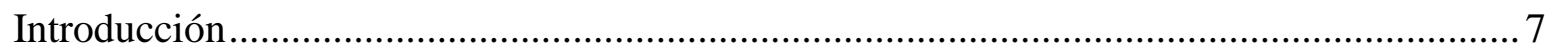

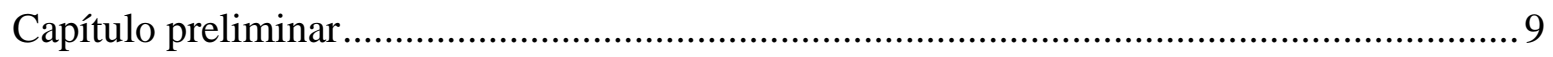

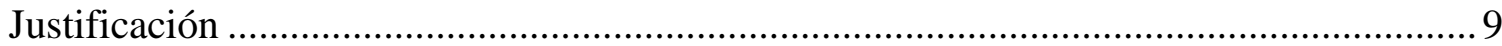

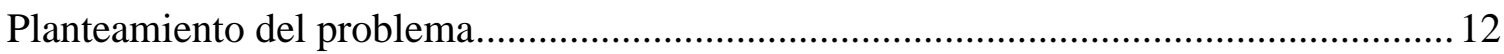

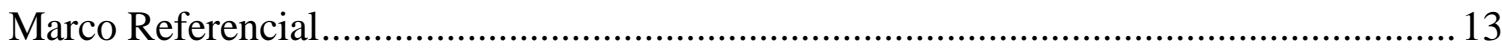

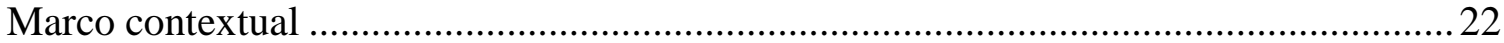

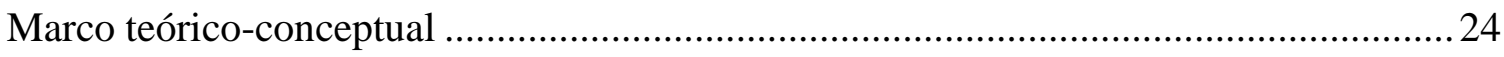

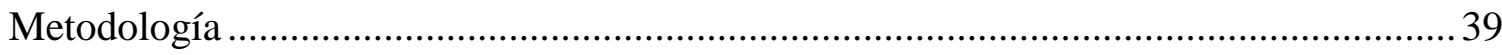

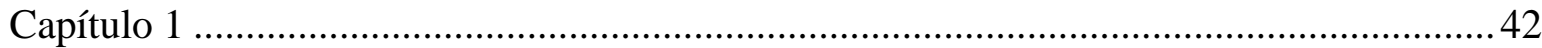

1.1Encontrándonos con la literatura y el teatro ..................................................... 42

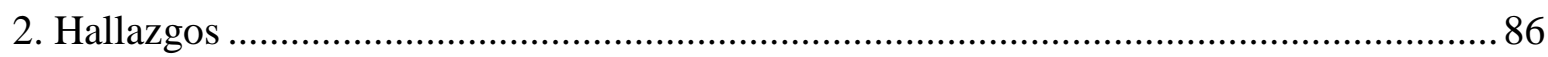

2.1. El universo de los niños del barrio Juan XXIII.................................................... 86

2.2 Habilidades comunicativas encontradas en los niños del barrio Juan XXIII..............88

2.3La estrategia del teatro del oprimido para fomentar las habilidades comunicativas ...90

2.4. Producto final: Guión teatral y puesta en escena ................................................ 92

2.5 Triangulación de toda la información .............................................................. 92

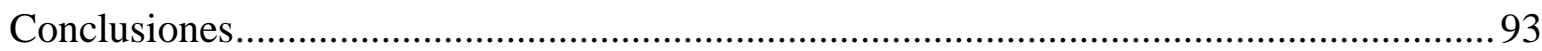

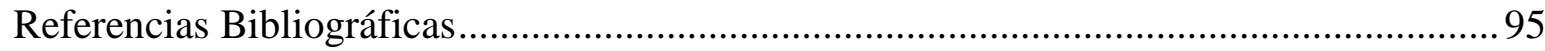

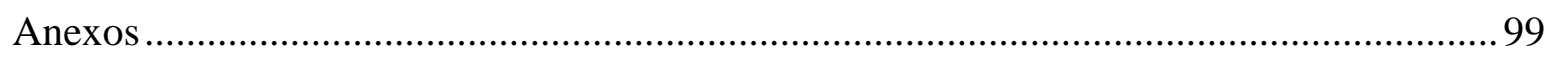

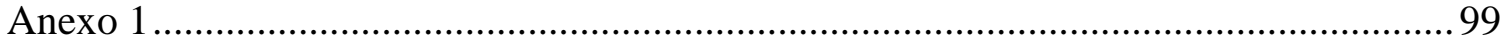

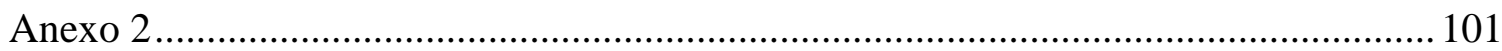

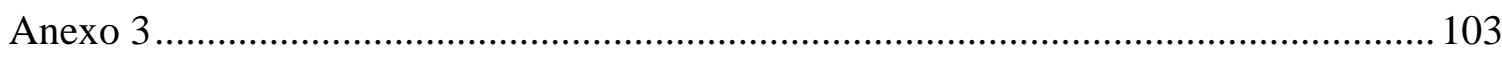

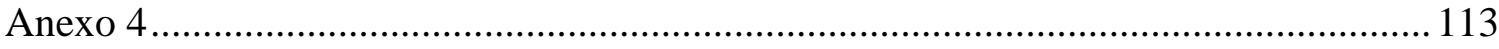




\section{Introducción}

El proyecto El teatro del oprimido una estrategia pedagógica con niñas y niños del Centro de Proyección Social Santo Domingo desde el Libro de los cerdos de Anthony Browne se inició en el año 2018 cuando surgió la idea y la necesidad de articular la literatura y el arte dramático para fomentar las habilidades comunicativas en los educandos. Por experiencias anteriores se ha evidenciado debilidades en la lectura y la escritura porque en las instituciones educativas los docentes enseñan estos procesos de forma mecánica y no permiten a los estudiantes explorar otras dimensiones al leer y escribir, existiendo el imaginario que éstas habilidades solo hacen parte del contexto académico. Por lo cual, se aplicaron los talleres en el Centro de Proyección Social Santo Domingo con niños de siete a trece años, primero se hizo un reconocimiento del contexto, siendo fundamental, ya que en primera instancia se identificaron elementos de su cotidianidad, sus experiencias, sus emociones, los intereses y necesidades propias de la edad, se pudo comenzar con un conocimiento de sí mismos, de su familia y barrio mediante la expresión artística como es el teatro y la literatura con base con el texto narrativo El libro de Los Cerdos de Anthony Browne.

Se realizaron varias indagaciones sobre los sistemas de actuación de grandes teóricos como Meyerhold (1986), Stanislavski (2003), Augusto Boal entre otros, con el fin de construir una propuesta pedagógica para mejorar las habilidades comunicativas concretamente lectura y escritura.

Después de la lectura de las propuestas de cada uno de los sistemas, se eligió la teoría y el método Augusto Boal, escritor, dramaturgo y director de teatro brasileño, quien, a través de la imaginación, fantasía, la creatividad, la concentración promueve el desarrollo a las habilidades comunicativas, artísticas y corporales.

El autor propone llevar a escena problemáticas de la realidad y los participantes deben construir soluciones simbólicas manifestando su reflexión y pensamiento crítico, con el objetivo que cada individuo las pueda poner en práctica en su vida diaria, es un ensayo de la realidad. Por lo tanto, se diseñó diez talleres con la teoría y método del Teatro del Oprimido desde el libro literario antes mencionado; aplicándose de febrero a marzo durante sesiones 
sabatinas de dos horas. Teniendo como producto final la escritura colectiva de un guión teatral y su respectiva puesta en escena.

A continuación, se presentan dos capítulos, el preliminar, justifica el fomento de las habilidades comunicativas a través del teatro y la literatura. Surgió la necesidad de diseñar diez talleres para fortalecer la lectura y escritura porque los niños presentan debilidades, ya que en la escuela se aprenden y se enseñan como procesos rígidos sin sentido teniendo una visión mecánica la cual no permite transcender a otros niveles, ni dimensiones ni diferentes contextos. Entonces, para incentivar el gozo y el placer por la literatura se seleccionó el libroálbum de Los Cerdos siendo una estrategia lúdica para leer imágenes y texto que cautiva a los educandos, además el tema se conecta con la realidad de los niños y con el método del Teatro del Oprimido podían manifestar su pensamiento crítico a través de la construcción de las soluciones simbólicas a la problemática planteada del machismo. Para lograr la propuesta se formuló un objetivo general y tres específicos que son los pasos para dar cumplimiento al proyecto. En el marco referencial están los antecedentes nacionales e internacionales acerca de las habilidades comunicativas a través del teatro y el Teatro del Oprimido para incentivar el pensamiento crítico. El marco teórico-conceptual sustenta científicamente el proyecto desde la pedagogía de la liberación de Paulo Freire y la teoría y método de Augusto Boal. Por último, en la metodología se explica el tipo de investigación acción participativa del proyecto y el enfoque etnográfico que tiene se cumple ya que los niños vivieron la problemática, la analizaron, fueron actores activos de la construcción de la solución creando el guión teatral y puesta en escena para transformar sus vidas. Se utilizaron técnicas e instrumentos como la selección de la muestra, la observación participante, diarios de campo, videos y fotografías.

El segundo capítulo son los análisis e interpretación de los hallazgos, en la primera parte se describe los objetivos de cada taller, con las dos etapas de motivación y exploración de conocimiento o autoconocimiento con las actividades analizando las recurrencias y las grandes categorías estando articuladas con evidencias y teorías desde Freire y Boal. La segunda parte se establecen los hallazgos del trabajo de grado con base a los teóricos mencionados. Además, haciendo una triangulación de la información. 


\section{Capítulo preliminar \\ Introducción a la problemática, el universo teórico y metodológico del oprimido}

\section{Justificación}

El trabajo de grado propuso el diseño y aplicación de diez talleres de teatro en torno al cuento Los cerdos de Anthony Browne como estrategia pedagógica para desarrollar la competencia comunicativa de niños y niñas del Centro de Proyección Social Santo Domingo. Planteo utilizar el teatro como una mediación pedagógica para incentivar al desarrollo de un ser integral. Ya que el teatro tiene en cuenta

las profundas necesidades propias del desenvolvimiento humano: la construcción de sí mismo, la búsqueda de seguridad, de dignidad, de comunicación, desde el desarrollo de saberes y criterios acerca del código artístico con el que se "escribe" el hecho teatral. (González, 1998, p.40)

Aparte de lo anterior los talleres de teatro se propusieron como una estrategia didáctica basada en una metodología lúdico-creativa con el fin de transformar la visión de los niños ${ }^{1}$ sobre la lectura y la escritura, al mismo tiempo que fortalecer su competencia comunicativa. Es un espacio que se abrió para estimular la creatividad para que pudieran alcanzar un pensamiento divergente, comprender y producir textos desde su realidad. Asimismo, fue un espacio lúdico, que otorgo satisfacción y placer en el acercamiento a la literatura. "El juego es una actividad libre en vinculación a entidades normativas, permite a la persona desplegar sus virtualidades creadoras y se constituye -correlativamente- en fuente de gozo" (López, 1977, p. 72).

El trabajo de grado se realizó con niños de 7 a 13 años en el Centro de Proyección Social Santo Domingo de la Universidad Santo Tomás, ubicada en la localidad de Chapinero en la zona definida como Reserva Forestal (Cerros Orientales) y tiene su sede en el barrio Juan XXIII en la calle 65A Nro. 1-34. La Universidad

concibe la Proyección Social como una oportunidad para incidir en el mejoramiento de la calidad de vida de las personas y de las comunidades. Por ende, en el desarrollo social del país; se fundamenta en los principios humanísticos y cristianos, según el pensamiento de Santo Tomás de Aquino; por medio de la articulación de la

\footnotetext{
${ }^{1}$ Niños: Se refiere al género masculino y femenino.
} 
investigación y la docencia, socialmente pertinentes. Propicia el desarrollo de las habilidades y capacidades intelectuales de los estudiantes, a través de estrategias curriculares y dinámicas investigativas orientadas por los docentes, las cuales permiten liderar, en conjunto, procesos sociales para la transformación de la dinámica de la sociedad (Universidad Santo Tomás. Unidad de Proyección Social).

El proyecto desempeñó tres funciones: docencia, investigación y proyección social. La primera función como lo dije anteriormente, apunto a mejorar las prácticas pedagógicas en la literatura. El trabajo de grado busco analizar la viabilidad del taller de teatro con la metodología lúdico-creativa; y la proyección ayudo a los individuos a mejorar su calidad de vida, ya que "los juegos de roles llevan toda una carga emocional y social. Observaciones, experiencias y vivencias se transmiten y varían en situaciones lúdicas. En ellos se ejercita la creatividad social y expresiva a la vez que perfeccionan la comunicación” (De La Torre, 1982, p.36).

Por otra parte, fue pertinente la propuesta del proyecto en esta población, dado que:

Permite el desarrollo personal y social de los componentes del grupo, atendiendo principalmente al proceso. No solo fomenta el aprendizaje creativo, sino valores tan impredecibles en el desarrollo de la persona como el cultivo del respeto al otro, y consecuentemente la educación en la diversidad, la cooperación, la escucha, la resolución de conflictos desde la no violencia. (Mato, 2006, p. 10)

El taller de teatro además de estimular las competencias de lectura y escritura aportó posibles soluciones a los conflictos de violencia en la comunidad. Desde la comprensión de su mundo a partir de lecturas y escrituras de sus vidas con base al cuento Los cerdos se proyectó una reflexión sobre sí mismos y su entorno que los empodero como agentes de cambio en sus comunidades.

Por esta razón, el taller de teatro se fundamenta en la teoría y método del Teatro del Oprimido, constituido por Augusto Boal en los años 1971 y 1986 en Argentina y Perú principalmente. Ésta consiste en:

Un conjunto de juegos, ejercicios y técnicas que pretenden la desmecanización física e intelectual de sus practicantes y la democratización del teatro. Tiene por objetivo utilizar el teatro y las técnicas dramáticas como un instrumento eficaz para la comprensión y la búsqueda de alternativas a problemas sociales e interpersonales. Se trata de estimular a los participantes no-actores a expresar sus vivencias de situaciones cotidianas de opresión a través del teatro. (Motos, 2009, p.3)

El método del Teatro del Oprimido tiene como antecedente en la región el trabajo pedagógico de Pablo Freire. La teoría y método del teatro de oprimido está inspirado en el 
libro de Freire La pedagogía del oprimido (1970). En él Freire expone que se debe eliminar la contradicción de opresor-oprimido, los dos sujetos en diversas posiciones tienen que llegar a una liberación. Por medio del diálogo se conseguirá esa libertad y se transformará el ser. Asimismo, en su libro La pedagogía de la esperanza, un reencuentro con la pedagogía del oprimido (1993) el autor argumenta que los docentes progresistas tienen el objetivo de educar en la esperanza para no caer en la fatalidad con el fin de alcanzar la justicia y la equidad. En ambos textos Freire expone formar un individuo fuera de la educación bancaria o tradicional. Como plantea Escobar (1985) lo esencial de la propuesta de Freire es educar para obtener un pensamiento crítico y reflexivo por medio de la lectura y escritura de la realidad de cada individuo. No se propone seguir en la alfabetización mecanicista, sino transcender este punto para que los niños sean conscientes de las habilidades comunicativas. Así mismo Escobar destaca que la competencia comunicativa está involucrada en la vida cotidiana influyendo en como comprenden su realidad social. Los talleres se realizaron con la pedagogía liberadora de Freire. A partir de este enfoque pedagógico se pretendió que los niños, a través del taller de teatro, pudieran descubrir y entender su mundo, y tener herramientas suficientes para enfrentarse a una sociedad compleja, siendo actores no pasivos sino activos y centrales de su propio proceso de cambio.

El texto literario que se trabajó en el taller es el de Anthony Browne, autor e ilustrador de libros infantiles, conocido como uno de los creadores del libro-álbum en el mundo y ha sido traducido más de quince idiomas. La obra literaria Los cerdos se seleccionó de este autor porque su literatura aborda una crítica a la sociedad y su problemática. Como en este caso se aborda el tema de la construcción de género en el hogar, la constitución de familia y los valores. El cuento ayudo a "formar lectores que gocen de la lectura y la vivan como experiencia implica, más que promover la lectura, generar las condiciones para dejar leer, para permitir que el sujeto se enfrente al texto de manera personal" (Plan Nacional de Lectura y Escritura, 2011, p.12). La lectura del texto despertó el interés y el placer por la literatura, del mismo modo, sirvió para que los niños pudieran leer y escribir su realidad con el fin de comprender su mundo, haciendo la construcción simbólica de soluciones a problemáticas mediante el teatro del oprimido. 


\section{Planteamiento del problema}

En el aula se han evidenciado las debilidades frente a las habilidades de lectura y escritura puesto que en el ámbito escolar:

El aprendizaje de lectura y escritura es una cuestión mecánica, se trata de adquirir la técnica del descifrado del texto. Porque la escritura se concibe como la transcripción gráfica del lenguaje oral, como su imagen (más o menos fiel según los rasgos particulares), leer equivale el decodificar lo escrito en sonido. (Ferreiro, Teberosky, 1998, p. 19)

Por ello, se desea ir más allá del aprendizaje técnico buscando un sentido a los procesos de lectura y escritura, que los transforme en significativos para la vida de cada niño y niña deviniendo una herramienta para leer y narrar su realidad. Esta dificultad se aborda considerando un mejoramiento en la didáctica actual el cual brinde estrategias para despertar placer y gozo por la literatura, así mismo aportando a las prácticas pedagógicas.

González sostiene que existen "analfabetos funcionales (personas que pasaron por el sistema educativo y sin embargo no comprenden lo que leen ni pueden producir un texto adecuado en la situación comunicativa en la que se encuentran" (1998, p.41). Por lo que este proyecto responde a las necesidades del Distrito Capital teniendo en cuenta que la Secretaria de Educación del Distrito Capital y la CERLALC desde el año 2013 presentaron la "Propuesta para la incorporación de la lectura, la escritura y la oralidad en todos los ciclos y áreas del currículo escolar" a la comunidad educativa. Para llevar a cabo este proyecto:

Los maestros líderes diseñarán, implementarán y sistematizarán colectivamente propuestas didácticas para la enseñanza del lenguaje en el ciclo. Para ello, discutirán planteamientos teóricos en torno a la enseñanza de la lectura, la escritura y la oralidad, tomando como base el análisis y el diseño de situaciones didácticas concretas. (Ministerio de Educación Nacional. Agosto 15 de 2013)

Partiendo de esa realidad, se consideró que a través de una propuesta concreta como es la teoría y método del Teatro del Oprimido se podía trabajar con niños de 7 a 13 años para fomentar las habilidades comunicativas con base en el libro Los Cerdos de Anthony Browne. Durante tres meses, en sesiones sabatinas de dos horas con el fin de incentivar la lectura y la escritura a partir de sus realidades. El trabajo de grado fue viable ya que el Centro de Proyección Social Santo Domingo favoreció la apertura para los talleres de teatro y literatura. 
El Teatro del Oprimido es pertinente por cuanto ofrece las bases suficientes para reforzar las habilidades de comprensión y expresión en los niños. El método de Boal se ajustó al proyecto dado que permite no solo incentivar las habilidades comunicativas sino la reflexión y pensamiento crítico en cada uno de los individuos.

\section{Objetivos}

\section{Objetivo General}

Diseñar e implementar una estrategia pedagógica a partir del teatro del oprimido en torno al cuento Los cerdos de Anthony Browne, para fomentar las habilidades comunicativas a partir de la realidad de los niños y niñas del Centro de Proyección Social Santo Domingo

\section{Objetivos Específicos}

1. Caracterizar la población y su respectivo contexto para identificar la realidad sociocultural.

2. Fomentar las habilidades comunicativas desde el cuento Los cerdos de Anthony Browne para que los niños desarrollen el placer, el gozo por la lectura y el lenguaje crítico.

3. Aplicar una estrategia pedagógica de liberación de Los cerdos de Anthony Browne, a través de talleres de lectura y escritura, fundamentados en la teoría y estética teatral del oprimido.

\section{Marco Referencial}

\section{Antecedentes}

El Teatro del Oprimido ha sido útil en diversas investigaciones internacionales para la intervención social, aportando y confirmando a mi proyecto que los ejercicios y técnicas del método de Augusto Boal son eficaces para promover el pensamiento crítico y reflexivo en los individuos ayudando a mejorar la convivencia entre los grupos y/o comunidades. Teniendo como resultado la transformación social. 
En Palencia, Ibarzabal (2015) realiza un proyecto sobre El teatro del oprimido como herramienta de trabajo del educador social en los centros menores, trabajó con infantes y adolescentes los cuales tenían una inestabilidad emocional ya que vivieron la ausencia de algún referente familiar, entonces, empleando las técnicas de Augusto Boal se obtuvo una respuesta satisfactoria a las necesidades de los individuos de los establecimientos, reflejando motivación, un pensamiento reflexivo y una nueva visión de su realidad.

De la misma forma, Páez (2013) en Madrid-España desarrolló su investigación El Teatro del Oprimido de Augusto Boal como herramienta de intervención social comunitaria, en el Centro Pachamama con un grupo de mujeres donde ellas a partir del método de Boal se sintieron protagonistas de su historia, dueñas de su voz, presente y futuro. Se reconocieron frente al proceso de transformación de sus vidas. Además, los profesionales del Centro quedaron interesados respecto al método por ver resultados satisfactorios.

Además, Ramírez (2016) en la ciudad de Valladolid en España con su trabajo El teatro como herramienta para la intervención social: una aproximación desde el trabajo social, concluyó que el Teatro del Oprimido con sus ejercicios de Teatro Imagen y Teatro Foro son una herramienta que pueden utilizar los profesionales del trabajo social con el fin de realizar una intervención social, sensibilizando los problemas y las necesidades de la población. Teniendo como ventaja la mejora de la autoconfianza, el fomento de la empatía, la compresión, la capacidad de expresión, la creación de historias ficticias donde se proyectan los problemas reales y el desarrollo de la inteligencia emocional, las habilidades sociales y de empoderamiento.

También Manrique y Hernández (2015) de la ciudad de Valladolid en España en su investigación El teatro social, una metodología creativa para el cambio, plantean que a través del Teatro Foro de Augusto Boal puede aportar un cambio a la sociedad y cómo los profesionales del trabajo social pueden incluir en sus actividades diarias éste método para el desarrollo de intervenciones en los grupos y comunidades, teniendo una previa capacitación.

A su vez, Homs (2013) de Barcelona en su proyecto El teatro del oprimido como herramienta socioeducativa para la integración social en el aula 1 de ESO, afirma que el método de Boal permitió a los niños la participación activa, el desarrollo de la personalidad, mejorar la comunicación entre ellos para solucionar los conflictos para teniendo un ambiente 
positivo. Por consiguiente, él recomienda que los docentes deben capacitarse en las técnicas del Teatro del Oprimido para la intervención social del entorno escolar.

En cuanto a Baraúna (2008) en Barcelona sustenta en su tesis doctoral Pedagogía del Oprimido para un teatro social creativo, que la teoría y el método del teatro del oprimido logran que los participantes sientan libertad y puedan ser ellos mismos, manteniendo esa actitud en la vida real. Los sujetos fortalecen sus habilidades sociales con el propósito de obtener un pensamiento crítico y superar la opresión. Comparten con sus semejantes sus historias de vida, encontrándoles solución a las problemáticas que se presenten, alcanzando una reducción de la violencia. A través de éste método se pueden leer y narrar las historias de vida de las personas, gracias a la puesta en escena de sus realidades y encontrar las soluciones de forma creativa. El método del teatro del oprimido de Boal permite fortalecer la competencia comunicativa, se emplea la lectura y escritura, estimula la imaginación y la creatividad, construye un nuevo ser en el mundo con un pensamiento crítico y reflexivo, por medio de los juegos, ejercicios y técnicas.

Las técnicas del teatro del oprimido permiten la estimulación de la creatividad en vista que son "procedimientos creativos que implican acciones educativas llevadas a cabo con grupos comunitarios, con el objeto de favorecer la manifestación de la interacción social, basada en la comunicación, la cooperación, la confianza, la reciprocidad, el respeto mutuo y la responsabilidad" (Baraúna, 2008, p.44).

Con respecto a Escobar y Vallette (2015) de Chile en su investigación Teatro foro como medio para complejizar la mirada del conflicto y las relaciones en el aula, el Teatro Foro concedió a los estudiantes la oportunidad de convertirse en seres reflexivos, activos y participativos. Derribando los esquemas de la educación tradicional. Mejorando la relación con sus compañeros en el aula.

En los antecedentes nacionales, el lenguaje y las habilidades comunicativas apoyan a mi proyecto sustentando que la lectura y la escritura son procesos de significación en todos los ámbitos del ser humano, ya que cumplen una tarea fundamental en la existencia del individuo.

El Ministerio de Educación Nacional de Colombia considera que el lenguaje es mucho más que una herramienta que sirve para transmitir una información, ya que este permite transformar al hombre su experiencia de la realidad natural y social en sentido de y 
conocimiento comunicable. En esta medida el lenguaje se transforma en un sistema de elaboración y producción de la significación. (Parra, 2009, p.9)

El objetivo de los establecimientos de enseñanza es "formar sujetos competentes en una cultura letrada, personas capaces de acudir a la lectura y a la escritura para resolver las necesidades y deseos que surjan en su participación en prácticas reales" (Chois, 2005, p.30). Pero no se cumple cabalmente, una de las tendencias es enseñar a decodificar y a transcribir los signos de la lengua materna sin promover un aprendizaje significativo. Los procesos decodificación y transcripción como eje de la enseñanza de la lectura y la escritura generan un aprendizaje momentáneo y a corto plazo. En palabras de García Márquez:

los colombianos, desde siempre, nos hemos visto como un país de letrados. Tal vez a eso se deba que los programas de bachillerato hagan más énfasis en la literatura que en las otras artes. Pero aparte en la memorización cronológica de autores y obras, a los alumnos no les cultivan el hábito de la lectura, sino que los obligan a leer y a hacer sinopsis de los libros programados. (1995, p.6)

La lectura en las instituciones educativas solo se presenta como un medio de aprendizaje o de compresión para obtener un producto como un examen o un trabajo. No se les muestra como goce, para que la vivan, estén inmersos en ella y despierten pasión, consiguiendo que se exprese un desinterés cuando ven un libro y más, cuando tienen que enfrentar una lectura, su visión hacia ella es una pérdida de tiempo e inutilidad para su vida.

Sin embargo, el Plan Nacional de Lectura y Escritura define lo que se quiere lograr con cada una de las habilidades en los niños. Con respecto a la lectura sostiene que:

implica permitir a los estudiantes vivir la lectura como una experiencia y generar las condiciones para que el acercamiento a los textos no esté atado solo a la comprensión, sino que la lectura se asuma con una posición de receptividad, sensibilidad, apertura y disponibilidad. [...] Reconoce la necesidad de que la escuela le apunte a la formación de un sujeto que busca los textos con razones para leerlos, los comprende, infiere elementos no explícitos, establece relaciones con otros textos y asume una posición frente a lo que en estos encuentra. Se trata de que los estudiantes reconozcan las diferentes funciones que cumple la lectura en la vida diaria, no sólo en lo académico, sino también en el ámbito social. (Plan Nacional de Lectura y Escritura de Educación Inicial, Preescolar, Básica y Media, 2011, p.12)

A pesar de ello los niños presentan temor cuando tienen al frente una página en blanco porque no saben que plasmar. "La página, en blanco. Blanca. Vacía. Llega la angustia. ¡Otra vez! Te da miedo esta situación. Terror. La página en blanco te provoca terror (Cassany, 1995, p.53). Muchas veces es un escrito sobre un tema seleccionado por el docente y bajo 
unas determinaciones estrictas como son la caligrafía y la ortografía. Son necesarias, no obstante, a medida que se incentive el gusto por la escritura se irán aprendiendo y consolidando. Por lo tanto

es necesario resignificar el verbo escribir. Y en concordancia con lo anterior, lo que significa escribir en el sistema escolar. Ello implica la urgente renovación conceptual de parte de los docentes sobre la escritura como proceso y su materialización en nuevas prácticas curriculares y didácticas en las aulas. Esta no es una actividad mecánica como bien dice Vygotsky- y no se reduce a tener dominios caligráficos y ortográficos. Escribir no es copiar. (Plan Nacional de Lectura y Escritura de Educación Inicial, Preescolar, Básica y Media, 2011, p.12)

Por todo lo expuesto anteriormente, esta investigación se propone construir una estrategia pedagógica que articule el teatro y la literatura como forma de abordar la problemática de niños que no leen ni escriben en ningún ámbito y sobre todo en el escolar. A causa de la carencia de una estrategia pertinente para fomentar el gusto por la literatura se intenta despertar ese placer desarrollando su competencia comunicativa eficazmente, brindándoles herramientas para su vida cotidiana y su futuro.

Se plantea el teatro como una mediación pedagógica dado que enseña a escuchar, porque permite aprender a partir de una experiencia personal y profunda, que difícilmente se olvida. La metodología teatral, al integrar la dimensión emocional, abre nuevas perspectivas en el análisis del conflicto, más allá de la óptica estrictamente cognitiva. (Castaño, 2015, p. 22)

El teatro abre un espacio para construir un aprendizaje significativo para que los niños puedan expresarse libremente y fortalecer sus habilidades comunicativas. Considerando que uno de los más grandes problemas "es la falta de espacios en el aula en los cuales los niños tengan la oportunidad de debatir, fijar posición ante los hechos o escribir con sentido sobre situaciones significativas" (Cortes, 2001, p.275). Por consiguiente, es indispensable crear ambientes para desarrollar las potencialidades de los niños, asimismo estimular el gozo por la lectura y la escritura.

Acorde con los antecedentes regionales el teatro se ha utilizado como una estrategia para fomentar las habilidades comunicativas donde los participantes han obtenido resultados satisfactorios, así que brindan solidez a mi investigación para continuar con la labor que otros niños tengan la oportunidad de tener éstos espacios para mejorar su competencia comunicativa. 
Uzcátegui (2004), en su proyecto El teatro como estrategia facilitadora de la lengua en niños con dificultades de aprendizaje, no es discutir sobre las problemáticas de las habilidades comunicativas sino enfrentarlas. Por lo cual, el docente debe comprender la realidad del educando para identificar sus intereses y motivaciones. A fin de poder crear un plan de aprendizaje que le ayude a desarrollar sus habilidades, puesto que, muchos lectores y escritores eficaces han implementado estrategias que no están en los programas escolares. Por ello, la necesidad de vincular el teatro para superar las debilidades en la competencia comunicativa.

La investigación tiene como misión romper con los esquemas de la enseñanza tradicional para lograr que los niños sean conscientes que la lectura y la escritura abre la puerta a nuevos mundos y conocimientos. Como plantea y Deisy Carillo (2012) en su proyecto El teatro como estrategia para incentivar la lectura, el problema es que la escuela sigue con su enseñanza mecanicista y por eso existe aversión, manifestándose la deserción en los colegios. Se debe buscar una estrategia atractiva para que los educandos participen y obtengan conocimientos, pero de manera más amena. Los resultados en la culminación de su propuesta fueron satisfactorios, evidenciando en los educandos mejora en sus habilidades de comprensión expresión.

El teatro como estrategia pedagógica para mejorar la lectura y la escritura en la primera infancia es idóneo puesto que

favorecerá la creatividad en la medida en que promueva en el niño el lado poco convencional de las cosas, el pensamiento crítico y la resolución de problemas. También favorece la fantasía infantil y la creación de mundos posibles a través de la literatura. (Mary Castro, 2008, p. 18)

La mediación pedagógica del teatro los llenará de motivación para que el aprendizaje sea significativo en su vida, apuntando a lo propuesto por el Plan Nacional de Lectura y Escritura: "pensar la lectura como experiencia tiene que ver con asumirla no como algo que sucede externo al lector, sino como algo que le pasa, algo que vive y que le deja una huella" (Pan Nacional de Lectura y Escritura, 2011, p.13). Con respecto a la escritura el teatro los ayudará a que "reconozcan el lugar de la producción textual en la sociedad, en sus dinámicas de relación con otros" (Pan Nacional de Lectura y Escritura, 2011, p.17). El teatro permitirá ver su funcionalidad y utilidad de la lectura y la escritura en la vida diaria brindando un 
espacio para "el encuentro personal del estudiante con sus necesidades, sus emociones y sus propios conocimientos" (Mary Castro, 2008, p.15)

Mary Castro, en su tesis El teatro para incentivar la lectura, obtuvo en los estudiantes de cuarto del colegio Miguel Antonio Caro, una mejora en la comprensión e interpretación de textos por medio de esta estrategia didáctica, dándoles ánimo para acercase a los demás textos del genero del terror. Además, desarrollando su formación integral.

De esta forma el teatro se propone como una estrategia pedagógica y didáctica para "sacar al alumno de su apatía y de su espanto para devolverle el gusto por la vida" (Martínez, 2000, p. 33). Asimismo, conforma "una respuesta educativa a la necesidad de renovar metodologías que optimizaran el proceso de aprendizaje” (García Huidobro, 2004, p. 13).

La competencia comunicativa es fundamental en el niño dado que tiene la necesidad de comunicar sus ideas, emociones y sentimientos por ello se debe desarrollar de la forma más pertinente. Leidy Sánchez (2013) en su tesis El Teatro, actuación creativa, una estrategia para potenciar la competencia comunicativa, utiliza la actuación creativa de Stanislavski para potenciar las habilidades comunicativas de los estudiantes. Este método permite la creatividad, la imaginación, la escritura colectiva, el trabajo en equipo y la interacción. Mediante el mismo los educandos se reconocen como sujetos de conocimiento y de comunicación.

En relación con los antecedentes regionales sobre el Teatro del Oprimido demuestran que han servido para diversos fines. Mostrando que el método de Boal es eficaz para alcanzar diferentes objetivos.

El teatro del oprimido es funcional en el proyecto ya que se puede tener contacto con la realidad social del niño e intentar transformar su realidad. Como expone Maritza Vidal (2005) en su trabajo El teatro del oprimido una herramienta de intervención social este método permite a las personas un pensamiento crítico y reflexivo de su situación. Les permite, finalizando la obra, ver que su realidad puede cambiar y construir simbólicamente un nuevo mundo, con la finalidad de aplicarlo cuando estén en su día a día, volviéndose actores activos de su proceso de cambio, trayéndoles múltiples beneficios individualmente como colectivamente. 
Por lo que se refiere a la tesis Teatro para la memoria: danzantes de pensamientos tuvo el objetivo de "fortalecer procesos de memoria colectiva en jóvenes del pueblo de los Pastos - Resguardo del Gran Cumbal, a partir de talleres de teatro y danzas como estrategia de resistencia ante dinámicas que producen olvido" (Camelo, 2016, p.1). Obteniendo como resultado la creación de un montaje escénico reconocido a nivel local y nacional. El método de Boal

muestra que sus planteamientos son válidos para cualquier temática que responda a la emancipación de los pueblos, en este caso, en un escenario popular que necesitaba involucrar a las nuevas generaciones en la transmisión de sus saberes culturales. Su formulación y desarrollo depende de cada contexto, logrando involucrar cualquier manifestación artística en creaciones colectivas. Ello permitió expresar la historia, los sentires e identidades indígenas del territorio (Camelo, 2016, p.117)

Los antecedentes regionales en torno al libro álbum de Los cerdos de Anthony Browne muestra que el fomento de la literatura en el taller de teatro es adecuado utilizar una de las obras de Anthony Browne porque "creó con sus acuarelas una narrativa fuerte, que mezcla el realismo con toques surrealistas y fantásticos y con efectos visuales humorísticos e ingeniosos" (Pérez, 2016, p.2). Sus temáticas siendo realistas se pueden utilizar de forma eficiente para desarrollar el método del teatro del oprimido, considerando que en su obra literaria hace una crítica de la sociedad y de las relaciones humanas. "El mundo imaginativo de Browne, que le ha merecido el Premio Andersen, es un mundo real, que enfrenta al lector con su propio mundo y, a la vez, le aleja gracias a una mirada idealizada y seductora que nos permite soñar las cosas de diferente manera" (Garralón, Biblioteca Virtual Miguel de Cervantes, 2004).

El cuento seleccionado para trabajar en este proyecto es Los Cerdos, "una obra que muestra el machismo y los prejuicios que existen en muchos hogares y que poco a poco pretendemos hacer desaparecer en la sociedad" (Ortiz, 2015, p.15).El machismo se considera “como un conjunto de creencias, actitudes y conductas que manifiestan la superioridad del hombre sobre la mujer en áreas consideradas importantes para los hombres" (Díaz, 2010, p.35) teniendo como consecuencia que "conductas irresponsables, irrespetuosas y egoístas, [...] colocan a la mujer en una situación de riesgo" (Díaz, 2010, p.37). El género es "el conjunto de construcciones socioculturales que determinan las formas de ser hombres o 
mujeres en un tiempo y una cultura específicos" (Ministerio de Educación Nacional, 2016, p.18). En el cuento se analiza la construcción de género porque siempre se ha aceptado que:

históricamente a los cuerpos, en razón de su sexo, se les ha asignado un papel particular que deben cumplir, asociado directamente al género; así, a las personas que nacen con un cuerpo de hembra se les ha exigido ser mujeres y a las personas que nacen con un cuerpo de macho se les ha exigido ser hombres. (Ministerio de Educación Nacional, 2016, p.18)

Sin tener en cuenta que:

los aprendizajes que se construyen y se estructuran en los diferentes espacios sociales, como la escuela y la familia, entre otros, y no necesariamente corresponde al sexo con el que se nace. Esos aprendizajes hacen que se considere que hay roles específicos y diferenciales que han de ser desempeñados por hombres y mujeres, y que cada persona que esté en una u otra categoría tiene que desarrollarlos obligatoriamente. (Ministerio de Educación, 2016, p.18)

El hombre y la mujer pueden desarrollar las mismas funciones y su labor no se reduce al sexo. Como se presenta en el final del cuento el padre y los hijos pueden realizar las actividades de la casa como cocinar, lavar, planchar y la madre arreglar el carro.

Es una temática que enfrenta al lector con su propio mundo para buscar una solución intentando transformar su realidad social. La relación texto e imagen es fundamental ya que "los párrafos son en su mayoría cortos, buscando que el lector recurra a la ilustración para completar la información. Se consigue de esta manera que ambos sean inseparables y adquieran la misma importancia" (Ortiz, 2015, p.19).

En otra de las publicaciones más relevantes, Willy, el tímido, "la timidez se identifica desde el título hasta sus últimas páginas, el protagonista lucha de sacar de sí este estado que impide sus relaciones personales con normalidad y además lo lleva a tener miedo" (Vela, 2013, p. 31). Vela expone en su trabajo, Análisis de las unidades semánticas en el libroálbum Willy, el tímido, la importancia de la imagen para la comprensión del texto, según la teoría de Faunel Hanán. Por su parte, Voces en el parque "tiene cuatro secciones que corresponden a las visiones de otros tantos personajes que desvelan la historia paralela de cada uno en su contexto familiar y que convergen en una interacción vivencial en un espacio común: el parque" (Arenas, 2012, p.212). Arenas en su investigación Lo narrativo y visual en voces en el parque: una propuesta didáctica interdisciplinar en el aula de secundaria, realizo la relación de literatura con los medios audiovisuales. Demostró que la ilustración 
tiene varios niveles de lectura que complementan el texto. La propuesta tuvo la finalidad de la construcción de una quinta voz en el cuento.

El libro álbum es una herramienta pedagógica en el acercamiento a la literatura como afirma Fajardo (2014) en su artículo "El potencial didáctico del libro-álbum para la educación literaria-intercultural”, no es utilizar la enseñanza memorística para que los educandos den cuenta de las obras teniendo como resultado la repulsión hacia la literatura, por consiguiente, se crea el libro-álbum con el fin de que los niños disfruten el libro, asimilando su mensaje y explorando la lectura visual. El libro-álbum fomenta el interés en cada una de las etapas: prelectura, lectura y poslectura. La educación literaria es esencial en el niño ya que estimulando su imaginación y fantasía es posible comprender críticamente su entorno real, el lenguaje es un medio para transcender y enfrentarse al pensamiento dominante de la sociedad, asimismo, descubrir nuevas realidades e inventar otras. La literatura les ayuda a tomar una posición crítica frente al mundo.

El acercamiento a la literatura no solo incentiva la lectura y escritos de textos, sino que es un medio para la formación del ser, dado que

el niño necesita que se le dé la oportunidad de comprenderse a sí mismo en este mundo complejo con el que tiene que aprender a enfrentarse, precisamente porque su vida, a menudo, le desconcierta. Para poder hacer eso, debemos ayudar al niño a que extraiga un sentido coherente del tumulto de sus sentimientos. Necesita ideas de cómo poner en orden su casa interior y, sobre esta base, poder establecer un orden en su vida en general. Necesita [...] una educación moral que le transmita, sutilmente, las ventajas de una conducta moral, no a través de conceptos éticos abstractos, sino mediante lo que parece tangiblemente correcto y, por ello, lleno de significado para el niño. El niño encuentra este tipo de significado a través de los cuentos de hadas. (Bettelheim, 1997, p. 11)

\section{Marco contextual}

En Colombia existen poblaciones vulnerables en las cuales sus miembros están expuestos a la pobreza, la exclusión, el rechazo, la desigualdad y la violencia. Por ejemplo, en primer lugar, las muertes violentas se registran en los departamentos Arauca, Valle del Cauca, Putumayo, Quindío y Meta. A nivel municipal son Sácama, Briceño, El Castillo, Giraldo y Vista Hermosa. En segundo lugar, la violencia interpersonal se presenta en el archipiélago de San Andrés, Providencia y Santa Catalina, Casanare, Cundinamarca, Quindío y Meta. Y 
los municipios son: Caburayo (Meta), Nariño (Nariño), Subachoque y Cáqueza (Cundinamarca). (Forensis datos para la vida, 2015). Ésta condición deteriora el bienestar y la calidad de vida del ser humano, por ello, lo que se busca es realizar planes de acción para enfrentar esta problemática, para superarla se realizaran "diagnósticos claros sobre su realidad que luego se traduzcan en planes de acción con metas y acciones pertinentes y alcanzables, regulados por labores de permanente seguimiento y evaluación" (Ministerio de Educación Nacional, 2005, p. 5)

La vulnerabilidad se presenta por una situación de desigualdad que es derivada por factores históricos, económicos, culturales y políticos. Teniendo como consecuencia la falta de oportunidad para aprovechar las riquezas del desarrollo humano. Por ello, la Universidad Santo Tomás crea el Centro de Proyección Social Santo Domingo para ofrecerle a los niños de la comunidad, formarse en espacios académicos diferentes para complementar su educación. El C.P.S. está ubicado en la localidad de Chapinero, en la zona definida como Reserva Forestal (Cerros Orientales) y tiene su sede en la calle 65A Nro. 1-34 en el barrio Juan XXIII.

El barrio aparece cuando la población campesina proveniente del departamento de Boyacá es desplazada por la construcción de la Represa del Guavio (proyecto hidroeléctrico de gran magnitud). En 1959, diez familias llegan a Bogotá en busca de un lugar donde vivir, pero dadas sus precarias condiciones económicas deciden tomar los terrenos (invadirlos) y localizarse en ellos de forma ilegal (Plazas, 2005). Con la ayuda de personas como el padre Domingo Eiffo se construyó un jardín infantil y un puesto de salud. Además del padre, otra persona importante en la consolidación del barrio fue María Nelly Bejarano líder comunal, habitante desde los nueve años. Ella, al crecer al mismo tiempo que su barrio, tuvo el deseo de representar a todos sus vecinos para que, algún día fueran reconocidos como un barrio legal en la capital del país. Fue así como Nelly se volvió la representante del barrio y años después la presidenta de la junta comunal. Este cargo que mantuvo por más de quince años, logró múltiples mejoras para el Juan XXIII. Además de ser reconocidos y de obtener servicios básicos, el barrio ganó múltiples premios de dinero gracias a concursos que hizo la alcaldía (en ese entonces de Enrique Peñalosa) a los barrios con comunidades más unidas. Nelly tuvo un rol importante en el desarrollo del barrio y aunque actualmente se fue a vivir a su lugar de origen, delegó este importante papel a otro miembro de la comunidad. (Peláez, 2015) 
El barrio pertenece al estrato 2. Existen tres espacios colectivos de permanencia los cuales tienen carácter simbólico y son: 1. la planada es el espacio de acceso al barrio por su límite oriental y su significado es dual (muerte y juego), dado que allí juegan los niños, pero al mismo tiempo se han dado el mayor número de muertes por violencia social. 2. El salón comunal: es el espacio en donde se reúnen entre ellos mismos y con las personas ajenas que visitan el barrio. 3. La piedra: es el objeto alrededor del cual se desarrollaban las misas al inicio de la conformación del barrio décadas atrás. (Plazas, 2005)

El centro de Proyección Social de Chapinero se organizó a partir del año 2005 por iniciativa de los Frailes del Convento Santo Domingo que han adelantado proyectos de pastoral y fueron los que promovieron la creación de un centro de proyección social. Vale la pena señalar que el C.P.S. Chapinero, ha pasado por tres etapas desde su establecimiento: Fase de diseño y organización, primer semestre de 2005. Fase de prácticas: Consultorio jurídico, reforzamiento escolar y extensión de cátedra primer semestre de 2006. Fase de montaje y desarrollo de proyectos.

Los niños que asisten al C.P.S. están en la edad de siete a trece años. Viven en el barrio Juan XXIII. Sus padres los apoyan para que participen en las actividades que se desarrollan promovidas por los líderes comunales y los profesionales encargados de los ambientes educativos.

\section{Marco teórico-conceptual}

Freire: la lectura como un proceso pedagógico, de integración, libertad y creación de distintas realidades

El lenguaje escrito, de modo similar al lenguaje oral, es una invención social. Cuando una sociedad necesita comunicar a través del tiempo y del espacio y cuando necesita recordar su herencia de ideas y de conocimientos, crea un lenguaje escrito. Esto ocurre cuando las sociedades alcanzan un cierto nivel de complejidad y tamaño. (Ferreiro, 1982, p.17)

La lectura es una interacción entre el lector y el texto, donde son fundamentales las características de los dos. Como plantea Freire (1982), la comprensión y el aprendizaje que obtiene el lector de un texto está ligado fuertemente a sus conocimientos previos. La 
compresión de los individuos sobre la misma lectura puede tener diferentes concepciones y miradas porque depende sus aportes personales al significado. Solo es posible interpretar a través de lo que se conoce.

La lectura no es un proceso mecánico ni rígido. Así, como dice Freire (1998) leer no es pasar los ojos sobre las grafías sin sentido, es encontrar la relación entre ellas para encontrar el mensaje significativo del discurso. El sujeto debe ser crítico, humilde y decidido. Si se quiere aprehender el significado más profundo el lector tendrá que ingresar a la intimidad del texto.

Los lectores de un mismo texto siempre tendrán interpretaciones diferentes, porque sus experiencias son únicas. Además,

La búsqueda de significado es la característica más importante del proceso de lectura y es en el ciclo semántico que todo toma su valor. El significado es construido mientras leemos, pero también es reconstruido ya que debemos reacomodar continuamente nueva información y adaptar nuestro sentido de significado en formación. A lo largo de la lectura de un texto, e incluso, luego, el lector está continuamente reevaluando el significado y reconstruyéndolo en la medida que se obtiene nuevas percepciones. La lectura es, pues, un proceso dinámico muy activo. Los lectores utilizan todos sus esquemas conceptuales cuando tratan de comprender. (Ferreiro, 1982, p.24)

Para Freire, leer implica tener una percepción crítica, interpretación y reescritura de lo leído. La lectura del mundo y la palabra son complementarias encontrándose en un proceso dialéctico. Por consiguiente,

La lectura del mundo no puede ser la lectura de los académicos impuesta a las clases populares. Ni tampoco puede tal lectura reducirse a un ejercicio complaciente de los educadores o educadoras en el cual, comprueba de respeto hacia la cultura popular, callen frente al "saber de experiencia vivida" y se adapten a él. [...]Es precisamente la "lectura del mundo" la que va permitiendo el desciframiento cada vez más crítico de la o de las "situaciones límite". (Freire, 1998, P. 102)

De otro modo, la escritura desempeña una función social, así como dice Cassany (1999) escribir es una forma de lenguaje que permite alcanzar metas. Los humanos somos seres sociales y la mayoría de nuestras acciones son verbales, somos seres más de palabras que de hechos.

La escritura es la forma de producir y transmitir textos en cada situación. Así, "escribir consiste en aprender a utilizar las palabras para que signifiquen, lo que uno pretende que 
signifiquen en cada contexto (Cassany, 1999, p.27) y "aprender a escribir un escrito es aprender a desarrollar la práctica social correspondiente” (Cassany, 2006, p.21)

La escuela debe preparar a los educandos en los procesos de lectura y escritura no solo en el ámbito educativo sino en todos los contextos donde se desenvuelva. Por lo tanto, como plantea Ferreiro (1982) los planteles educativos piensan que los educandos solo aprenden y utilizan la lectura y escritura en el contexto educativo, por ello se concentran en una sola forma de alcanzar el desarrollo de dichas habilidades. Sin percibir como ponen los niños en práctica la competencia comunicativa en su vida diaria.

Al mismo tiempo, la escuela tiene que permitir que los niños sean dueños de sus procesos de lectura y escritura. Teniendo en cuenta que

Los niños conocen ya mucho sobre sí mismos como lectores y escritores. Ya han empezado a hacer suyo el proceso de alfabetización. Con frecuencia, las escuelas tienden a tomar el control y a quitar mucho de ese sentido de propiedad, ese sentido de tener confianza para experimentar con la escritura con muchos propósitos, y ese sentido de confianza para leer y explorar a través de la lectura. Negar las diferencias sociales y culturales y perseguir la uniformidad en las maneras de usar la lectura y la escritura y en las maneras de interacción en relación con el texto escrito, implicaría ignorar un potencial enorme para dar a los niños la oportunidad de llegar a ser "propietarios" de sus actividades de lectura y escritura. Las escuelas, al ignorar las diferencias, negarían a los niños la oportunidad de extender la definición de sí mismos como lectores y escritores, primero en su propia comunidad y después en la sociedad. (Ferreiro, 1982, p. 341)

El sistema educativo debe anular las formas como ven la lectura y la escritura. Siendo la lectura la memorización de contenidos sin sentido y la escritura como la suma de páginas sin ver la calidad de la producción. Por ello, Freire (1998) dice que no se debe insistir en varias lecturas si no hay una comprensión pertinente. No es aprenderlos de memoria ya que no se trata de una fórmula mágica de la palabra escrita.

La lectura y la escritura surgen a partir de los intereses de los educandos para que sean significativas en su vida. Así, Freire (1998) afirma que las habilidades comunicativas se manifiestan en los temas importantes y que se conectan con la experiencia de los alfabetizados. Y no de las palabras o temas impuestos por el docente. 
Leer y escribir son herramientas que nos permiten ingresar al mundo y en su adecuada compresión e interpretación, por esa razón

el aprendizaje de la lectura y de la escritura, por eso mismo, no tendrá significado real si se hace a través de la repetición puramente mecánica de silabas. Ese aprendizaje es válido cuando, simultáneamente con el dominio de la formación de vocablos, el educando va percibiendo el sentido profundo del lenguaje: cuando va percibiendo la solidaridad que existe entre el lenguaje- pensamiento y la realidad, cuya transformación, al exigir nuevas formas de comprensión, plantea también la necesidad de nuevas formas de expresión. (Freire, 1998, p.55)

Las habilidades de lectura y escritura transcienden la decodificación y la transcripción de letras en un papel. Son capacidades que nos ayudan a entender el mundo. Por lo tanto, como dice Freire (1998) antes de leer las palabras se realiza una lectura del mundo. La enseñanza de la lectura y escritura que deje a un lado la lectura y relectura del mundo es pedagógicamente, científicamente y políticamente débil.

Leer y escribir están vinculados con la realidad del ser humano, por lo tanto

No es posible disociar la palabra de la realidad. Hoy me refiero diciendo que hay una lectura del mundo que precede la palabra, y que toda lectura de la palabra implica una relectura del mundo, entonces hay una relación dialéctica entre la lectura del mundo, la lectura de la palabra y la re-lectura del mundo y la "escritura" del mundo. Entiendo por "escribir el mundo", el transformarlo. Inclusive es interesante observar que en la historia del ser humano el ser humano se hizo humano en el momento que comenzó a escribir el mundo, es decir cambiarlo. Entonces, primero escribió el mundo, después hablo el mundo, después escribió la palabra del mundo para poder leer su palabra. (Freire, 2004, p.57)

Específicamente, la lectura y la escritura son habilidades que ayudan a los sujetos a conocer su realidad, hacer parte de ella y transformarla. Para Freire "la alfabetización era ante todo abrir espacios de lucha, en donde los oprimidos se transformasen en sujetos en un proceso de conocimiento transformador de su realidad" (2004, p.11)

\section{Freire: La lectura desde el lenguaje y pensamiento crítico de la liberación}

La función de la lectura no es simplemente decodificar las letras plasmadas en un papel, es ir más allá, es encontrar el vínculo con la realidad para ser consciente de ella, darle sentido y transformarla. De esta forma: 
El auténtico acto de leer es un proceso dialéctico que sintetiza la relación existente entre conocimiento-transformación del mundo y conocimiento-transformación de nosotros mismos. Leer es pronunciar el mundo, es el acto que permite al hombre y a la mujer tomar distancia de su práctica (codificarla) para conocerla críticamente, volviendo a ella para transformarla y transformarse a sí mismos. (Freire, 2004, p.17)

Para que se desarrolle un proceso de transformación en el hombre y su propio mundo se tiene que realizar una lectura crítica de la realidad y que exista una vinculación entre lo que se lee y la realidad.

Es importante que los niños y niñas identifiquen su realidad con el fin de realizar una lectura, un análisis crítico y una transformación a su mundo mediante sus propias soluciones. Permitiendo un conocimiento de sí mismos y su contexto. Así, "el conocimiento de la realidad es indispensable para el conocimiento de sí, y éste para el aumento de aquel conocimiento" (Freire, 2004, p.18).

Todos los individuos tienen habilidades comunicativas, sin embargo, no son desarrolladas eficazmente para utilizarlas de forma idónea en la realidad. "Para Freire el analfabetismo va más allá de la capacidad de leer y escribir un texto escrito. Ser analfabeto significa tener la incapacidad de interpretar y comunicar aspectos de la realidad-social, política, económica, personal...-es decir repetir lo que está establecido" (2008, p.119).

La libertad radica en la construcción de un pensamiento diferente, eso significa ser crítico y reflexivo que permita "condiciones de descubrirse, conquistarse, reflexivamente, como sujeto de su propio destino histórico" (Freire, 2005, p. 11). Como dice Freire, el hombre no crea la posibilidad de libertad sino la hace efectiva y la ejerce.

Los sujetos tienen que hacer un proceso de concienciación para identificar y comprender su realidad. Como Freire plantea en su método pedagógico "dar al hombre la oportunidad de redescubrirse mientras asume reflexivamente el propio proceso en el que él se va descubriendo, manifestando y configurando" (Freire, 2005, p.22).

El individuo es consciente de su realidad cuando tiene una competencia comunicativa pertinente y eficaz. La palabra es el medio para estar inmerso en el mundo y comunicarnos con los otros. La palabra da sentido a nuestra existencia, brinda la oportunidad de construir significados y manifestarlos a los demás. Así que, 
Para asumir responsablemente su misión de hombre, ha de aprender a decir su palabra, porque con ella, se constituye a sí mismo, y a la comunión humana en que él se constituye, instaura el mundo en el que él se humaniza, humanizándolo. Con la palabra el hombre se hace hombre. Al decir su palabra, el hombre asume conscientemente su esencial condición humana. (Freire, 2005, p.17)

La palabra no es abstracta en la vida del ser humano es la llave para la comprensión y la transformación del mundo. Es esencial en el individuo dado que como afirma Freire (2005), la función de la palabra no es solo nombra a las cosas sino las transforma, no es solo pensamiento es praxis.

Incentivar al desarrollo de las habilidades comunicativas ayuda a los niños y niñas con la finalidad de reconocerse en su mundo, ser dueños de su presente y futuro y no ser copias ni esclavos de figuras con discursos incoherentes. Por lo cual, Freire (2005) plantea que la palabra es recuentro de sí mimos. La palabra es personal, creadora no debe ser una repetición ya que se vuelven conciencias sometidas a un dominio por los opresores teniendo como resultado un destino impuesto donde no pueden escapar.

La palabra posibilita la creación de un mundo ideal. Por lo tanto, no es válido decir que aprender a leer y a escribir son procesos mecánicos y rígidos sin sentido, teniendo en cuenta que

La alfabetización no es un juego de palabras, sino la conciencia reflexiva de la cultura, la reconstrucción, crítica del mundo humano, la apertura de nuevos caminos, el proyecto histórico de un mundo común, el coraje de decir su palabra. [...] Aprender a leer es aprender a decir su palabra. Y la palabra humana imita a la palabra divina: es creadora. [...] La palabra se entiende aquí como palabra y acción. Palabra viva y dinámica y no categoría inerte y no exánime. Palabra que dice y transforma el mundo. (Freire, 2005, p. 27)

La lectura y la escritura son habilidades que necesitan ser desarrolladas adecuadamente en el ser humano porque necesita leer su realidad para escribir su historia. Con el fin de manifestarla al mundo. Por lo tanto,

Buscará nuevas palabras, no para coleccionarlas en la memoria sino para decir y escribir su mundo, su pensamiento, para contar su historia. Pensar el mundo es juzgarlo [...] Al comenzar a escribir libremente no copia palabras sino expresa juicios. Éstos de cierta manera, intentan reproducir el movimiento de su propia experiencia; el alfabetizado, al darles forma escrita, va asumiendo gradualmente la conciencia de testigo de una historia de la que sabe autor. En la medida en que se percibe testigo de 
su historia, su conciencia se hace reflexivamente más responsable de esa historia. (Freire, 2005, p. 15)

Hay que mencionar, que la misión de la escuela es primordial si desempeñan bien su papel, ya que su función es como afirma McLaren (2008) educar individuos críticos que se indaguen y discutan de forma activa la relación entre lo teórico-práctico, entre el análisis crítico y el sentido común, entre el aprendizaje y el cambio social.

El objetivo es la formación de una pedagogía crítica en los establecimientos educativos considerando que:

La pedagogía critica no se preocupa solamente de ofrecer a los alumnos y alumnas nuevas formas de pensar de manera crítica y de actuar con autoridad en las aulas, conscientes de su papel de agentes de cambio; también se preocupa de proporcionar a los alumnos y alumnas las habilidades y los conocimientos necesarios para que amplíen las capacidades, ya sea para cuestionar las suposiciones y los mitos fuertemente asentados que legitiman los hábitos sociales más arcaicos y restrictivos (que estructuran todos los aspectos de la sociedad) o para asumir su responsabilidad de intervenir en el mundo que habitan. (McLaren, 2008, p. 18)

Antes de la formación en la pedagogía crítica se ha debido tener una alfabetización crítica, teniendo en cuenta que lo segundo es el resultado de lo primero. Entonces, la alfabetización crítica es como afirma McLaren (2008) es un proceso critico que se utiliza de forma oral o escrita como medio de expresión y transformación en la vida de cada uno y de los individuos que nos rodean.

Como afirma Giroux (1998) la alfabetización critica lucha por darle significado a la vida de las personas reafirmando su existencia y recobrando sus voces para que puedan contar sus propias historias. También, como plantea MacLaren (2008) la pedagogía y la alfabetización critica tiene por objetivo que los educandos narren sus propias historias. Contar la historia es un modo inseparable de supervivencia emocional.

Por medio de las historias de los estudiantes se pueden fomentar el pensamiento crítico el cual se desea obtener con el fin que ellos puedan ser agentes de cambio en sus grupos, comunidades y sociedad, por tanto, hay que incentivar al estudio de las experiencias personales de los niños, niñas y jóvenes.

El método de la alfabetización critica, que consiste en formular preguntas, fue desarrollado por Paulo Freire (1973) y por los pedagogos críticos desde la década de 
los años veinte, con la Escuela de Frankfurt de teoría critica, cuyo propósito inicial era la alfabetización de los alumnos y alumnas adultos. Este método guía a los alumnos y alumnas de cualquier edad, con cualquier experiencia y de cualquier nivel de capacidad para que basen su aprendizaje en la experiencia personal, de un modo que fomenta la reflexión crítica y la participación activa. (McLaren, 2008, p. 281)

Las experiencias son hechos valiosos en la vida de los individuos, pero sino se comprenden adecuadamente no pueden leer, ni interpretar su mundo y menos a la sociedad que pertenecen. Como dice Giroux (1998) la creación de las experiencias ofrece dar sentido y expresión a su voz poniendo en práctica las facultades críticas.

\section{Boal: Teatro del oprimido}

Paulo Freire educador y escritor (1921-1997) inspiro con sus libros La pedagogía del oprimido (1970) y La pedagogía de la esperanza, un reencuentro con la pedagogía del oprimido (1993) a Augusto Boal escritor, dramaturgo y director de teatro (1931-2009) para la creación de la teoría y el método del Teatro del Oprimido.

El teatro durante mucho tiempo ha tenido diversos significados, cada vez que se escucha el concepto se viene a la mente un espacio físico, un espectáculo donde se ven luces, se escuchan diferentes sonidos y están presentes actores interpretando una obra. No obstante, para Augusto Boal dramaturgo, escritor y director de teatro

El teatro es la primera invención humana, la que permite y promueve todos los demás inventos. El teatro nace cuando el ser humano descubre que puede observarse a sí mismo y, a partir de ese descubrimiento, empieza a inventar otras maneras de obrar. Descubre que puede mirarse en el acto de mirar; mirarse en acción, mirarse en situación. Mirándose, comprende lo que es, descubre lo que no es e imagina lo que puede llegar a ser. Comprende en donde está, descubre donde no está e imagina a donde puede ir. Se crea una composición tripartita: el yo-observador, el yo -en situación y el -posible (el no-yo, el Otro) (Boal, 2004, p.25).

El teatro no es solamente para los profesionales sino para todos los seres humanos, la gran diferencia es que ellos exploran su vocación y los demás no se dan la oportunidad. Pero somos parte de él, ya que según Boal el ser humano es teatro. Por ello, es necesario trabajarlo porque está en la esencia de cada sujeto. Es pertinente utilizarlo en el ámbito educativo con 
el propósito que los niños se conozcan y puedan desarrollar otra visión del mundo, obteniendo un pensamiento crítico para afrontar las problemáticas de una sociedad tan compleja como la nuestra, participando en ella y transformándola.

Por esta razón, la estrategia pedagógica se fundamenta en el Teatro del Oprimido el cual

es un sistema de ejercicios físicos, juegos estéticos y técnicas especiales cuyo objetivo es restaurar y restituir a su justo valor la condición humana, que hace de la actividad teatral un instrumento eficaz para la compresión y la búsqueda de soluciones a problemas sociales e intersubjetivos. [...] El teatro del oprimido se desarrolla en cuatro aspectos fundamentales: artístico, educativo, político-social y terapéutico. (Boal, 2005, p.28)

Lo interesante del Teatro del Oprimido no es comprender o interpretar un rol determinado, sino que los sujetos entiendan su vida y asímismo puedan encontrar sus propias soluciones a los problemas del día a día, haciendo una construcción simbólica de ellas en escena y luego la transporten a su vida cotidiana. "El teatro del oprimido crea espacios de libertad donde la gente pueda dar rienda suelta a sus recuerdos, emociones, imaginación, pensar en el pasado, en el presente e inventar su futuro en lugar de sentarse a esperarlo de brazos cruzados" (Boal, 2002 p.14).

El teatro del oprimido es un método de cuatro etapas: conocer el cuerpo, tornar el cuerpo expresivo, el teatro como lenguaje y el teatro como discurso. La primera es una serie de ejercicios que permiten que el individuo conozca su cuerpo y sea consciente de sus debilidades, fortalezas y limitaciones. La segunda, es una secuencia de juegos donde el cuerpo se manifiesta de otras formas que no son habituales. La tercera, se desarrolla el lenguaje vivo y presente y no como un producto culminado que muestra un pasado, en ésta etapa se emplea la dramaturgia simultánea, el teatro imagen y el teatro foro. Y la última, son formas sencillas (teatro periodístico, teatro invisible, teatro fotonovela, quiebra de represión, teatro-mito, teatro-juicio, y rituales y máscaras) para presentar espectáculos según sean las necesidades de los actores-espectadores.

La meta del Teatro del Oprimido no es llegar a un equilibrio tranquilizador, sino al desequilibrio que conduce a la acción. Su objetivo es dinamizar. Esto se consigue a través de la acción concreta, en escena: ¡el acto de trasformar es transformador! 
Transformando la escena, me transformo. Es en ese sentido en que podemos decir que la catarsis del Teatro del Oprimido es purificadora: nos purifica de nuestros bloqueos y ensancha los atajos que queremos tomar para transformar nuestra vida. (Boal, 2005, p. 95)

El Teatro del Oprimido es una teoría y método innovador que se sale de los esquemas del teatro convencional, ya que se basa en tres grandes transgresores como son: todos pueden participar en la escena empleando el poder, el espectáculo teatral y la vida real se concentran todos pueden ingresar en el mundo teatral.

Además, el teatro del Oprimido se representa por medio de un árbol estético:

Tiene raíces, tronco, ramas y copas. Sus raíces están clavadas en la tierra fértil de la Ética y la Solidaridad, que son su savia y el factor primero para la invención de sociedades no opresivas. En esta tierra coexisten el remanente del instinto depredador animal y el avance humanístico. En la tierra, vemos la miseria del mundo; en las copas, el sol de la mañana. (Boal, 2012, p. 256) [...] La ética y la solidaridad, en forma estática son la savia que alimenta el Gran Árbol del TO y viajan por las arterias axiales de la Palabra, de la Imagen y del Sonido, transitan por los Juegos, metáfora de la realidad, e inician el proceso de despojarnos de la basura cultural que nos rodea, estimulando la creatividad de los participantes. El proceso practico estético se inicia en el tronco del Árbol con los juegos lúdicos, que, al contrario de los juegos de azar, tienen reglas fijas, pero exigen creatividad, de la misma forma que la sociedad tiene leyes pero exige libertad. Sin leyes no existe la vida social: sin leyes no existe la vida. (Boal, 2012, p. 260)

El teatro del Oprimido es una oportunidad para realizar ensayos concretos de cómo se actuaría en la realidad, pero no acaba cuando se termina el taller, el ensayo o la sesión se debe poner en práctica en la realidad para intervenir y transformarla. No es suficiente conocer la realidad hay que cambiarla.

Las habilidades comunicativas se incentivan a partir del Teatro del Oprimido con la finalidad que los educandos tengan herramientas siendo actores de su vida y no simples espectadores. Viendo como los opresores los reprimen y los explotan. Obligando a recibir “mensajes imperativos de los medios de comunicación, de la cátedra, del podio, del pulpito y todos los sargentos sin pensar en refutarlos, ¡Sin entender siquiera! (Boal, 2012, p.93)

Por eso, el lenguaje no solamente se adquiere sino se desarrolla. El lenguaje se convierte en un arma de poder, dado que 
Las palabras son símbolos y, para que un símbolo exista, es necesario el acuerdo de los interlocutores. Como casi todo en la vida social, también las palabras se vuelven objetos de encarnizadas luchas. La etimología muestra la correlación de fuerzas de la sociedad en el momento en el que fabrico una palabra para revelar -u ocultar- una verdad. La semántica se convierte en un campo de batalla en el que todas las fuerzas en conflicto buscan, en cada palabra, atribuirle el sentido que más le convenga. La lucha semántica es la lucha por el Poder. (Boal, 2012, p.101)

No es suficiente que los niños conozcan los procesos básicos y mecánicos de la lectura y la escritura, es necesario transcender para que puedan realizar grandes transformaciones a su realidad como Freire (2004) afirma que leer y escribir son fáciles sin embargo tener la capacidad de leer y pronunciar el mundo se necesitan de capacidades superiores, así siendo necesario que los sujetos asuman el papel creativo y pensante de su realidad. Las habilidades comunicativas permiten que los individuos puedan compartir sus mundos y referirse a ellos, así como dice Habermas (2003) los sujetos están en la capacidad de referirse a más de un mundo, no obstante, en la comunicación con el otro puede entenderse entre sí sobre algún aspecto de los dos mundos y de esta forma compartirlo. La acción comunicativa se basa en los fragmentos de vida de los sujetos en la interacción.

Los actos de habla son aceptables cuando el oyente puede tomar una postura frente a lo que recibe del hablante, de ahí que Austin distingue tres actos que son decir algo (locucionario), hacer diciendo algo (ilocucionario) y causar algo mediante lo que se hace diciendo algo (perlocucionario).

Así, que la acción comunicativa son las habilidades que tiene el ser humano como: hablar, escuchar, leer y escribir, las cuales permiten acercarnos a la realidad y participar en ella.

Los educandos deben ver la lectura como una reflexión crítica y no como la decodificación de unas letras sin sentido, así como dice Freire que aprender las letras no es desarrollar la capacidad reflexiva. Ellos tienen el derecho de desarrollar una competencia eficaz a fin de no ser oprimidos por las figuras de poder. Para no quedarse en la visión que

El acto de leer (como reflexión crítica) aparece como si fuese el derecho exclusivo de unos pocos, de aquellos que pueden desarrollar las funciones propias de la cabeza: los que leen y escriben las letras de la dominación, los que deciden qué, cómo y para quién se debe leer el mundo (Freire, 2004, p.18) 
Por otro lado, el Teatro del Oprimido trabaja en sus ejercicios la creatividad y la imaginación. Al igual que el método de Stanislavski (1947) donde despierta estas potencialidades poniendo en situación al personaje, dando la posibilidad que los actores piensen, actúen y hablen como los personajes en una determinada situación problemática. La diferencia es que en el Teatro del Oprimido no son actores sino individuos que desde sus experiencias de opresión pueden imaginar y proponer soluciones creativas reales para sus problemáticas. Considerando que la creatividad

es sinónimo de «pensamiento disidente», es decir de «rompimiento de esquemas». «Creativa» es la mente que trabaja continuamente, siempre dispuesta a hacer preguntas, a descubrir problemas allí donde los demás encuentran respuestas satisfactorias, capaz de juicios autónomos e independientes (incluso de los del padre, de la sociedad), que rechaza la codificación, que recicla objetos y conceptos, sin dejarse influir por los conformistas. Todas estas cualidades se manifiestan en el proceso creativo. (Rodari, 1995, p.150)

\section{Browne: el libro álbum, una estrategia pedagógica lúdica}

El libro álbum Los cerdos de Anthony Browne despierta el placer y el gozo por la literatura ya que se da una lectura no convencional. Dado que, "el álbum además de ser un libro, y por encima del libro que es, es algo más, es la plasmación de una forma de comunicación, basada en una forma de representación, que provoca un nuevo "modo de leer" (Banco del libroGRETEL, 2010, p. 187).

Los cerdos de Anthony Browne pertenece a la literatura infantil concediéndole al niño conocer las situaciones problemáticas de la sociedad a la cual pertenece y reconocer los valores que debe conservar o adquirir. Así que, "desde tempranas historias de la Literatura infantil se contempla la posibilidad de que esta sea un medio para transmitir un sistema de valores con el que se pretende modelar o condicionar al hombre" (Acosta, 2011, p. 36) y "tiene la función de introducir al niño a su sociedad, presentarle y sumergirlo, a través de metáforas e imágenes, en el mundo social al que pertenece” (Acosta, 2011, p. 38).

Es un cuento de placer porque es atractivo por su estructura y su modo de leer. Y es un texto de goce ya que le plantea una problemática al lector que desacomoda su tranquilidad y lo pone a pensar en su realidad. Así, como define Barthes, 
Texto de placer: el que contenta, colma, da euforia; provienen de la cultura, no rompe con ella y está ligado a una práctica confortable de la lectura. Texto de goce: el que pone en estado de pérdida, desacomoda, hace vacilar los fundamentos históricos, culturales, psicológicos del lector, la congruencia de sus gustos, de sus valores y de sus recuerdos, pone en crisis su relación con el lenguaje. (2007, p. 25)

A partir del placer y el goce se puede decir que un niño como dice Rodari (1973) lee porque quiere saber qué sucede, como termina el texto, su mensaje, la enseñanza no porque se lo han ordenado. Lee por su propia iniciativa. Es crear espacios donde pueda surgir el gusto por la lectura con el cual no nace. Sin embargo, si está en un ambiente burocrático (copias, resúmenes, análisis gramaticales) se desarrolla la técnica de la lectura, pero no despertará el interés por ella. Los niños aprenderán el proceso mecánico de la lectura y lo realizara por obligación.

El libro siendo una obra literaria transmite hechos maravillosos los cuales son medios para disfrutar de nuestra imaginación dejándonos sorprender.

El objeto libro, cualquier libro, especialmente en el caso de la obra literaria, es, equivale a una caja escénica: un artefacto que, al abrirse y leerse, da lugar a una representación ficticia por la que deambulan distintos personajes tensando los hilos de una determinada dramaturgia narratológica, a la que podemos clasificar en géneros, y a la que cada cual, como lector, asiste y otorga voz y acción. También creo que álbum, como libro que es, alberga una caja escénica muy singular entre sus cubiertas, que permite a sus lectores asistir a las más variadas representaciones, algunas incluso muy lúdicas y circenses, llenas de efectos especiales y sorpresas. (Banco del libroGRETEL, 2010, p. 187)

El libro-álbum tiene dos lecturas que son el texto y la imagen. Las dos están apoyadas para la comprensión o deducción de su mensaje. Así, como afirma Banco del libro-GRETEL (2010) es necesaria la ilustración y lo escrito para construir a dúo lo que no se dice explícitamente.

En la escuela solo se enseña una forma de leer que es la decodificación de las letras en un papel. Pero no se enseña los diversos modos de lectura que existen, visto que todo lo que nos rodea lo podemos leer. Por lo tanto, como afirma Banco del libro- GRETEL (2010) leer es interpretar todos los signos como: visuales, gestuales, fónicos, tonales, olfativos entre otros. 
De otro modo, la imagen en el libro-álbum desempeña una función fundamental en la vida del niño, es decir

Una de las funciones de las representaciones, graficas o lúdicas, dirigidas a la más tierna infancia consiste en familiarizar progresivamente al niño con la representación de la realidad porque, cognitivamente, percibir la realidad o percibir su representación son dos cosas bien distintas, en la que el niño desarrolla habilidades y experiencias sumamente básicas para su desarrollo y sociabilización. (Banco del libro- GRETEL, 2010, p.193)

Por otro lado, la lectura del libro-álbum se convierte en un juego donde el niño empleara los dos tipos de lectura (textual y visual) descubriendo lo que le quieren decir las imágenes y las palabras conjuntamente. Participado activamente de la lectura. Así, como dice Banco del libro- GRETEL (2010) es un juego con el fin de ocultar y revelar haciendo de forma abierta una invitación al lector a participar lúdicamente en la formulación de hipótesis mediante los indicios.

La propuesta del libro-álbum es sorprender a los niños y las niñas. Es la estrategia que cautiva al lector. Contiene "narraciones donde predomina la revelación gradual de una sorpresa. Si bien la mayoría de los relatos se basan en la inclusión de elementos sorpresivos destinados a procurar el interés y la atención de los lectores”. (Banco del libro- GRETEL, 2010, p.117)

El efecto sorpresivo no se basa solo en las palabras. Es la función del complemento de la imagen y el texto. Son dos componentes que actúan en conjunto. Como afirma Banco del libro- GRETEL (2010) buscar en forma lúdica lo que no está explícito y se va revelando poco a poco es similar al juego de palabras como es la adivinanza.

Por consiguiente, se vuelve atractivo para los niños porque la lectura del libro-álbum y en este caso de Los Cerdos de Anthony Browne es un juego donde su posición de lector es activa "Para un niño el mundo está lleno de objetos misteriosos, de acontecimientos incomprensibles, de figuras indescifrables [...] De aquí el placer de probar de forma desinteresada, por juego, o casi por entretenimiento, la emoción de la búsqueda y la sorpresa” (Rodari, 1995, p.48)

Es un juego la lectura del libro-álbum debido al desciframiento de lo que está oculto, la formulación de predicciones e hipótesis y su correspondiente verificación. Para luego 
dejarse sorprender por el final. Siendo un juego despierta el placer y el gozo por el acercamiento a la literatura.

La expectativa y la sorpresa son importantes en el aprendizaje de literatura, especialmente para los lectores inexpertos. Los niños aprenden a rellenar vacíos, a realizar predicciones, y, en el proceso de re-lectura, a confirmar o corregir dichas predicciones para poder lograr un cierre. [...]Si el final sorprendente codifica la información que se ha ocultado y revelado en la narración permitirá que se activen los procesos cognitivos implicados en la lectura, como la deducción, la inferencia y llenar los vacíos. Estos juegos invitan al lector a experimentar una emoción muy poderosa: la sorpresa, que es solamente uno de los muchos placeres que puede ofrecer la literatura. (Banco del libro- GRETEL, 2010, p. 132-134)

Por otra parte, la comprensión de la obra literaria puede provocar efectos retóricos como también propone Barthes (1964) en su libro La retórica de la imagen. El lector reacciona por una vinculación entre el mensaje de la lectura y su realidad. Como es:

Analogía: cuando entre la relación del significado y significante (o cuando entre lo vivido por mí y lo expresado por otro) goza de un alto grado de similitud.

Apropiación: Cuando se pueden establecer nexos de similitud entre lo nuevo percibido y lo conocido por la experiencia.

Extrañamiento: Cuando las disimilitudes son superiores a las similitudes (y ello estimula nuestra curiosidad)

Refutación: Cuando nuestra experiencia se rehúsa aceptar la insólita propuesta ajena. (Banco del libro- GRETEL, 2010, p. 133)

El cuento seleccionado el Libro de los Cerdos, "una obra que muestra el machismo y los prejuicios que existen en muchos hogares y que poco a poco pretendemos hacer desaparecer en la sociedad" (Ortiz, 2015, p.15).El machismo se considera "como un conjunto de creencias, actitudes y conductas que manifiestan la superioridad del hombre sobre la mujer en áreas consideradas importantes para los hombres" (Díaz, 2010, p.35) teniendo como consecuencia que "conductas irresponsables, irrespetuosas y egoístas, [...] colocan a la mujer en una situación de riesgo" (Díaz, 2010, p.37). El género es "el conjunto de construcciones socioculturales que determinan las formas de ser hombres o mujeres en un tiempo y una cultura específicos” (Ministerio de Educación Nacional, 2016, p.18). En el cuento se analiza la construcción de género porque siempre se ha aceptado que:

históricamente a los cuerpos, en razón de su sexo, se les ha asignado un papel particular que deben cumplir, asociado directamente al género; así, a las personas que nacen con un cuerpo de hembra se les ha exigido ser mujeres y a las personas 
que nacen con un cuerpo de macho se les ha exigido ser hombres. (Ministerio de Educación Nacional, 2016, p.18)

Sin tener en cuenta que:

los aprendizajes que se construyen y se estructuran en los diferentes espacios sociales, como la escuela y la familia, entre otros, y no necesariamente corresponde al sexo con el que se nace. Esos aprendizajes hacen que se considere que hay roles específicos y diferenciales que han de ser desempeñados por hombres y mujeres, y que cada persona que esté en una u otra categoría tiene que desarrollarlos obligatoriamente. (Ministerio de Educación, 2016, p.18)

El hombre y la mujer pueden desarrollar las mismas funciones y su labor no se reduce al sexo. Como se presenta en el final del cuento el padre y los hijos pueden realizar las actividades de la casa como cocinar, lavar, planchar y la madre arreglar el carro.

Es una temática que enfrenta al lector con su propio mundo para buscar una solución intentando transformar su realidad social. La relación texto e imagen es fundamental ya que “los párrafos son en su mayoría cortos, buscando que el lector recurra a la ilustración para completar la información. Se consigue de esta manera que ambos sean inseparables y adquieran la misma importancia" (Ortiz, 2015, p.19).

\section{Metodología}

El proyecto tiene un paradigma cualitativo con un tipo de investigación acción participativa, así como lo define el Doctor Chica Cañas (2010) los participantes diagnostican las situaciones problemáticas y las acciones con el propósito de transformar la realidad. Los participantes son los beneficiarios de la investigación y son con los mismos sujetos que ha de hacerse la formulación del diseño, la recopilación de la información y su respectiva interpretación. Por lo cual se cumple en este proyecto porque los niños identificaron la problemática del machismo en sus vidas, construyeron soluciones simbólicas a través de la creación colectiva del guión y puesta en escena, de esta forma transformaron su realidad. Además, la participación fue activa, comprometida, eficiente y decisiva. También, tiene un enfoque etnográfico ya que se trabajó un problema común desde las experiencias personales y familiares de cada uno de los niños reconociéndose en el otro. Utilizando técnicas e instrumentos como son: la selección de la muestra, la observación participativa y observación de campo, las grabaciones sonoras de vídeo y la fotografía. 


\section{Selección de la muestra}

Los niños que se seleccionaron fueron niños a partir de los siete años, los cuales ya tenían conocimientos de lectura y escritura con el fin de fortalecer éstas habilidades comunicativas. Además, dependía de sus intereses hacía el teatro y la literatura, unos educandos deseaban mejorar su expresión corporal y oral, participar en una experiencia teatral; otros querían fortalecer la lectura en voz alta, la comprensión e interpretación de los textos; y mejorar la composición escrita.

Los participantes del proceso fueron treinta niños de siete a trece años. Prevaleciendo el género femenino que el masculino. Cómo era un grupo grande y de diversas edades, se establecieron cinco grupos focales de seis integrantes por edades

\section{La observación participativa y observación de campo}

La investigadora convivio con los niños del Centro de proyección Social Santo Domingo durante cuatro meses, llevando el registro de lo que observaba (comportamientos, actitudes, desarrollo de las actividades, debilidades, fortalezas y aspectos por mejorar) en todos los talleres a través del diario de campo. (Anexo 3)

\section{Grabaciones sonoras de vídeo y la fotografía}

En cada taller se hizo un registro fotográfico y de video sobre los ejercicios de lectura, escritura, improvisaciones, trabajo de expresión corporal, juegos de imaginación, creatividad, concentración, activación de sentidos, etc.

Por otro lado, la propuesta se desarrolló con diecinueve niños de 7 a 13 años del Centro de Proyección Social Santo Domingo se localiza en la localidad de Chapinero en la zona definida como Reserva Forestal (Cerros Orientales) y tiene su sede en el barrio Juan XXIII en la calle 65A Nro. 1-34. Como docente e investigadora diseñé diez talleres desde la pedagogía de la liberación de Freire y del Teatro del Oprimido de Boal. Cada taller tiene dos etapas:

1. Motivación, en esta fase se realizaron los ejercicios de calentamiento 
2. Exploración del conocimiento o autoconocimiento, son las actividades de literatura y teatro (lectura de texto e imágenes del cuento, formulación de palabras generadoras, análisis de la lectura, la puesta en escena de las problemáticas, creación del guión teatral a partir de la construcción escénica de posibles soluciones y presentación de la obra)

\section{Aspectos legales}

\section{Componente ético}

El día 16 de febrero se realizó una reunión con los padres de familia de los niños que estaban interesados en participar en el proyecto, en el barrio Juan XXIII a las 7:00 p.m. Se les explico el objetivo, la duración de los talleres, el producto final y se les solicito la autorización para el registro de fotografías y vídeos de los menores por medio del consentimiento informado, siguiendo con la firma del documento mencionado anteriormente. (Ver Anexo 2)

\section{Plan de Análisis}

Para el plan de análisis además de los instrumentos y técnicas mencionadas anteriormente se utilizó para la recolección de información la ficha general, los talleres, carpetas de trabajo, creación colectiva y representación de la obra de teatro.

\section{Ficha general}

El día 10 de febrero del año en curso se realizó una encuesta a los padres de familia, dónde se llegó a la conclusión que los progenitores tienen la intención de apoyarla participación de los niños en las actividades desarrolladas por el Centro de Proyección Social teniendo razones como: la mejora en el rendimiento académico, las relaciones interpersonales, utilidad en el tiempo y proyección del futuro.

Por otro lado, en el documento quedó consignado que el tiempo libre de los menores les gusta jugar, dibujar, pintar cantar, bailar y patinar. Sus aspiraciones son: ser chef, futbolistas, profesoras, doctoras, traductoras, cantantes, bailarinas, abogados, ingenieros, pilotos, fotógrafos, diseñadoras y policías.

Por otra parte, el gran porcentaje de los niños tienen acceso a la seguridad social. Sus familias no se componen por personas desmovilizadas ni desplazadas. La mayoría viven en un inquilinato, en arriendo y tienen acceso a los servicios de agua, alcantarillado, luz, gas, telefonía móvil, internet y recolección de desechos. (Ver Anexo 1)

\section{Talleres}


Se desarrollaron diez talleres desde el día 17 de febrero hasta el día 19 de mayo. Cumpliendo con las dos etapas: motivación y exploración del conocimiento. Con duración de noventa minutos cada sesión.

\section{Carpetas de trabajo}

Cada estudiante llevaba una carpeta de los trabajos realizados en las actividades propuestas, sobre su percepción a sí mismos, su familia y su barrio temáticas derivadas de la lectura literaria del libro de los Cerdos. Además, el resumen y la comprensión del texto, el planteamiento de nuevos finales, la posición frente al mensaje del libro y las ideas para la construcción colectiva del guion.

\section{Creación colectiva y representación de la obra}

Los niños escribieron por grupos las ideas para la creación colectiva del guión, plantearon el título, nuevos personajes, espacios y complementaron el final, manifestando que el mensaje del cuento debía permanecer en la obra de teatro. Entonces se realizó la adaptación teatral sin alterar la enseñanza y la crítica social del texto.

Para la representación de la obra de teatro los estudiantes planearon por escrito su personaje: vestuario y maquillaje. Y en escena crearon el ambiente.

\section{Unidad de análisis}

Los niños que participaron en el proyecto fueron diecinueve, se organizaron por grupos focales para el proceso y las recurrencias fueron habilidades comunicativas, expresión corporal, creatividad, pensamiento crítico, imaginación, sueños, improvisación, creación de personajes, reflexión crítica, catarsis purificadora entre otras.

\section{Cronograma}

\section{Análisis de Resultados}

\section{Capítulo 1}

\subsection{Encontrándonos con la literatura y el teatro}

Objetivo 1: Caracterizar la población y su respectivo contexto para identificar la realidad sociocultural. 
Para el desarrollo del objetivo 1 se aplicaron cuatro talleres: el piloto, ¿Quién soy?, compartiendo nuestro mundo familiar y describiendo la imagen de mi barrio con el fin de

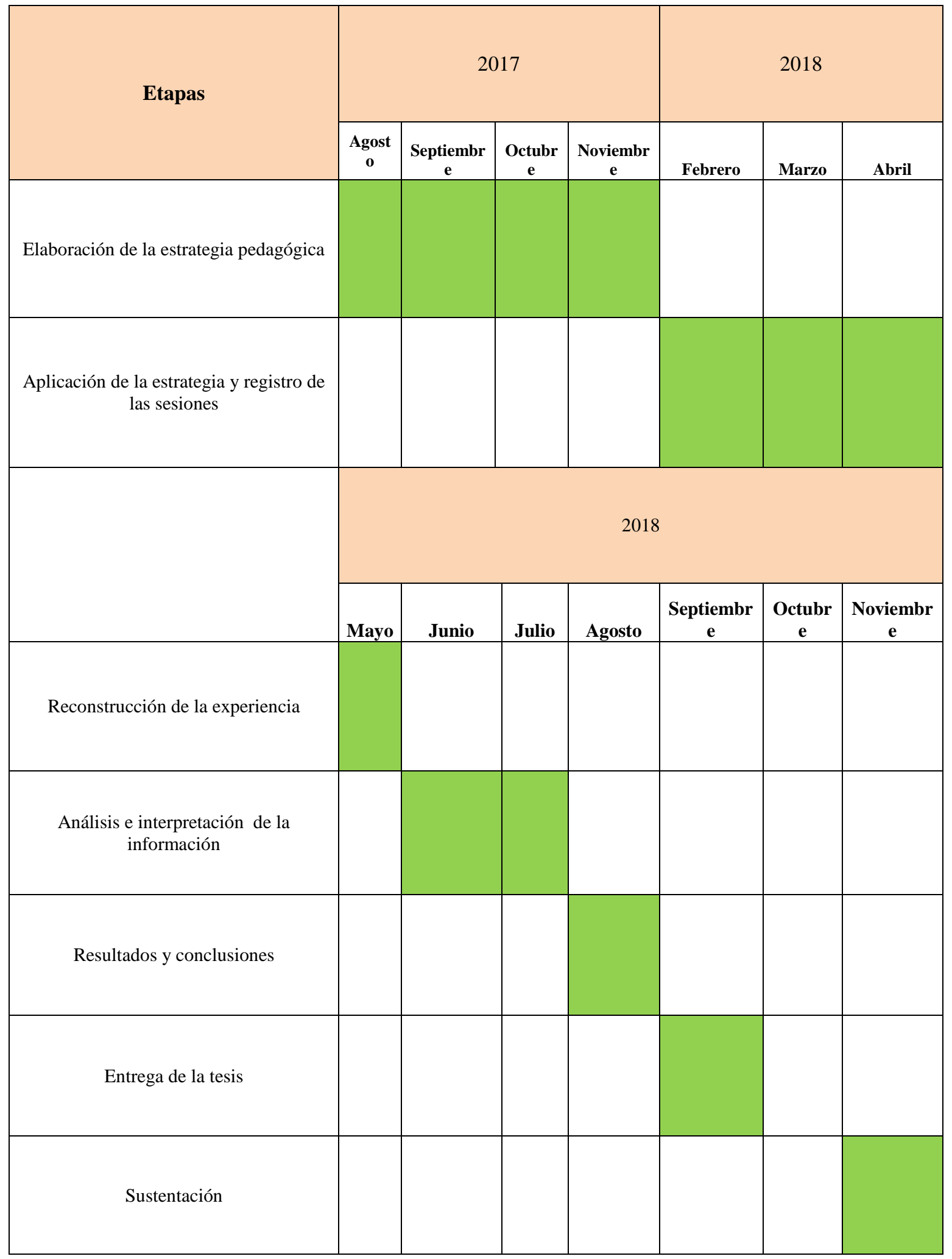


reconocer los ámbitos de cada niño. En el taller piloto se realizó un diagnóstico de la población con la cual se trabajó para observar debilidades y fortalezas. En el taller 1 ¿Quién soy? Los niños se identificaron con el otro, en el taller 2 leyeron y narraron su experiencia familiar, por último, en el taller 3 manifestaron la imagen de su barrio a través de diversas expresiones como escrita, teatral y artística.

\section{Taller piloto}

\begin{tabular}{|c|c|c|c|}
\hline Objetivo & Actividades & Materiales & Tiempo \\
\hline $\begin{array}{l}\text { Conocer e } \\
\text { interactuar con el } \\
\text { grupo }\end{array}$ & $\begin{array}{l}\text { 1.Presentación de la } \\
\text { docente y los estudiantes } \\
\text { ( } 20 \text { minutos) } \\
\text { 2.Juego de mímica: un } \\
\text { compañero le dice al oído } \\
\text { a otro qué debe } \\
\text { interpretar un animal o } \\
\text { una actividad. (20 } \\
\text { minutos) } \\
\text { 3.Explicación de la } \\
\text { bitácora } \\
\text { 4.Los estudiantes deben } \\
\text { escribir en la bitácora } \\
\text { qué expectativas tienen } \\
\text { acerca del taller. (20 } \\
\text { minutos) }\end{array}$ & $\begin{array}{ll}\text { - } & \text { Bitácora } \\
\text { - } & \text { Hojas } \\
\text { - } & \text { Lápices. }\end{array}$ & $\begin{array}{l}\text { Tiempo: } 60 \\
\text { minutos }\end{array}$ \\
\hline
\end{tabular}

El día 17 de febrero asistieron al taller treinta niños de seis a catorce años. Los más pequeños no sabían leer ni escribir, pero querían participar en el proceso, estaban más inclinados por teatro. Se inició con una dinámica de integración la cual consistía que cada uno se presentaba cuando recibiera una pelota y así sucesivamente. La mayoría de niños demostraban timidez y tenían una inadecuada expresión oral. Como lo evidencia la niña A.Q. en su escrito: 


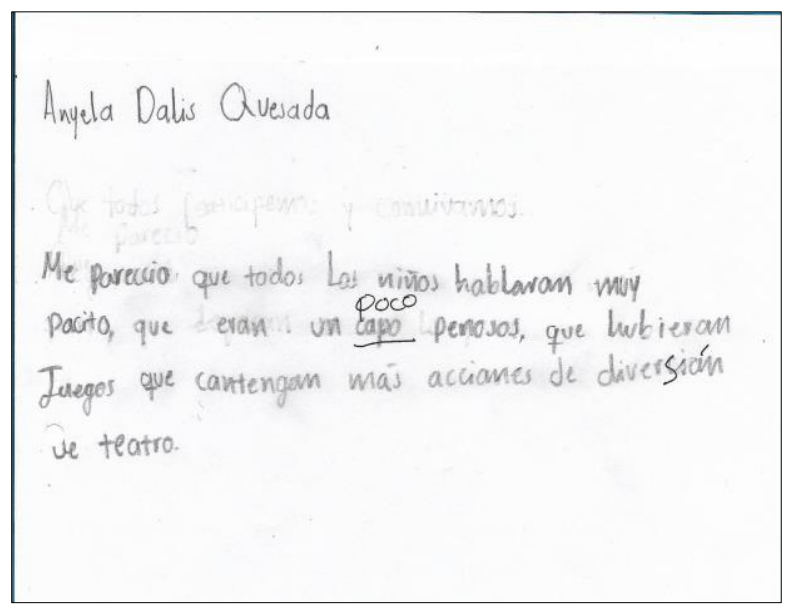

Objetivo 1. Taller piloto. Escritura sobre la conclusión del taller.

La segunda actividad fue una mímica, algunos niños intentaban realizar el ejercicio, pero les faltaba desarrollar un poco más su expresión corporal. Por ejemplo, como vemos en la foto de la niña A.V.

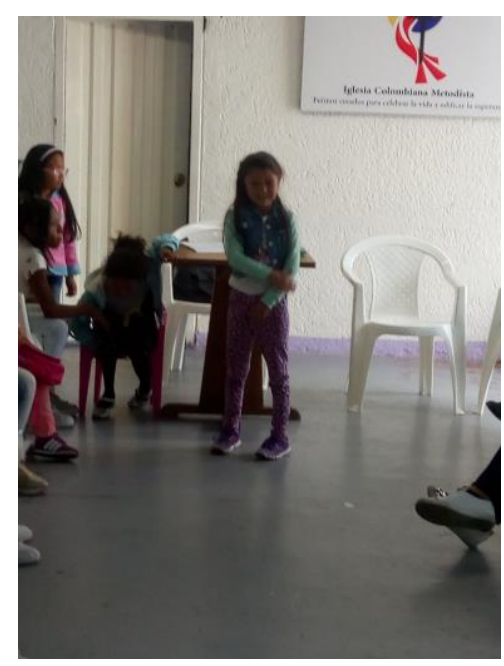

Objetivo 1. Taller piloto. Juego de mímica.

La expresión corporal según Boal es importante trabajarla porque el individuo es consciente de cada músculo, parte y movimiento de su cuerpo para entrar en una acción determinada y tener control sobre la actividad propuesta.

La última actividad fue la escritura sobre las expectativas que cada uno tenía acerca de los talleres de literatura y teatro. La mayoría de los niños tienen sus expectativas en el teatro, 
por ejemplo, la niña V.M. quiere participar en una obra de teatro y tener el rol de ladrona o el personaje que le sea asignado.

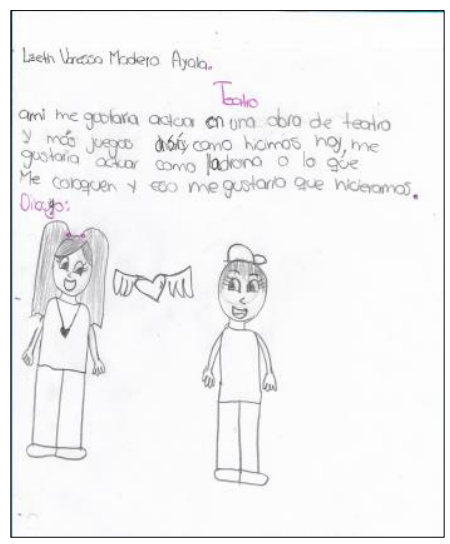

Objetivo 1. Taller piloto. Conclusión del taller.

Las recurrencias del taller fueron la timidez, la diversión, la actuación y los personajes. La recurrencia diferente: lectura y escritura. Se clasificaron en dos grandes categorías como teatro y competencia comunicativa. En teatro: la actuación, los personajes y la diversión; en competencia comunicativa: la lectura y la escritura.

El teatro está creado para decir algo o transmitir un mensaje, los niños quieren actuar, divertirse y construir un personaje, para lograrlo deben fomentar el desarrollo de sus habilidades comunicativas como la lectura y escritura porque el fundamento del teatro es el lenguaje, el cual se convierte en un arma de poder ya que:

Las palabras son símbolos y, para que un símbolo exista, es necesario el acuerdo de los interlocutores. Como casi todo en la vida social, también las palabras se vuelven objetos de encarnizadas luchas. La etimología muestra la correlación de fuerzas de la sociedad en el momento en el que fabrico una palabra para revelar -u ocultar- una verdad. La semántica se convierte en un campo de batalla en el que todas las fuerzas en conflicto buscan, en cada palabra, atribuirle el sentido que más le convenga. La lucha semántica es la lucha por el Poder. (Boal, 2012, p.101)

Así que el teatro como estrategia pedagógica los motiva para contribuir con su competencia comunicativa y participar en el proceso teatral y literario.

\section{Taller No. 1}

¿Quién soy? 


\begin{tabular}{|c|c|c|c|}
\hline Objetivo & Actividades & Materiales & Tiempo \\
\hline $\begin{array}{l}\text { Objetivo general: } \\
\text { Identificar la } \\
\text { realidad social- } \\
\text { cultual de los niños y } \\
\text { niñas a partir del } \\
\text { método del Teatro } \\
\text { del Oprimido. } \\
\text { Objetivo } \\
\text { específico: } \\
\text { Conocerla } \\
\text { personalidad de los } \\
\text { niños y las niñas. }\end{array}$ & $\begin{array}{l}\text { Etapa 1: Motivación (20 } \\
\text { minutos) } \\
\text { El espejo simple } \\
\text { Etapa 2: Exploración } \\
\text { conocimiento } \\
\text { autoconocimiento } \\
\text { minutos) } \\
\text { 1.Creación sobre las portadas } \\
\text { de las bitácoras } \\
\text { 2.Dibujo de sí mismos para } \\
\text { reconocerse } \\
\text { 3.Creación de una imagen } \\
\text { colectiva utilizando } \\
\text { expresión corporal }\end{array}$ & $\begin{array}{ll}\text { - Hojas } \\
\text { - } \quad \text { Lápices. }\end{array}$ & 90 minutos \\
\hline
\end{tabular}

El día 24 de febrero asistieron al taller veintinueve niños. Primero se realizó un ejercicio de expresión corporal de Teatro Imagen. El espejo consiste en reproducir todos los movimientos y gestos faciales de la persona que está al frente. Reconocerse en el otro.

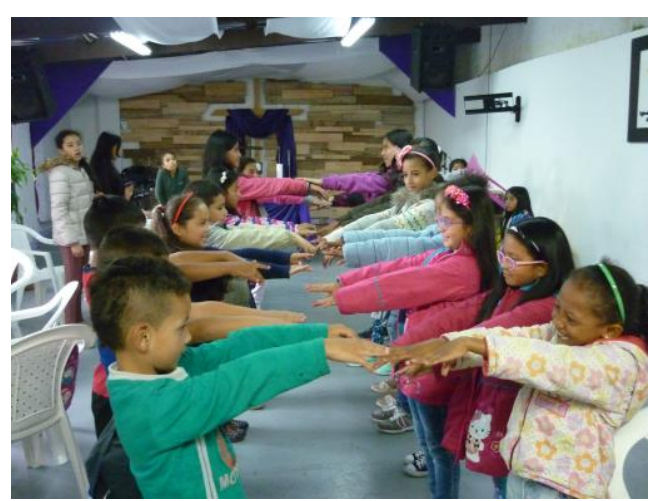

Objetivo1. Taller 1. Ejercicio El espejo

El espejo simple se basa en realizar 
Dos filas de participantes, cada uno mirando fijamente a la persona que tiene enfrente. Las personas de la fila A son designadas como sujetos, y las de la fila B como imágenes. El ejercicio comienza y cada sujeto inicia una serie de movimientos y de expresiones faciales, en cámara lenta, que debe reproducir en sus mínimos detalles la imagen que está enfrente.

El sujeto no debe considerarse enemigo de la imagen: no se trata de una competición, de hacer movimientos bruscos, imposibles de seguir: se trata, por el contrario, de buscar la perfecta sincronización de movimientos y la mayor exactitud en la reproducción de los gestos del sujeto por parte de la imagen. La exactitud y la sincronización deben ser de tal orden que un observador exterior no sea capaz de distinguir quién origina los movimientos y quién los reproduce. Es importante que los movimientos sean lentos (para que la imagen pueda reproducirlos y preverlos) y también continuos. Es igualmente importante que se preste atención a los mínimos detalles, sea de todo el cuerpo, sea de la fisionomía. (Boal, 2012, p.228)

La segunda actividad fue el dibujo de sí mismos para reconocerse. Los niños se dibujaron felices, rodeados de naturaleza y otros plasmaron sus sueños, las niñas desean ser: patinadoras, bailarinas, porristas y cantantes; así como la niña A. F lo demuestra en el siguiente dibujo

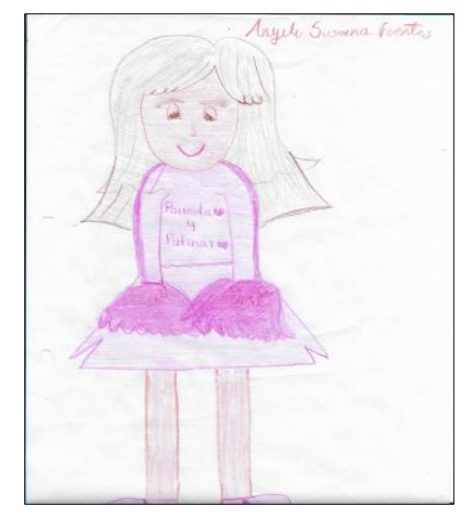

Objetivo 1. Taller 1. Dibujo sobre sí mismo para reconocerse.

Llegando a la conclusión que sus aspiraciones son deportivas y artísticas.

Finalizando el taller los estudiantes crearon una flor colectiva con sus cuerpos 


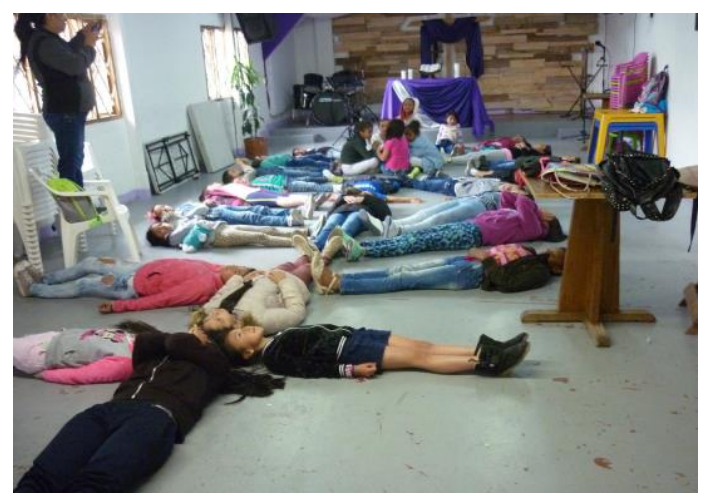

Objetivo 1. Taller 1. Creación colectiva de una imagen.

Recurrencias en el taller dibujo, felicidad, sueños y expresión corporal. Teniendo como gran categoría el lenguaje visual: expresión corporal y artística.

Los niños comenzaron a ejercitar su expresión corporal con los ejercicios del espejo y la creación de la flor colectiva. Siendo conscientes que existe otro lenguaje con el cual pueden expresar sus sentimientos, pensamientos, deseos ya que

Los ejercicios desarrollan la capacidad de observación mediante el diálogo visual entre dos o más personas. [..] El teatro imagen tiende a desarrollar el lenguaje visual y la introducción de cualquier otro lenguaje (la palabra, por ejemplo) (Boal, 2012, p.227)

Los niños entablan un diálogo a través de su expresión corporal reflejando lo que piensan a través de sus movimientos y gestos faciales. "Nos buscamos a otros mismos en los otros, que a su vez se buscan en nosotros" (Boal, 2012, p. 234)

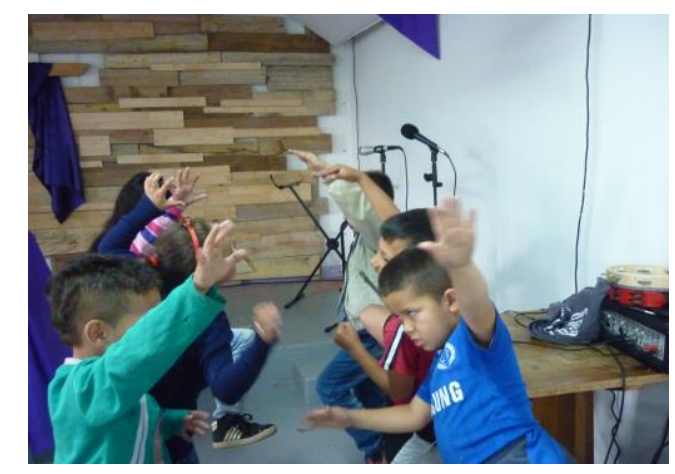

Objetivo 1.Taller 1. El espejo.

Los niños expresan sus emociones a través del cuerpo pensando en cada parte de la flor, como se sienten los pétalos, el tallo, las hojas: 


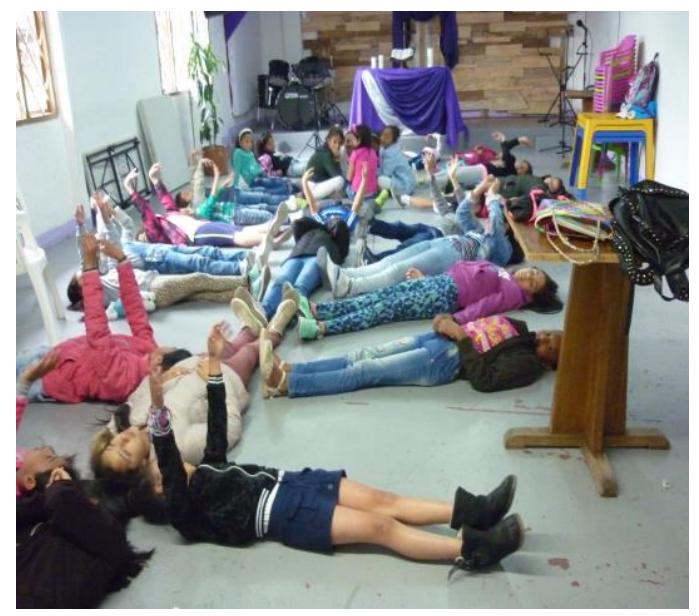

Objetivo1. Taller 1. Creación colectiva de una imagen.

Por otra parte, en la expresión artística los niños manifestaron sus sentimientos y aspiraciones.

La niña M.O. se dibuja feliz en medio de la naturaleza y en la otra parte muestra su sueño de ser cantante. No recurre al lenguaje escrito porque con el visual es suficiente demostrar lo que siente y piensa.

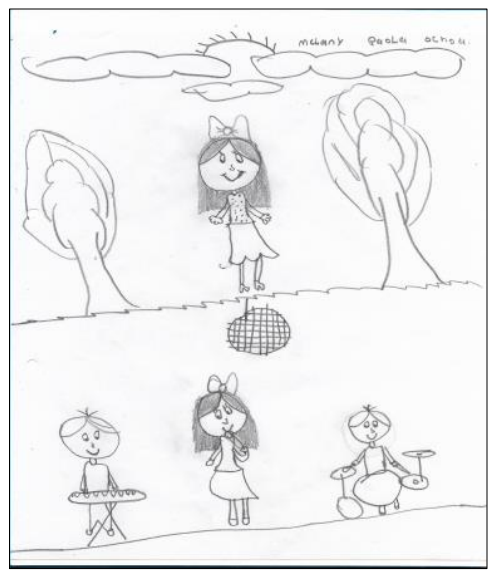

Objetivo 1. Taller No. 1

El teatro permite otro lenguaje para transmitir mensajes y comunicarnos con los demás. Estimulando el desarrollo de diversas capacidades para la formación de un ser integral que es una de las metas del teatro.

\section{Taller No. 2}


Compartiendo nuestro mundo familiar

\begin{tabular}{|c|c|c|c|}
\hline Objetivo & Actividades & Materiales & Tiempo \\
\hline $\begin{array}{l}\text { Objetivo general: } \\
\text { Identificar la } \\
\text { realidad social- } \\
\text { cultual de los niños } \\
\text { y niñas a partir del } \\
\text { método del Teatro } \\
\text { del Oprimido. } \\
\text { Objetivo } \\
\text { específico: } \\
\text { Reconocer el ámbito } \\
\text { familiar de los niños } \\
\text { y niñas. }\end{array}$ & $\begin{array}{l}\text { Etapa 1: Motivación (20 } \\
\text { minutos) } \\
\text { 1.Presentación del libro Los } \\
\text { cerdos de Anthony Browne } \\
\text { 2.Lectura de la imagen de la } \\
\text { portada del libro y } \\
\text { planteamiento de hipótesis } \\
\text { Etapa 2: Exploración } \\
\text { conocimiento } \\
\text { autoconocimiento } \\
\text { minutos) } \\
\text { 1.Dibujo sobre la familia } \\
\text { 2.Improvisación con el tema } \\
\text { de la familia }\end{array}$ & $\begin{array}{ll}\text { - } & \text { El cuento } \\
\text { - } & \text { La bitácora } \\
\text { - } & \text { Marcadores } \\
\text { - Hojas } \\
\text { - Lápices. }\end{array}$ & 90 minutos \\
\hline
\end{tabular}

El día 3 de marzo asistieron veintidós niños al taller. Comienza la sesión con la presentación del libro Los Cerdos de Anthony Browne, luego con la lectura visual de la imagen de la portada, la descripción y formulación de hipótesis.

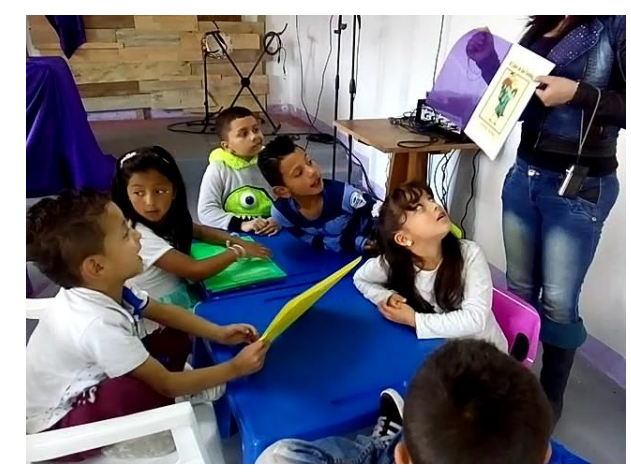

Objetivo 1. Taller 2. Lectura visual de la portada del libro. 
Después los niños dibujan a sus familias y escriben las características.

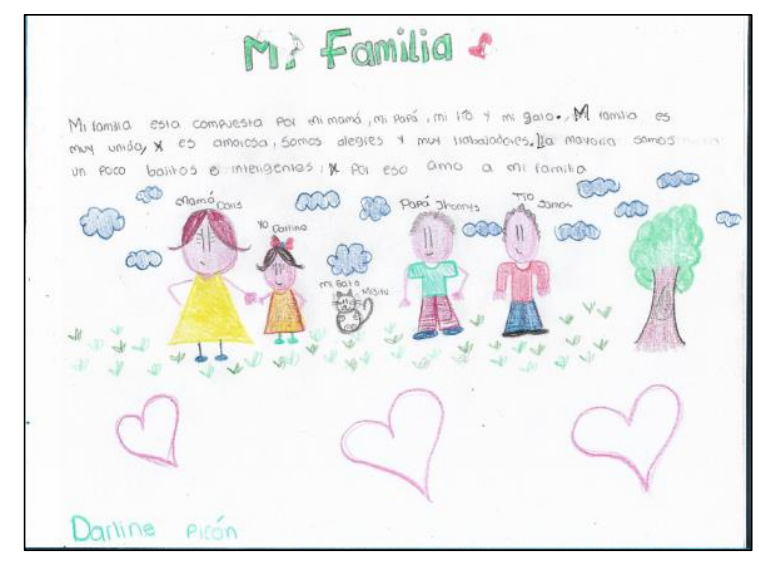

Objetivo 1. Taller 2. Dibujo sobre la familia.

Por último. Los cinco grupos realizan las improvisaciones sobre la temática que se está trabajando en el taller

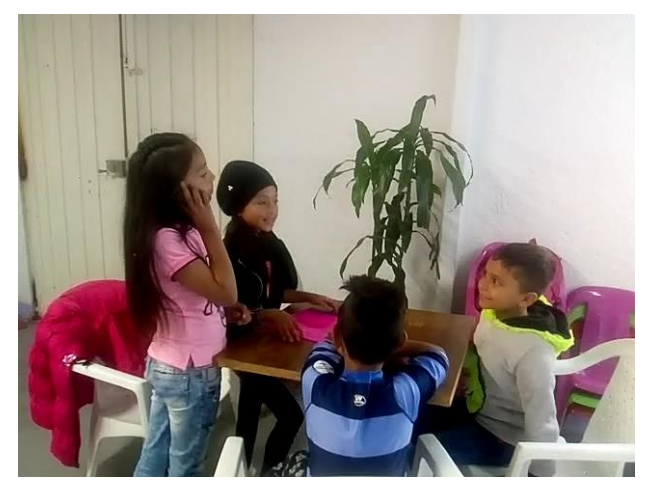

Objetivo 1. Taller 2. Improvisación sobre la familia.

Las recurrencias son cariño, amabilidad, unión, amor, felicidad, conflicto, solución, dibujo y escritura. Emergen dos categorías la primera expresión artística y escrita: familia con las subcategorías: cariño, amabilidad, unión, responsabilidad, amor y felicidad; la segunda, improvisación: conflicto y solución.

En los dibujos creados por los niños se identifican cuatro tipos de familia, la primera: padres e hijos, la segunda: padres e hijo, la tercera: madre e hijos, la cuarta: padres, hijos y otros familiares. Sin embargo, así existan diferentes clases de familias los niños plasman sentimientos positivos que los manifiestan por medio de la expresión artística y escrita porque 
esa es la lectura que hacen de su mundo, pasando a otro nivel de lectura y escritura, como plantea Freire

Saber leer y escribir es relativamente fácil, pero tener la capacidad para desarrollar un constante proceso cognoscitivo para pronunciar el mundo, requiere de un esfuerzo mayor, es necesario que los hombres y las mujeres asuman un papel creativo y pensante ante su realidad. (Freire, 2004, p. 17)

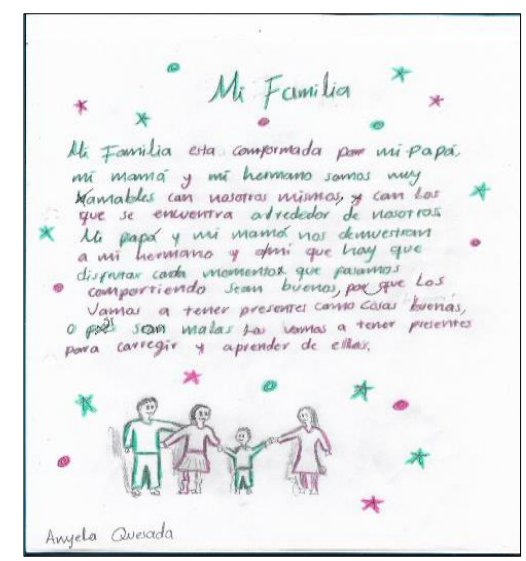

Objetivo 1. Taller No. 2. Escritura y dibujo sobre la familia.

La niña A.Q. expresa la enseñanza de sus padres: disfrutar de la vida y aprender de ella cuando sea necesario. Emplea la lectura y la escritura desde otra visión, lee su contexto familiar y escribe para exteriorizar su realidad, por ejemplo: el comportamiento de su familia, las características y las enseñanzas que la hacen una mejor persona.

Por otro lado, en la improvisación sobre la familia los niños presentan los conflictos y su respectiva solución. Un conflicto que surgió fue: el problema de convivencia en el colegio de dos hermanos. La solución: la docente los lleva a la rectoría y llama a la madre. Ella se lleva a sus hijos y soluciona el problema a través del diálogo. 


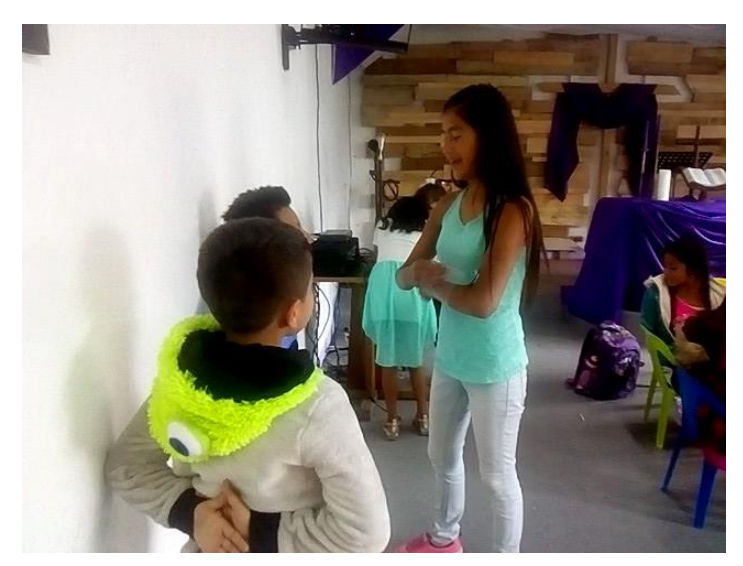

Objetivo 1. Taller 2. Improvisación sobre la familia.

Éste primer ejercicio presenta la meta del Teatro del Oprimido que es

restaurar y restituir a su justo valor la condición humana, que hace de la actividad teatral un instrumento eficaz para la compresión y la búsqueda de soluciones a problemas sociales e intersubjetivos. (Boal, 2005, p.28)

Los niños plantearon el problema de convivencia ya que se había presentado en el salón con unos compañeros, pero ellos lo adaptaron para su ejercicio de improvisación, comprendieron el conflicto y buscaron una oportuna solución. Siendo un ensayo para poner en práctica en la realidad y mostrando su pensamiento frente a estos sucesos.

\section{Taller No. 3}

\section{Describiendo la imagen de mi barrio}

\begin{tabular}{|l|l|l|l|}
\hline \multicolumn{1}{|c|}{ Objetivo } & \multicolumn{1}{|c|}{ Actividades } & Materiales & Tiempo \\
\hline Objetivo & Etapa 1: Motivación (20 & $\bullet$ El cuento & 90 \\
general: & minutos) & - Marcadores & minutos \\
Identificar la & Juego de la pelota & \\
realidad social- & Futbol, baloncesto, voleibol o & $\bullet$ Lápices. & \\
cultual de los & pimpón. Dos equipos jugaran un & \\
niños y niñas a & partido sin usar ninguna pelota, & \\
partir del método & sino actuando como si tuviesen & \\
del Teatro del & una. La docente -árbitro del & \\
Oprimido. & partido- puede observar si el & \\
\end{tabular}




\begin{tabular}{|l|l|}
\hline Objetivo & $\begin{array}{l}\text { movimiento imaginario de la } \\
\text { pelota coincide con los } \\
\text { específico: } \\
\text { Reconocer el } \\
\text { contexto donde } \\
\text { corrigiéndolos si fuese necesario. } \\
\text { viven los niños y } \\
\text { niñas. }\end{array} \mid \begin{array}{l}\text { Etapa 2012, p.245) } \\
\text { conocimiento 2: Exploración } \\
\text { autoconocimiento (70 minutos) } \\
\text { 1.Lectura de la primera página } \\
\text { (imagen y texto) de los cuentos de } \\
\text { Los Cerdos. } \\
\text { 2.Comprensión de la lectura } \\
\text { 3.Dibujo y escritura sobre el } \\
\text { barrio } \\
\text { 4.Improvisación sobre el barrio }\end{array}$ \\
\end{tabular} \mid

El día 10 de marzo asistieron veinte cuatro niños al taller. La primera actividad fue un ejercicio de imaginación, el juego de la pelota imaginaria. Los niños escogían un deporte por grupo e iniciaba la actividad.

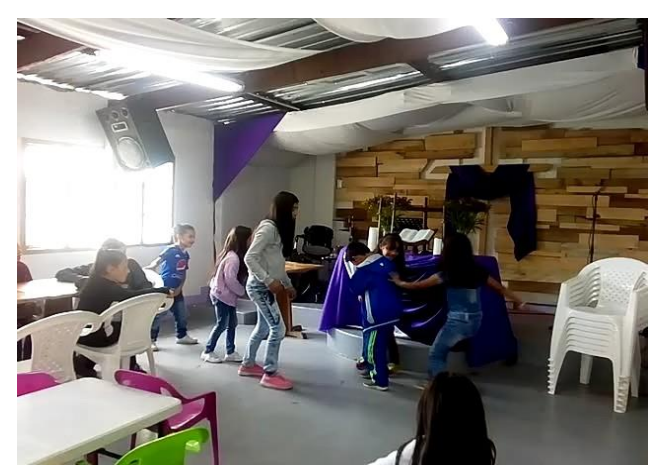

Objetivo 1. Taller 3. Juego de la pelota imaginaria.

La segunda actividad fue la lectura y compresión de la primera página del libro Los cerdos de Anthony Browne. 


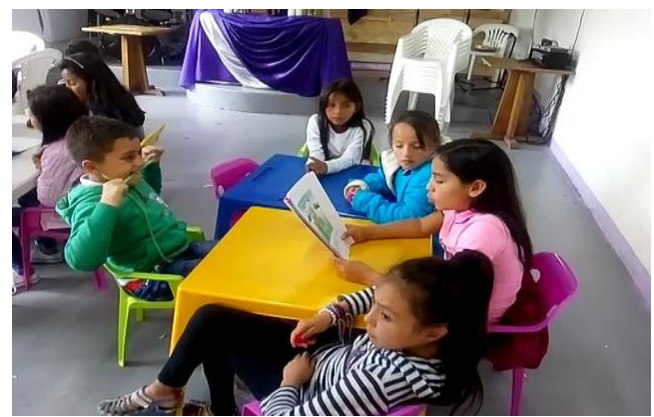

Objetivo 1. Taller 3. Lectura y comprensión.

Luego, dibujo y escritura sobre el barrio.

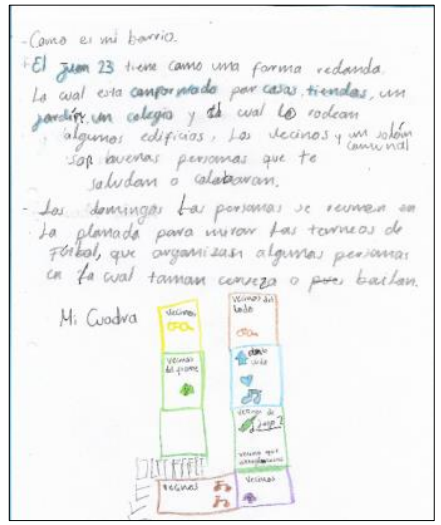

Objetivo 1. Taller 3. Dibujo y escritura sobre el barrio.

Por último, las improvisaciones con el tema que se estaba tratando en el taller.

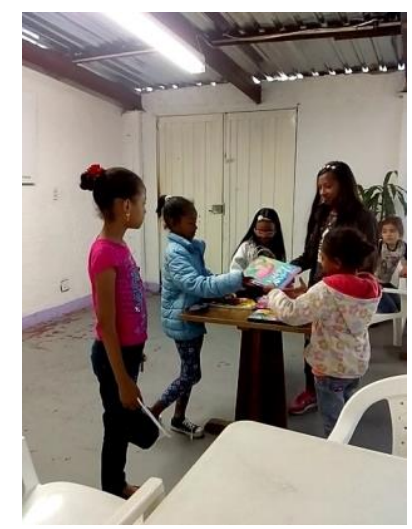

Objetivo 1. Taller 3. Improvisación sobre el barrio.

Recurrencias del taller imaginación, dibujo, lectura, escritura, descripción e improvisación. Las recurrencias se clasifican en dos categorías, la primera, expresión artística y habilidades comunicativas: dibujo, lectura, escritura y descripción. Teatro: imaginación e improvisación. 
En la primera categoría los niños hicieron una lectura y escritura de su entorno, específicamente de su barrio. La niña D.P. describió la estructura de su barrio "en mi barrio también hay muchos callejones, donde viven varias personas, también tiene calles muy empinadas, pero otras no tanto, por ejemplo, la planada que queda en la parte de arriba del barrio y ese lugar nos podemos encontrar con algunos edificios, colegios y jardines". Además, escribe cuál es su posición frente al lugar donde vive "mi barrio también es alegre y divertido porque hay un parque. Salimos a jugar por la noche, en mi barrio hay personas amables y serviciales"

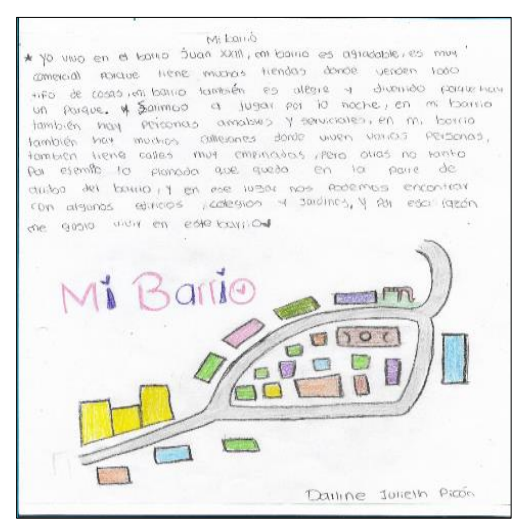

Objetivo 1. Taller 3. Dibujo y escritura sobre el barrio.

En este ejercicio los niños realizaron la lectura y escritura de su entorno desde su realidad, mostrando su posición crítica respecto a él, así como dice Freire "la lectura y la escritura de las palabras pasan por la lectura del mundo. Leer el mundo es un acto anterior a la lectura de la palabra (1998, P. 75).

Los niños leen y escriben su entorno desde la felicidad, rescatando todo lo positivo que existe dentro de lo negativo. No importa que las calles sean empinadas o esté lleno de callejones lo que interesa es la amabilidad y solidaridad que hay entre vecinos. El punto de encuentro donde se reúne toda la comunidad para llevar a cabo diversos eventos. Por ello,

La lectura del mundo no puede ser la lectura de los académicos impuesta a las clases populares. Ni tampoco puede tal lectura reducirse a un ejercicio complaciente de los educadores o educadoras en el cual, comprueba de respeto hacia la cultura popular, callen frente al "saber de experiencia vivida" y se adapten a él. [...]Es precisamente la "lectura del mundo" la que va permitiendo 
el desciframiento cada vez más crítico de la o de las "situaciones límite”. (Freire, 1998, P. 102)

La lectura y escritura deben superar el nivel básico en el que se han reducido estas habilidades comunicativas. Hay que seguir explorando otros niveles para que los niños logren una posición crítica de su mundo.

Por otra parte, el teatro propone ejercicios de imagen como la actividad de la pelota imaginaria que fortalece el lenguaje no verbal

cuando se trabaja con imágenes no hay que intentar entender el sentido de cada imagen, captar su significado exacto, sino sentir esas imágenes, dejar vagar nuestra imaginación, nuestros recuerdos: el sentido de una imagen es la imagen misma. La imagen es un lenguaje (Boal, 2012, p.242)

Uno de los grupos escogió baloncesto y se evidencia como la niña utilizo su cuerpo para ser la cesta y el niño que estaba jugando se dejó llevar por su imaginación y emoción.

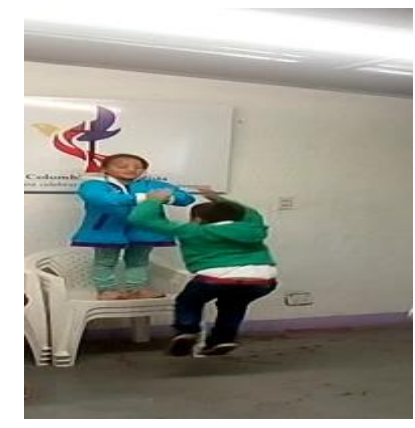

Objetivo 1. Taller 3. Juego de la pelota

En la improvisacion 10 n ninos representaron ras escenas cotıaianas del barrio en lugares como la panadería, la papelería, el almacén de ropa y el salón comunal donde realizan eventos como jugar bingo. Los niños han mejorado su capacidad creativa y expresiva, utilizan recursos que tengan a su alrededor para presentar sus improvisaciones. Por ejemplo, en la escena de la panadería, los niños organizaron las mesas de los clientes y de las panaderas, creando el ambiente. Cuando entran en acción utilizan la plastilina como si fuera la masa del pan, recurriendo a la imaginación. 


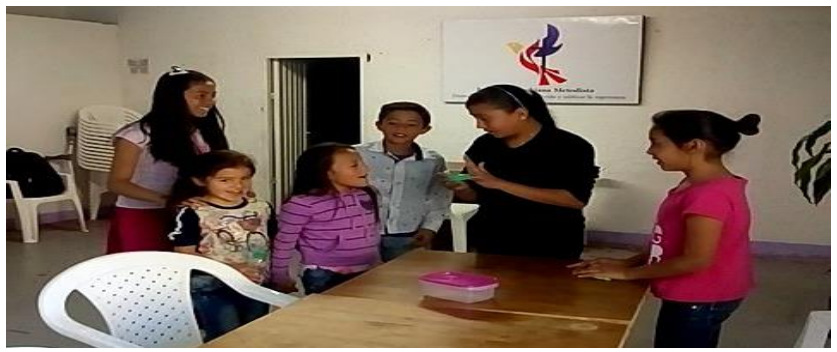

Objetivo 1. Taller 3. Improvisación sobre el barrio.

Los niños en este ejercicio desarrollaron sus habilidades comunicativas las cuales permitieron que pudieran compartir sus mundos y referirse a ellos, así:

Los sujetos capaces de lenguaje y de acción, pueden referirse a más de un mundo, y que al entenderse entre sí sobre algo en los dos mundos basan su comunicación en un sistema compartido de mundos [...] La acción comunicativa depende de contextos situacionales que a su vez son fragmentos del mundo de la vida de los participantes en la interacción. (Habermas, 2003, p. 358)

Objetivo 2: Fomentar las habilidades comunicativas desde el cuento Los cerdos de Anthony Browne para que los niños desarrollen el placer, el gozo por la lectura y el lenguaje crítico.

Para el desarrollo del objetivo 2 se aplicaron el taller No. 4 Escribiendo para comprender, taller No. 5 Improvisando ando y el taller No. 6 Conociendo el guión teatral con el propósito de incentivar la lectura y la escritura mediante el teatro y la literatura.

Taller No. 4

Escribiendo para comprender

\begin{tabular}{|l|l|l|l|}
\hline \multicolumn{1}{|c|}{ Objetivo } & \multicolumn{1}{|c|}{ Actividades } & Materiales & \multicolumn{1}{|c|}{ Tiempo } \\
\hline Objetivo & Etapa 1: Motivación (20 & $\bullet$ El cuento & 90 \\
general: & minutos) & $\bullet$ Marcadores & minutos \\
Fomentar las & Música y baile & $\bullet$ Hojas & \\
habilidades & La docente llevará ritmos & Lápices. & \\
comunicativas & brasileños de origen africano, & & \\
desde el cuento & como la samba, la batucada, la & & \\
Los cerdos de & capoeira que son excelentes para & & \\
\hline
\end{tabular}




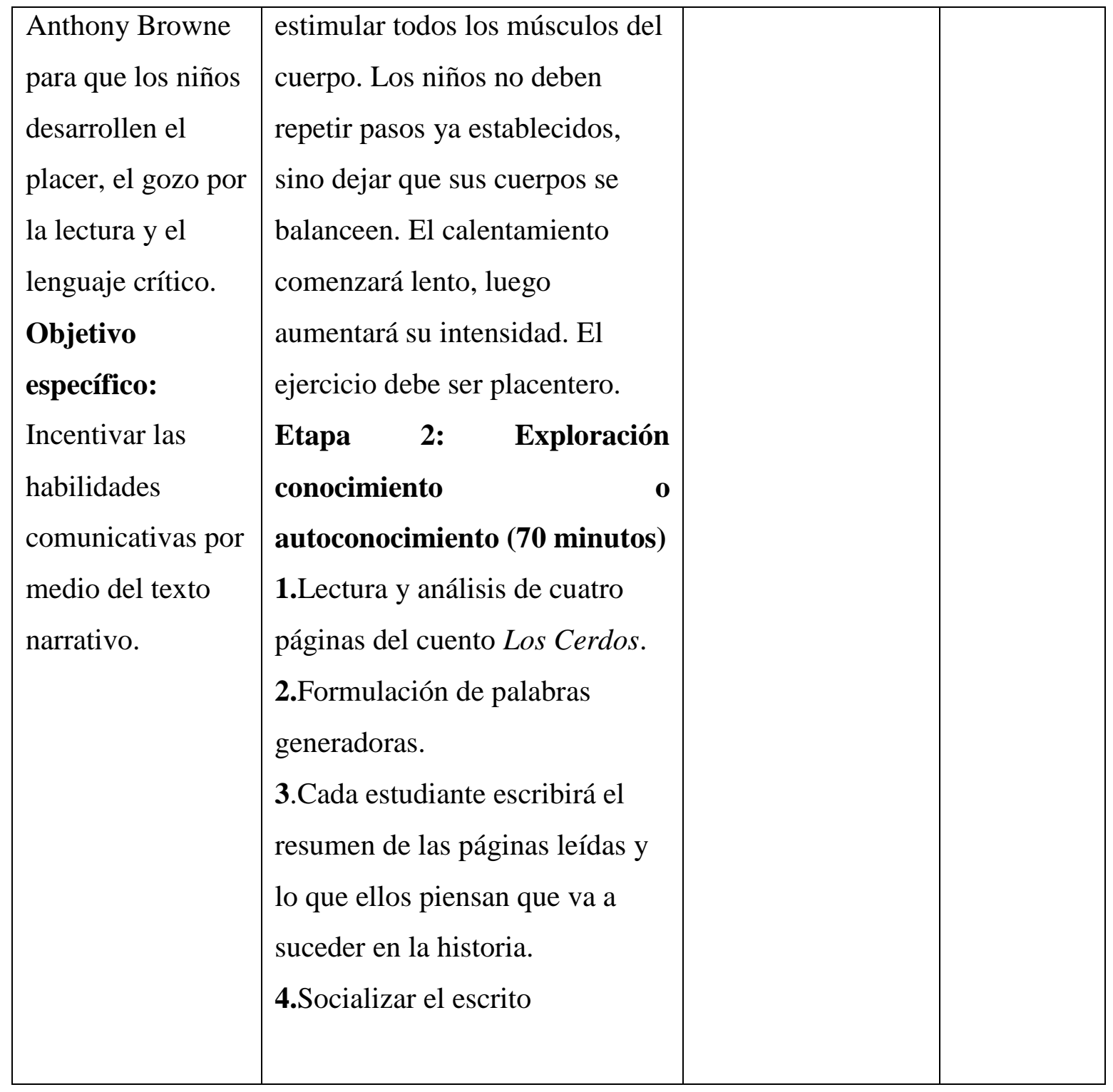

El día 17 de marzo asistieron veinte niños. El taller inició con un baile con ritmos diferentes como: salsa, mapalé, cumbia y samba. Los niños se organizaron por grupos y presentaron el baile. 


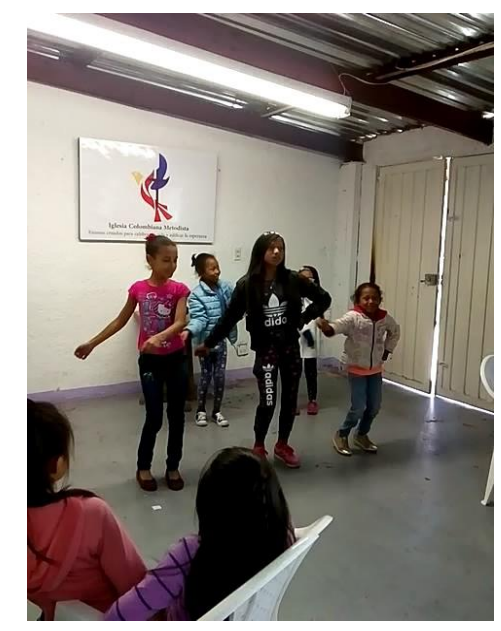

Objetivo 2. Taller No.4. Baile por grupos.

Luego, los niños leyeron colectivamente las primeras páginas del libro.

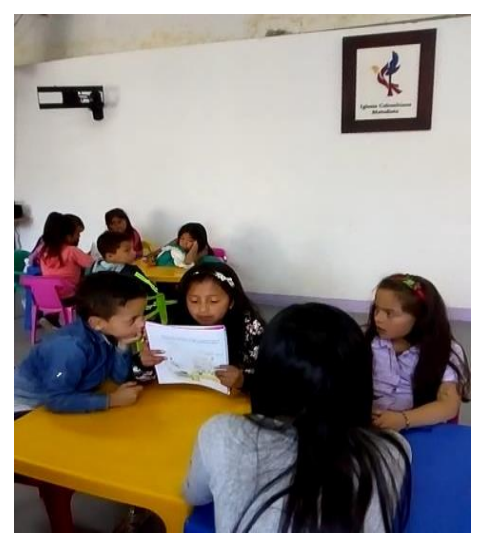

Objetivo 2. Taller No.4. Lectura colectiva.

Por último, escribieron el resumen de la lectura y formularon hipótesis sobre lo que sucederá en el cuento, además realizaron un dibujo

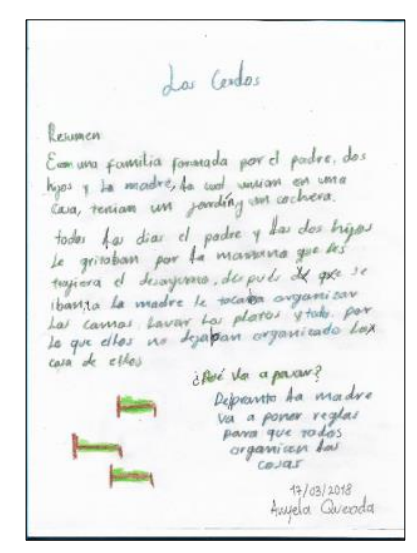


Objetivo 2. Escritura del resumen y formulación de hipótesis.

Las recurrencias fueron baile, exigencia, separación, cambio y colaboración. Se clasifican en dos categorías la primera expresión corporal: baile y la segunda comprensión de lectura: exigencia, separación, cansancio, enfermedad, cambio y colaboración.

La expresión corporal tiene dos etapas en la teoría y método de Boal, la primera conocer el cuerpo "tiene por finalidad deshacer las estructuras musculares de los participantes. Es decir, desmontarlas, verificarlas, analizarlas. No para que desaparezcan, pero sí para que se vuelvan conscientes" (Boal,1985, p.25). El baile lo que hace es que el cuerpo se vuelva expresivo quiere decir "que todos los participantes se esfuercen por expresar se a través de los cuerpos, cosa a la que no están acostumbrados" (Boal, 1985, p.28). Los niños demostraron que aman y disfrutan el baile, les encanta que sus cuerpos se tornen expresivos a través de la música ya que es una forma de comunicarse y compartir con los que están alrededor. Al finalizar la clase los niños hicieron la propuesta de un baile colectivo como se puede observar en la fotografía:

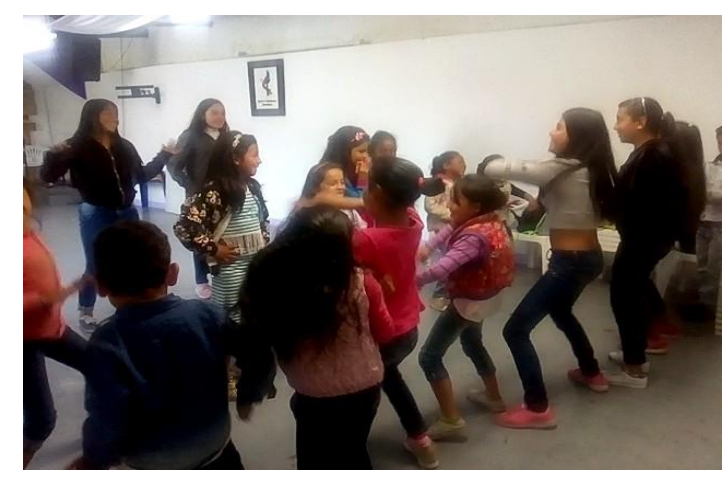

Objetivo 2. Taller No.4. Baile colectivo.

Los niños luego de leer y comprender la lectura llegaron a hipótesis cómo: "los papás y los hijos van a ayudar a la mamá", "la mamá se cansa de hacer oficio y se enferma"," la mamá pone reglas para que le ayuden" (Diario de campo No.5).

La niña D.P. plantea en su escrito que la mamá se va por un tiempo de la casa para brindarles una lección. En la formulación de la hipótesis ella va de la literatura hacia la realidad, hizo la lectura de la palabra y ahora la lectura del mundo, tomando una posición crítica a través de su escrito. Ve a la madre oprimida, por ello la libera con una actitud de valentía para cambiar el rumbo de la historia, y esa sería su posición en su mundo. La libertad radica en la construcción de un pensamiento diferente, eso significa ser crítico y reflexivo 
que permita "condiciones de descubrirse, conquistarse, reflexivamente, como sujeto de su propio destino histórico" (Freire, 2005, p. 11).

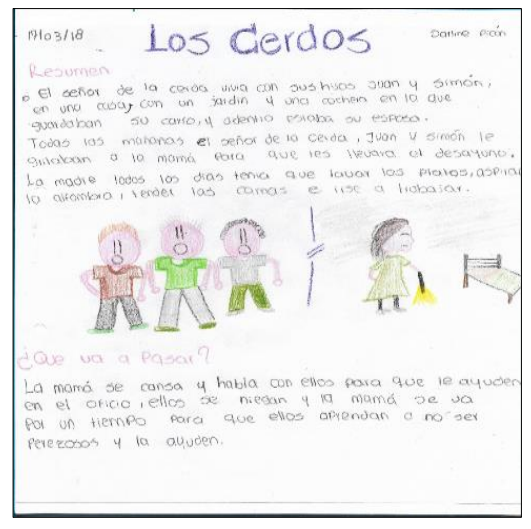

Objetivo 2. Taller No.4. Escritura del resumen y formulación de hipótesis.

\section{Taller No.5}

\section{Improvisando ando}

\begin{tabular}{|c|c|c|c|}
\hline Objetivo & Actividades & Materiales & Tiempo \\
\hline $\begin{array}{l}\text { Objetivo } \\
\text { general: } \\
\text { Fomentar las } \\
\text { habilidades } \\
\text { comunicativas } \\
\text { desde el cuento } \\
\text { Los cerdos de } \\
\text { Anthony Browne } \\
\text { para que los niños } \\
\text { desarrollen el } \\
\text { placer, el gozo por } \\
\text { la lectura y el } \\
\text { lenguaje crítico. }\end{array}$ & $\begin{array}{l}\text { Etapa 1: Motivación (20 } \\
\text { minutos) } \\
\text { Carretilla } \\
\text { Cada actor (estudiante) en el } \\
\text { suelo se apoya sobre las manos } \\
\text { y el otro lo sujeta por los pies. } \\
\text { Uno camina con las manos y el } \\
\text { otro sigue, como quien conduce } \\
\text { una carretilla. (Boal, 2012, } \\
\text { p.157) } \\
\text { Etapa 2: Exploración } \\
\text { conocimiento }\end{array}$ & $\begin{array}{ll}\text { - } & \text { El cuento } \\
\text { - } & \text { Marcadores } \\
\text { - } & \text { Hojas } \\
\text { - } & \text { Lápices. }\end{array}$ & $\begin{array}{l}90 \\
\text { minutos }\end{array}$ \\
\hline
\end{tabular}




\begin{tabular}{|l|l|l|}
\hline Objetivo & $\begin{array}{l}\text { autoconocimiento } \\
\text { específico: }\end{array}$ & minutos) \\
Incentivar las & $\begin{array}{l}\text { 1.Lectura y análisis de las } \\
\text { habilidades de }\end{array}$ & $\begin{array}{l}\text { siguientes seis páginas del El } \\
\text { lectura y escritura } \\
\text { en los educandos }\end{array}$ \\
a través del teatro. & $\begin{array}{l}\text { 2.Formulación de palabras } \\
\text { generadoras. } \\
\text { 3.Los estudiantes escribirán el } \\
\text { resumen de lo que se ha leído } \\
\text { 4.Por grupos improvisaran } \\
\text { sobre lo leído (El esposo y los } \\
\text { hijos llegando a la casa, } \\
\text { gritando por su almuerzo. Ella } \\
\text { les sirve y continúa con las } \\
\text { tareas del hogar. Mientras que } \\
\text { ellos descansan en la sala). }\end{array}$
\end{tabular} \mid

El día 24 de marzo asistieron doce niños. La primera actividad fue el juego Carretilla. Consiste que "Cada actor(estudiante) en el suelo se apoya sobre las manos y el otro lo sujeta por los pies. Uno camina con las manos y el otro sigue, como quien conduce una carretilla" (Boal, 2012, p.157). Como se mencionó anteriormente para trabajar los músculos del cuerpo y ser más conscientes de ellos. 


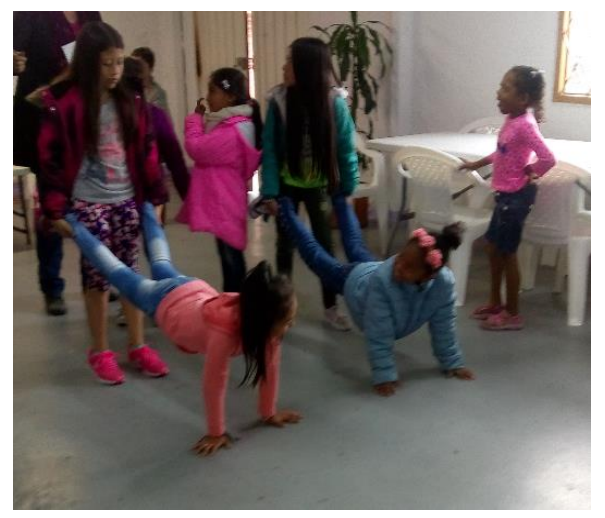

Objetivo 2. Taller No.5. Carretilla.

La segunda actividad fue la lectura de las imágenes y el texto del cuento Los cerdos

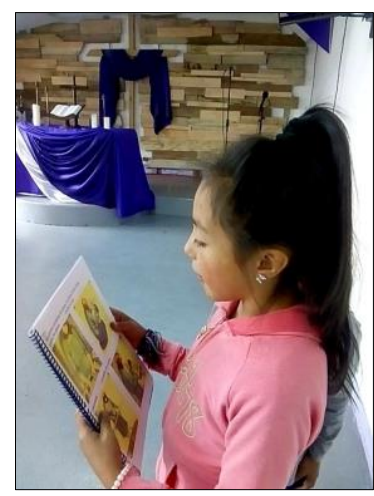

Objetivo 2. Taller No.5 Lectura de texto e imágenes.

La tercera actividad, los niños la escribieron el resumen de la lectura

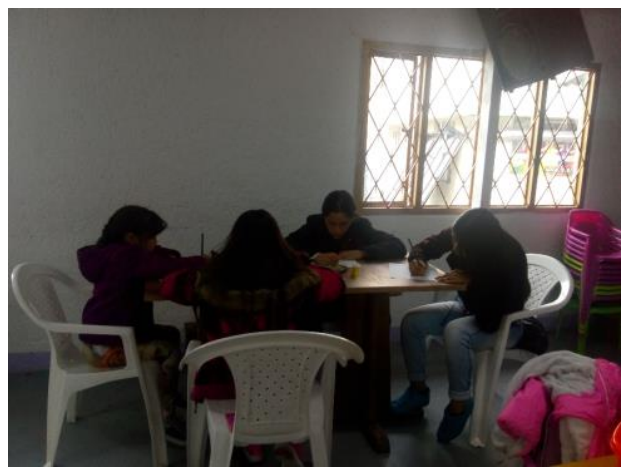

Objetivo 2. Taller No.5 Escritura del resumen.

En la última actividad, por grupos improvisaron lo que comprendieron de la lectura 


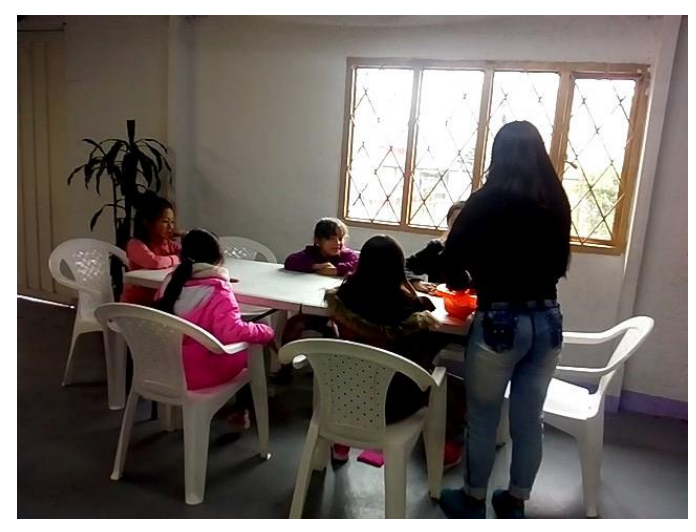

Objetivo 2. Taller No.5 Improvisación.

Las recurrencias del taller son creatividad, imaginación, oprimido-opresor, liberación, gozo, placer, lectura y escritura. Se clasifican en dos categorías, la primera habilidades comunicativas: lectura, escritura, gozo y placer; la segunda improvisación: oprimido-opresor, liberación, creatividad e imaginación.

La lectura del libro-álbum Los cerdos despierta el placer y el gozo por la literatura ya que se da una lectura no convencional. Dado que, "el álbum además de ser un libro, y por encima del libro que es, es algo más, es la plasmación de una forma de comunicación, basada en una forma de representación, que provoca un nuevo "modo de leer" (Banco del libroGRETEL, 2010, p. 187). Los niños leían las imágenes, realizaban la descripción y seguían la secuencia del cuento mostrando su interés por la lectura. Así como la niña A.T. lee la imagen que se presenta en la página para comprender el mensaje de la lectura

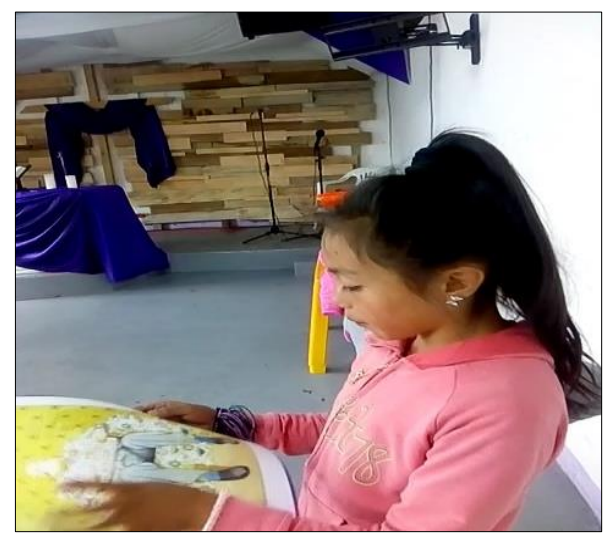

Objetivo 2. Taller No.5 Lectura de imágenes y texto. 
El libro-álbum permite las dos lecturas del texto y la imagen. Las dos están apoyadas para la comprensión del mensaje. Así,

el diálogo entre lo dicho por el texto escrito y lo dicho por la ilustración es fundamental para la construcción conjunta de sentidos. Pero también es imprescindible cómo ambos códigos, el lingüístico y el de la imagen, construyen a dúo lo que no se dice. (Banco del libro- GRETEL, 2010, p. 117)

Por otro lado, por medio de la escritura del resumen se evidencio que el mensaje fue claro para los niños, la mamá oprimida por los opresores de su esposo e hijos. Y la liberación que la mujer quiere obtener. Entonces, leer y escribir son herramientas que permiten a los niños tener una adecuada compresión e interpretación del mundo, por esa razón

el aprendizaje de la lectura y de la escritura, por eso mismo, no tendrá significado real si se hace a través de la repetición puramente mecánica de silabas. Ese aprendizaje es válido cuando, simultáneamente con el dominio de la formación de vocablos, el educando va percibiendo el sentido profundo del lenguaje: cuando va percibiendo la solidaridad que existe entre el lenguaje- pensamiento y la realidad, cuya transformación, al exigir nuevas formas de comprensión, plantea también la necesidad de nuevas formas de expresión. (Freire, 1998, p.55)

La niña D.P. escribe no sólo el resumen sino lo que piensa sobre lo leído. La mujer oprimida que se libera abandonando su hogar y dejando una nota a sus opresores.

Deduciendo la preocupación que sienten ellos.

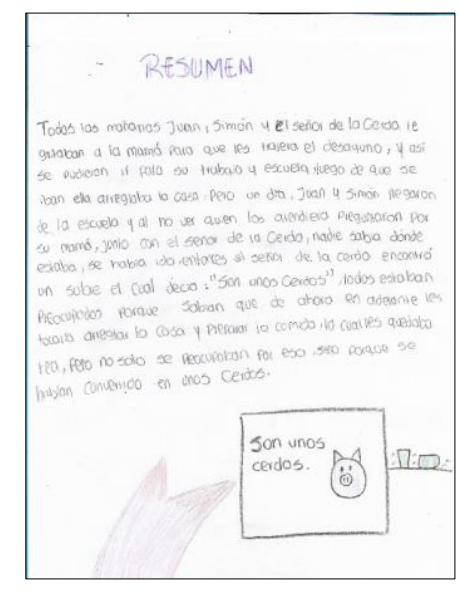

Objetivo 2. Taller No. 5 Escritura del resumen 
Por otra parte, en la improvisación el niño S.R. manifestó la posible solución al problema que se planteaba en la lectura. Él creó un monólogo donde interpretaba el papel del esposo y le dice a sus hijos "Niños ¿qué es este todo reguerote? Cuando su mamá llegue tendrá que limpiar todo esto y estará muy cansada" (marzo 24 de 2018, Taller No.5) y se convierte en cerdo. En escena él demuestra su pensamiento y reflexión crítica que le genero el mensaje de la lectura porque es una situación de la realidad. En su personaje intenta solucionar la problemática, pero asume las consecuencias de sus malos actos.

El niño S.R. llega al objetivo del Teatro del Oprimido que no es comprender o interpretar un rol determinado, sino que los sujetos entiendan su vida y asímismo puedan encontrar sus propias soluciones a los problemas del día a día, haciendo una construcción simbólica de ellas en escena y luego la transporten a su vida cotidiana. "El teatro del oprimido crea espacios de libertad donde la gente pueda dar rienda suelta a sus recuerdos, emociones, imaginación, pensar en el pasado, en el presente e inventar su futuro en lugar de sentarse a esperarlo de brazos cruzados" (Boal, 2002 p.14).

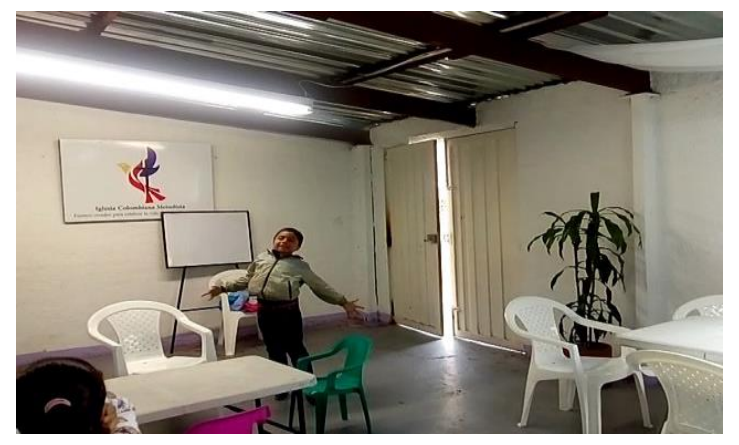

Objetivo 2. Taller No.5 Improvisación.

La creatividad y la imaginación se vieron reflejadas en las improvisaciones, el niño nombrado anteriormente utilizo su expresión corporal para la transformación de ser humano a animal. La niña A.Q. utiliza su imaginación para desempeñar la acción de barrer

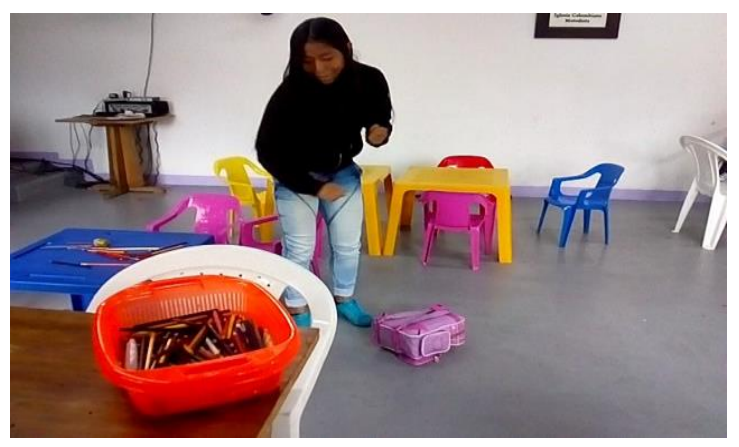

Objetivo 2. Taller No.5 Improvisación. 
También utiliza su creatividad utilizando una caja como si fuera la lavaplatos y los lápices como si fueran los platos y cubiertos

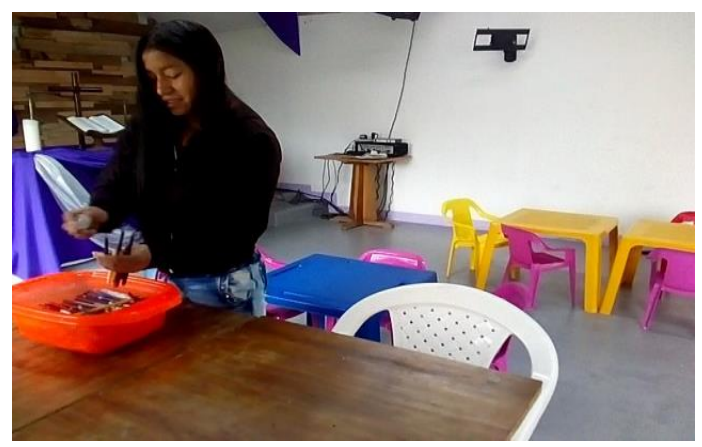

Objetivo 2. Taller No.5 Improvisación.

La niña realiza con estas acciones es lo que dice Boal

el actor no solo debe entender y sentir como su personaje, debe asimismo presentarlo al público de un modo artístico, como un artista. [...] para el actor el imprescindible mostrar. Así pues, es preciso que sienta todos los pasos, en su interior para ser capaz de mostrarlos al exterior, al público. (2012, p.12)

Muestra a su personaje en todas sus dimensiones por medio de la creatividad y la imaginación.

Taller No.6

Conociendo el guión teatral

\begin{tabular}{|c|c|c|c|}
\hline Objetivo & Actividades & Materiales & Tiempo \\
\hline $\begin{array}{l}\text { Objetivo } \\
\text { general: } \\
\text { Fomentar las } \\
\text { habilidades } \\
\text { comunicativas } \\
\text { desde el cuento } \\
\text { Los cerdos de } \\
\text { Anthony Browne } \\
\text { para que los niños } \\
\text { desarrollen el } \\
\text { placer, el gozo por }\end{array}$ & $\begin{array}{l}\text { Etapa 1: Motivación (10 } \\
\text { minutos) } \\
\text { Estatua de sal } \\
\text { Un perseguidor y todos los } \\
\text { perseguidos: quien sea tocado } \\
\text { por el perseguidor se convierte } \\
\text { en estatua de sal, se inmoviliza } \\
\text { en su posición, siempre con las } \\
\text { piernas abiertas: solo puede ser } \\
\text { liberado si alguien, aun libre, } \\
\text { pasa por debajo de sus piernas. }\end{array}$ & $\begin{array}{ll}\text { - } & \text { El cuento } \\
\text { - } & \text { Marcadores } \\
\text { - } & \text { Hojas } \\
\text { - } & \text { Lápices } \\
\text { - } & \text { Bitácora }\end{array}$ & $\begin{array}{l}90 \\
\text { minutos }\end{array}$ \\
\hline
\end{tabular}




\begin{tabular}{|c|c|}
\hline $\begin{array}{l}\text { la lectura y el } \\
\text { lenguaje crítico. } \\
\text { Objetivo } \\
\text { específico: } \\
\text { Incentivar las } \\
\text { habilidades de } \\
\text { lectura y escritura } \\
\text { en los educandos } \\
\text { a través de la } \\
\text { literatura y el } \\
\text { teatro. }\end{array}$ & $\begin{array}{l}\text { Si solo es un perseguidor fuese } \\
\text { poco, después de un tiempo de } \\
\text { juego, en un segundo comienzo } \\
\text { se designan dos, tres o más, } \\
\text { hasta que sea posible } \\
\text { inmovilizar el grupo entero. } \\
\text { (Boal, 2012, p. 168) } \\
\text { Etapa } \\
\text { conocimiento } \\
\text { autoconocimiento } \\
\text { minutos) } \\
\text { 1.Explicación del guión teatral } \\
\text { con la primera escena del Libro } \\
\text { de los Cerdos. } \\
\text { 2.Representación de la escena } \\
\text { 3.Lectura y análisis de las } \\
\text { siguientes diez páginas del } \\
\text { cuento (El abandono de la } \\
\text { esposa a su familia por el } \\
\text { maltrato) } \\
\text { 4.Creación del personaje que } \\
\text { les gustaría interpretar en la } \\
\text { obra (Escritura) }\end{array}$ \\
\hline
\end{tabular}

El día 7 de abril asistieron catorce niños. El taller comenzó con el ejercicio Estatua de sal que consistía

Un perseguidor y todos los perseguidos: quien sea tocado por el perseguidor se convierte en estatua de sal, se inmoviliza en su posición, siempre con las piernas abiertas: solo puede ser liberado si alguien, aun libre, pasa por debajo de sus piernas. Si solo es un perseguidor fuese poco, después de un tiempo de juego, en 
un segundo comienzo se designan dos, tres o más, hasta que sea posible inmovilizar el grupo entero. (Boal, 2012, p. 168)

Después, la docente explico el guión teatral con la primera escena del libro y el concepto de adaptación. A continuación, por grupos realizaron la lectura dramática de la escena.

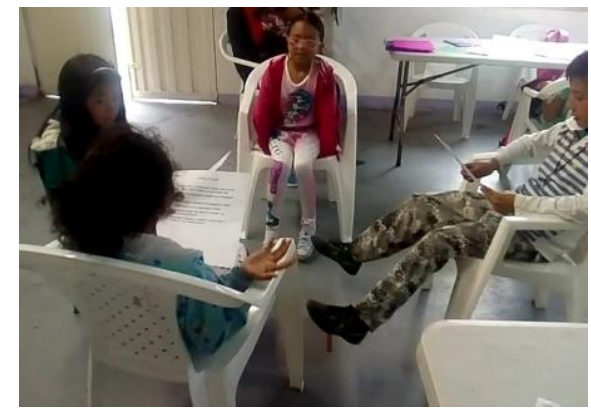

Objetivo 2. Taller No.6. Lectura dramática.

Luego, los niños leyeron en voz alta las penúltimas páginas del cuento.

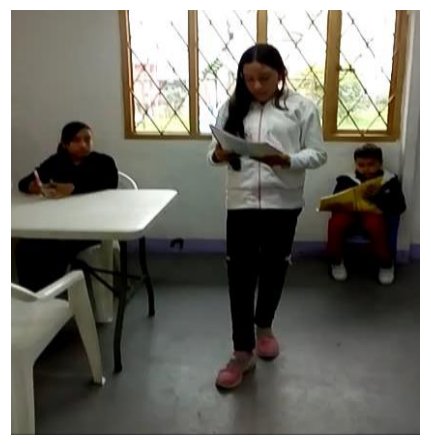

Objetivo 2. Taller No. 6 Lectura en voz alta

Al finalizar el taller cada estudiante escribió y dibujo sobre el personaje que deseaba interpretar en la obra de teatro, podía seleccionar uno del cuento o crearlo.

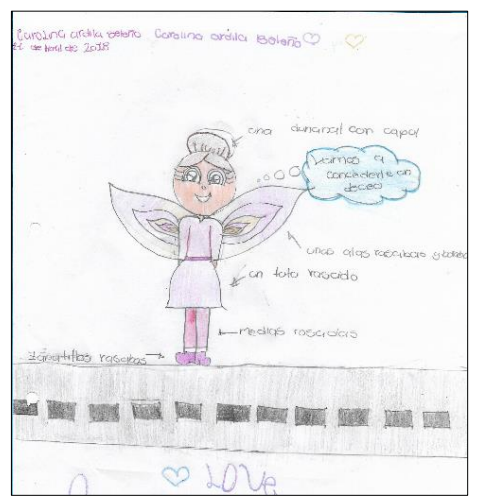




\section{Objetivo 2. Taller No. 6 Creación del personaje}

Las recurrencias del taller fueron hadas, profesoras, tía, directora de colegio las respuestas salieron del último ejercicio. La categoría es creación de personajes.

A partir de la lectura de las penúltimas páginas del libro, los niños tuvieron la necesidad de crear nuevos personajes para complementar la historia. Demostrando que la lectura es significativa para ellos y el mensaje que está transmitiendo el cuento lo está comprendiendo, por consiguiente, desean e inventan nuevos seres para que participen en la obra de teatro, aportando a la adaptación teatral del cuento Los cerdos. La niña A.F. propone ser la profesora, además escribe el guión de la escena donde ella participará. Mostrando que la lectura del texto narrativo la motiva a construir un personaje y un guión:

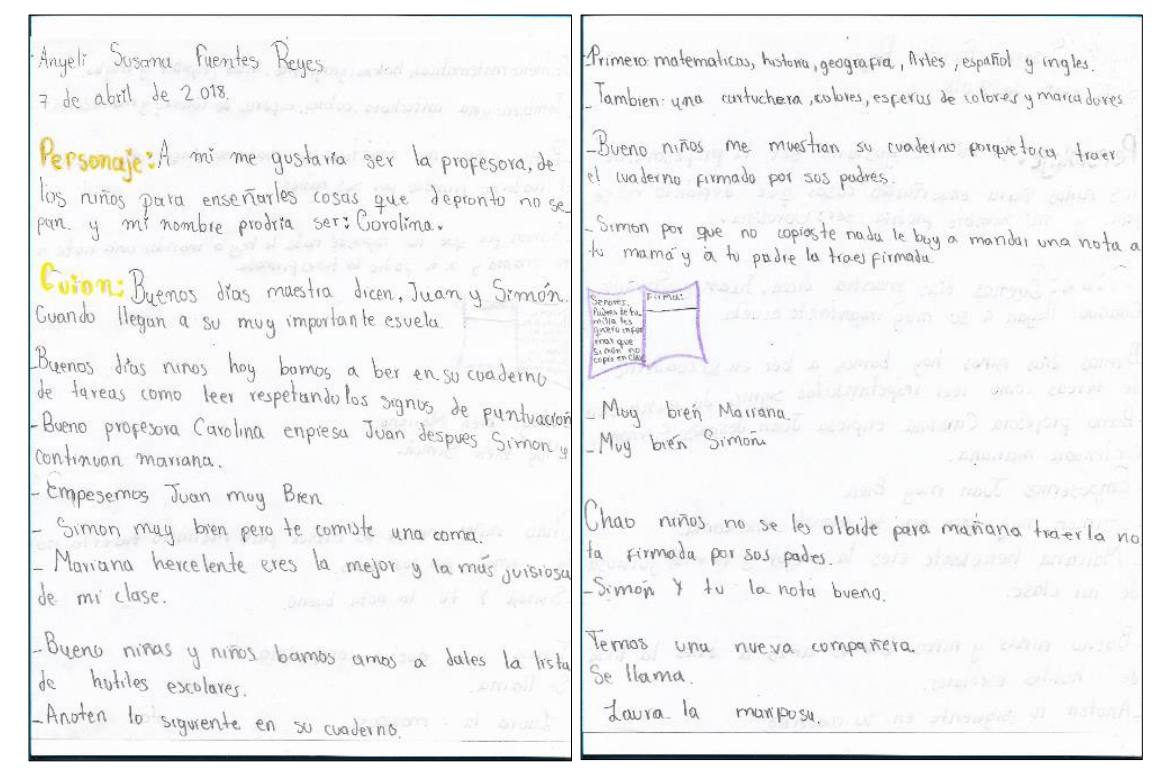

Objetivo 2. Taller No.6 Creación de personajes.

La palabra posibilita la creación de un mundo ideal. Por lo tanto, no es válido decir que aprender a leer y a escribir son procesos mecánicos y rígidos sin sentido, teniendo en cuenta que

La alfabetización no es un juego de palabras, sino la conciencia reflexiva de la cultura, la reconstrucción, crítica del mundo humano, la apertura de nuevos caminos, el proyecto histórico de un mundo común, el coraje de decir su palabra. [...] Aprender a 
leer es aprender a decir su palabra. Y la palabra humana imita a la palabra divina: es creadora. [...] La palabra se entiende aquí como palabra y acción. Palabra viva y dinámica y no categoría inerte y no exánime. Palabra que dice y transforma el mundo. (Freire, 2005, p. 27)

La niña A.F. demuestra que la lectura y la escritura superan lo mecánico de los procesos, van más allá. Le permiten hacer parte de la historia y darle un nuevo rumbo. También por las experiencias que ha tenido desde su realidad, ya que "la construcción social de tales experiencias les ofrece la oportunidad de dar significado y expresión a sus propias necesidades y voces, como parte de un proyecto de adquisición por sí y socialmente de facultades críticas" (Giroux, 1998, p.233)

Objetivo 3. Aplicar una estrategia pedagógica de liberación de Los cerdos de Anthony Browne, a través de talleres de lectura y escritura, fundamentados en la teoría y estética teatral del oprimido.

Para el desarrollo del objetivo 3 se aplicaron tres talleres que fueron el taller No. 7 Expresando nuestras opiniones, taller No.8 Produciendo nuestro guión teatral, taller No. 9 ¡Listos, cámara, acción! I y taller No.10 ¡Listos, cámara, acción! II con el objetivo de fomentar la liberación a través del método de Boal y la literatura desde el libro-álbum Los Cerdos de Anthony Browne.

\section{Taller No.7}

\section{Expresando nuestras opiniones}

\begin{tabular}{|c|c|c|c|}
\hline Objetivo & Actividades & Materiales & Tiempo \\
\hline $\begin{array}{l}\text { Objetivo general: } \\
\text { Aplicar una } \\
\text { estrategia } \\
\text { pedagógica de } \\
\text { liberación de Los } \\
\text { cerdos de } \\
\text { Anthony Browne, } \\
\text { a través de talleres }\end{array}$ & $\begin{array}{l}\text { Etapa 1: Motivación (15 } \\
\text { minutos) } \\
\text { Bosque de sonidos } \\
\text { El grupo se divide en parejas: } \\
\text { un miembro será el ciego; otro, } \\
\text { el lazarillo. Este último emite } \\
\text { sonidos de un animal -gato, } \\
\text { perro, pájaro o cualquier otro-, }\end{array}$ & $\begin{array}{ll}\text { - } & \text { El cuento } \\
\text { - } & \text { Marcadores } \\
\text { - Hojas } \\
\text { - Lápices. }\end{array}$ & $\begin{array}{l}90 \\
\text { minutos }\end{array}$ \\
\hline
\end{tabular}




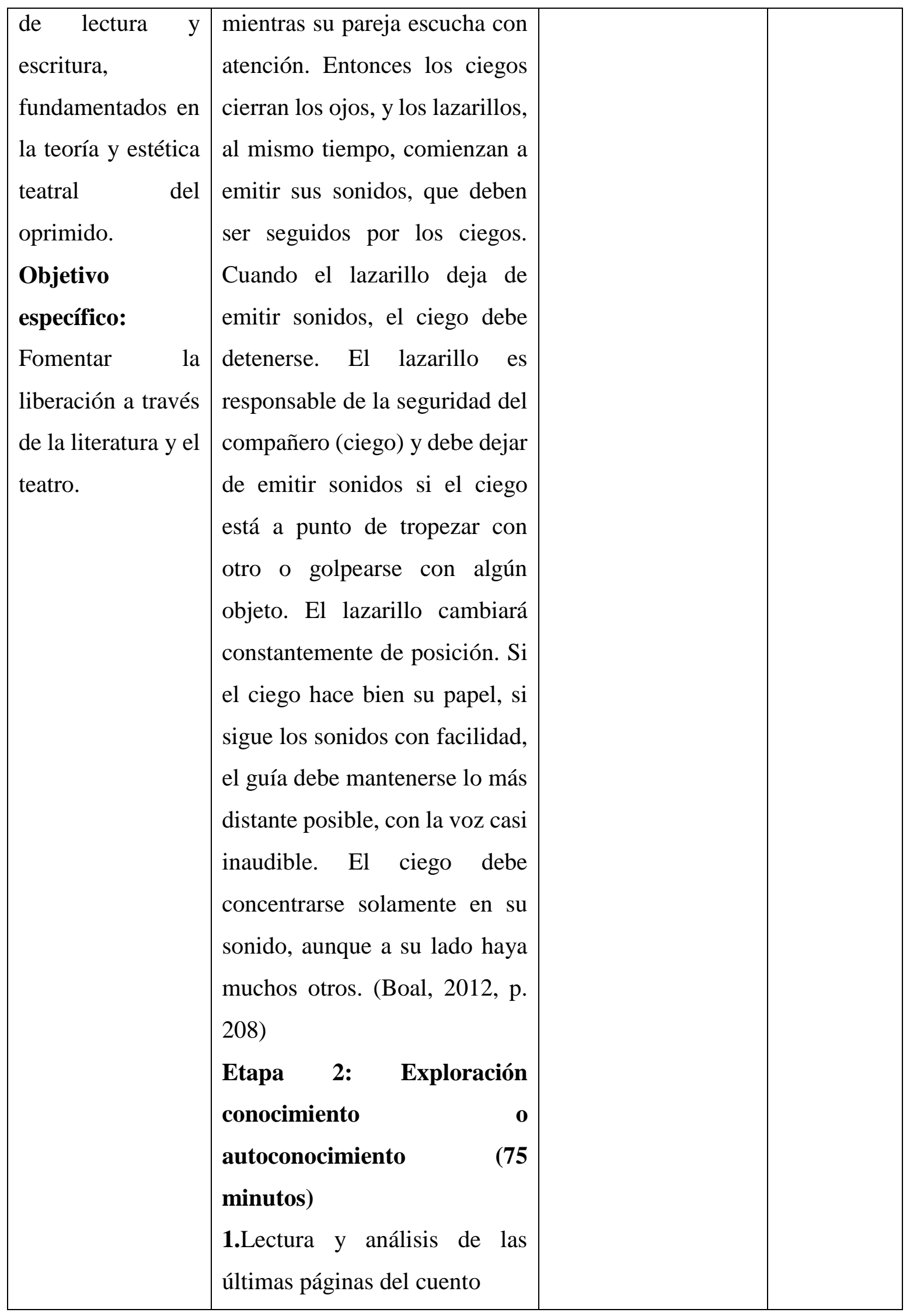




\begin{tabular}{|c|c|c|}
\hline & & $\begin{array}{l}\text { 2.Escritura sobre la opinión del } \\
\text { cuento (¿qué le gusto o no?) } \\
\text { 3.Escritura sobre la adaptación } \\
\text { del cuento } \\
\text { 4.Socialización }\end{array}$ \\
\hline
\end{tabular}

El día 14 de abril asistieron quince niños. El taller comenzó con un ejercicio para activar los sentidos como es el bosque de sonido, consistió:

El grupo se divide en parejas: un miembro será el ciego; otro, el lazarillo. Este último emite sonidos de un animal -gato, perro, pájaro o cualquier otro-, mientras su pareja escucha con atención. Entonces los ciegos cierran los ojos, y los lazarillos, al mismo tiempo, comienzan a emitir sus sonidos, que deben ser seguidos por los ciegos. Cuando el lazarillo deja de emitir sonidos, el ciego debe detenerse. El lazarillo es responsable de la seguridad del compañero (ciego) y debe dejar de emitir sonidos si el ciego está a punto de tropezar con otro o golpearse con algún objeto. El lazarillo cambiará constantemente de posición. Si el ciego hace bien su papel, si sigue los sonidos con facilidad, el guía debe mantenerse lo más distante posible, con la voz casi inaudible. El ciego debe concentrarse solamente en su sonido, aunque a su lado haya muchos otros. (Boal, 2012, p. 208)

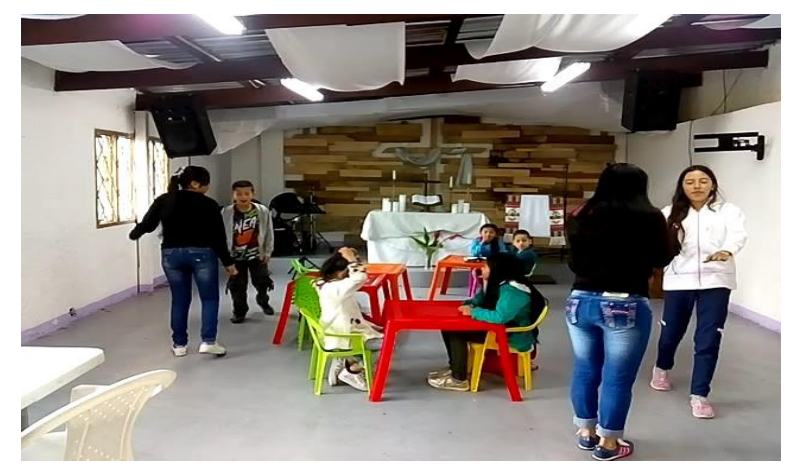

Objetivo 3. Taller No.7Bosque de sonidos.

En seguida, se realizó la lectura en voz alta de las últimas páginas del cuento. 


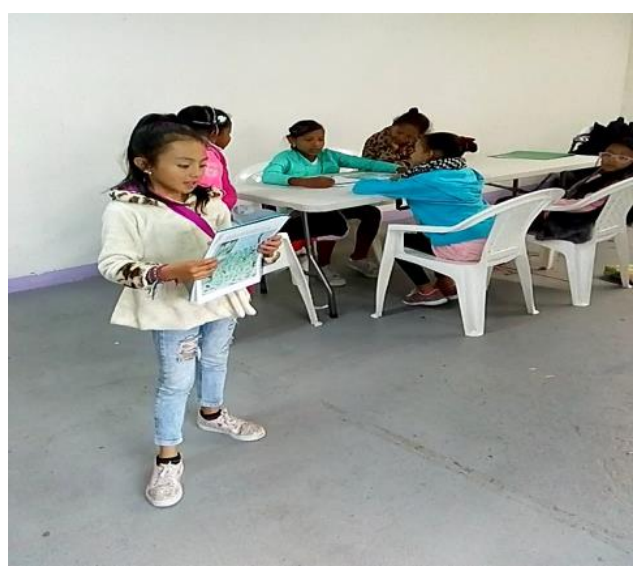

Objetivo 3. Taller No.7 Lectura en voz alta

La última actividad fue la escritura sobre lo que les gusto o no del cuento y qué le agregarían a la historia.

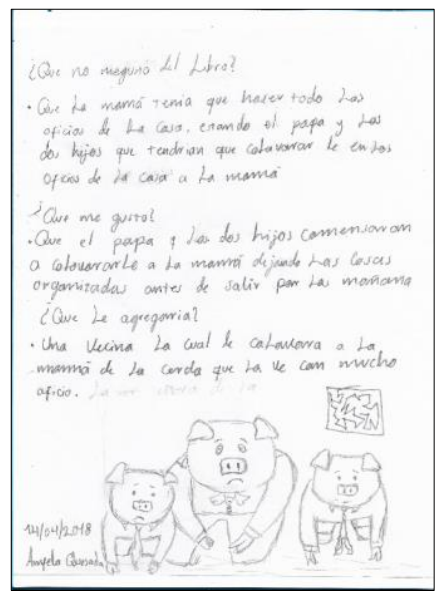

Objetivo 3. Taller No.7 Escritura sobre las opiniones respecto al cuento.

Las recurrencias del taller fueron maltrato, lección, colaboración, tía, profesoras, hadas, ángel, sol y flor. Lo que no les gusto del cuento fue el maltrato hacía la mujer, lo que les gusto la lección aprendida y la colaboración que le brindaron al final el esposo y los hijos. Los niños quisieron mantener la historia, pero agregarle personajes que ayudarían a los demás. Las categorías en que se clasificarían son: la primera, pensamiento crítico: maltrato, lección, colaboración y la segunda teatro: personajes: tía, profesoras, vecina, hadas, ángel, sol y flor.

Los niños comprendieron adecuadamente el mensaje de la lectura, ya que pudieron tomar postura frente a la situación que se planteaba y expresar sus opiniones basándose en su realidad. Así, 
Toda lectura es interpretación y lo que el lector es capaz de comprender y de aprender a través de la lectura depende fuertemente de lo que el lector conoce y cree antes de la lectura. Diferentes personas leyendo el mismo texto variaran en lo que comprendan de él, según sean sus contribuciones personales al significado. Pueden interpretar solamente sobre la base de lo que conocen. (Ferreiro, 1982, p.18)

La niña D.P. escribe que no le gusto que el padre y los hijos no le colaboraran a la mujer en las actividades del hogar. Y está de acuerdo que la señora se fuera de la casa para liberarse y de esta forma ellos reflexionarán sobre sus malos actos.

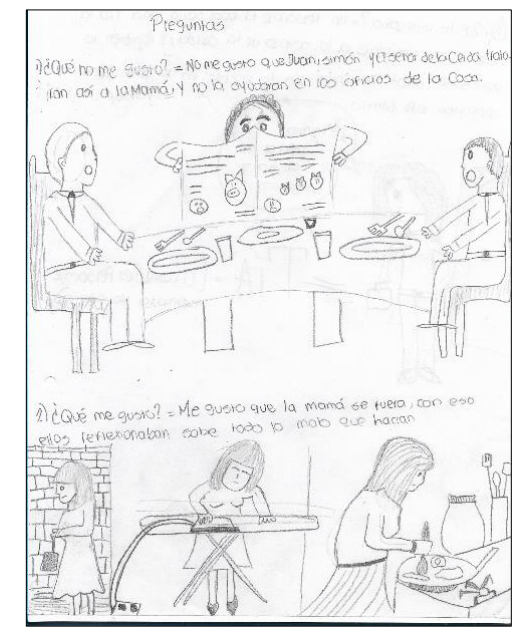

Objetivo 3. Taller No.7 Escritura sobre las opiniones del cuento.

La niña comprendió el significado del texto, por lo tanto, expresa su postura frente a la historia. Ya que

La búsqueda de significado es la característica más importante del proceso de lectura y es en el ciclo semántico que todo toma su valor. El significado es construido mientras leemos, pero también es reconstruido ya que debemos reacomodar continuamente nueva información y adaptar nuestro sentido de significado en formación. A lo largo de la lectura de un texto, e incluso, luego, el lector está continuamente reevaluando el significado y reconstruyéndolo en la medida que se obtiene nuevas percepciones. La lectura es, pues, un proceso dinámico muy activo. Los lectores utilizan todos sus esquemas conceptuales cuando tratan de comprender. (Ferreiro, 1982, p.24)

La niña D.P. desarrolla un pensamiento crítico porque crea un personaje nuevo que es la hermana de la mujer con el objetivo de brindarle apoyo y seguridad en la decisión que 
eligió, además quiere que se amplíe el final que es el momento feliz de la familia, donde se evidencia el cambio de la relación opresor-oprimido.

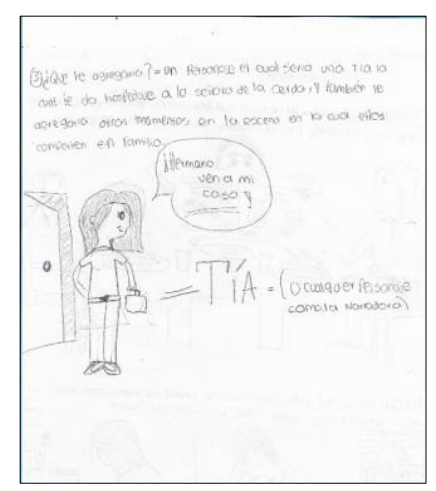

Objetivo 3. Taller No. 7 Propuesta de adaptación.

La niña plantea la propuesta desde su mundo. Entonces, la lectura y la escritura son habilidades que ayudan a los sujetos a conocer su realidad, hacer parte de ella y transformarla. Para Freire "la alfabetización era ante todo abrir espacios de lucha, en donde los oprimidos se transformasen en sujetos en un proceso de conocimiento transformador de su realidad" (2004, p.11)

\section{Taller No.8}

\section{Produciendo nuestro guión teatral}

\begin{tabular}{|c|c|c|c|}
\hline Objetivo & Actividades & Materiales & Tiempo \\
\hline $\begin{array}{l}\text { Objetivo general: } \\
\text { Aplicar una } \\
\text { estrategia } \\
\text { pedagógica de } \\
\text { liberación de } \text { Los } \\
\text { cerdos de } \\
\text { Anthony Browne, } \\
\text { a través de talleres } \\
\text { de lectura y } \\
\text { escritura, }\end{array}$ & $\begin{array}{l}\text { Etapa 1: Motivación (10 } \\
\text { minutos) } \\
\text { El coche ciego } \\
\text { Una persona detrás de otra. La } \\
\text { que va adelante es el coche } \\
\text { ciego. Por detrás, el conductor } \\
\text { guiará los movimientos del } \\
\text { coche ciego, presionando con } \\
\text { los dedos en medio de la } \\
\text { espalda (el coche avanza en }\end{array}$ & $\begin{array}{ll}\text { - } & \text { El cuento } \\
\text { - } & \text { Marcadores } \\
\text { - } & \text { Hojas } \\
\text { - } & \text { Lápices }\end{array}$ & $\begin{array}{l}90 \\
\text { minutos }\end{array}$ \\
\hline
\end{tabular}




\begin{tabular}{|c|c|}
\hline $\begin{array}{l}\text { fundamentados en } \\
\text { la teoría y estética } \\
\text { teatral del } \\
\text { oprimido. } \\
\text { Objetivo } \\
\text { específico: } \\
\text { Fomentar } \\
\text { liberación a través } \\
\text { de la creación de } \\
\text { una nueva versión } \\
\text { del cuento Los } \\
\text { Cerdos donde se } \\
\text { evidencie } \\
\text { construcciones } \\
\text { simbólicas de las } \\
\text { soluciones a la } \\
\text { problemática } \\
\text { trabajada en el } \\
\text { libro. }\end{array}$ & 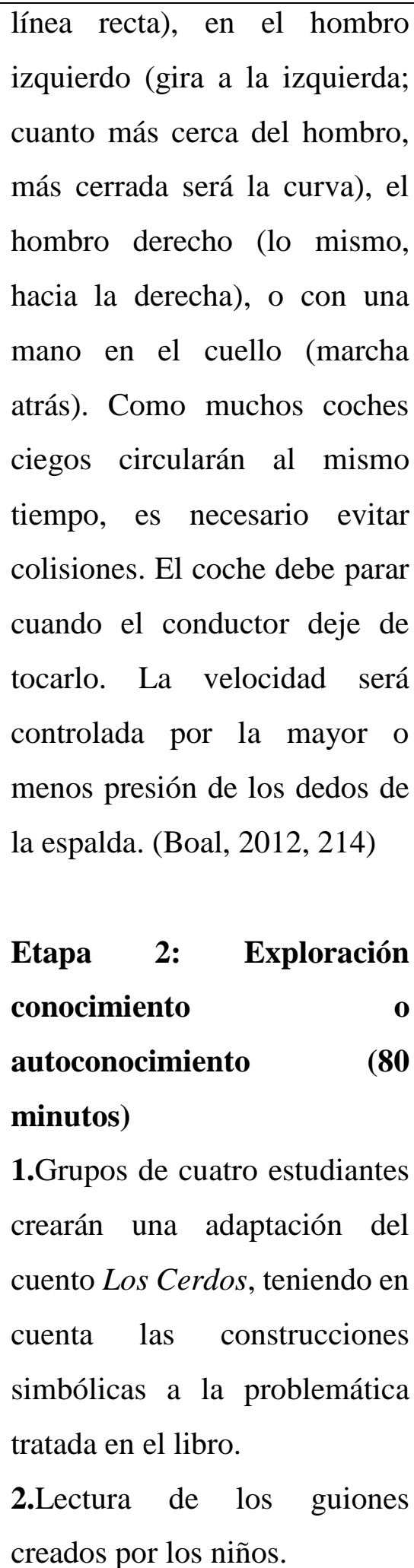 \\
\hline
\end{tabular}




\begin{tabular}{|c|c|}
\hline & $\begin{array}{l}\text { 3.Selección de personajes e } \\
\text { ideas para la construcción de la } \\
\text { versión final del guión teatral. }\end{array}$ \\
\hline
\end{tabular}

El día 21 de abril asistieron veintiuno niños. El taller comienza con el ejercicio del coche ciego con el fin de activar los sentidos. El juego consiste

Una persona detrás de otra. La que va adelante es el coche ciego. Por detrás, el conductor guiará los movimientos del coche ciego, presionando con los dedos en medio de la espalda (el coche avanza en línea recta), en el hombro izquierdo (gira a la izquierda; cuanto más cerca del hombro, más cerrada será la curva), el hombro derecho (lo mismo, hacia la derecha), o con una mano en el cuello (marcha atrás). Como muchos coches ciegos circularán al mismo tiempo, es necesario evitar colisiones. El coche debe parar cuando el conductor deje de tocarlo. La velocidad será controlada por la mayor o menos presión de los dedos de la espalda. (Boal, 2012, 214)

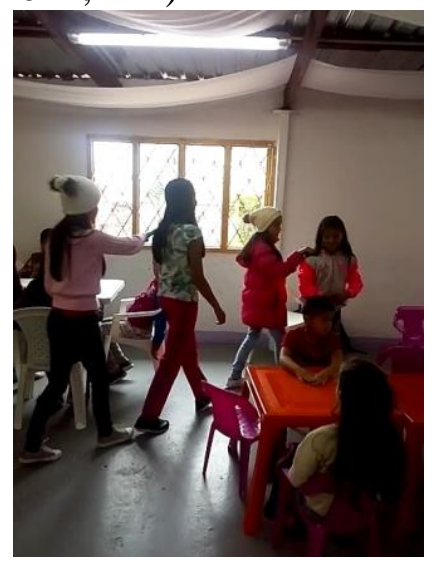

Objetivo 3. Taller No.8 El coche ciego

Luego, se asignó los personajes y se realizó la lectura colectiva de la versión final del guión teatral. 


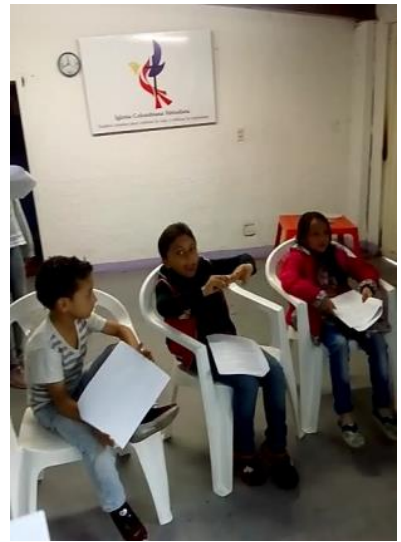

Objetivo 3. Taller No.8 Lectura de la primera versión del guión teatral

Finalmente, los niños escribieron lo que deseaban complementar al guión y lo socializaron.

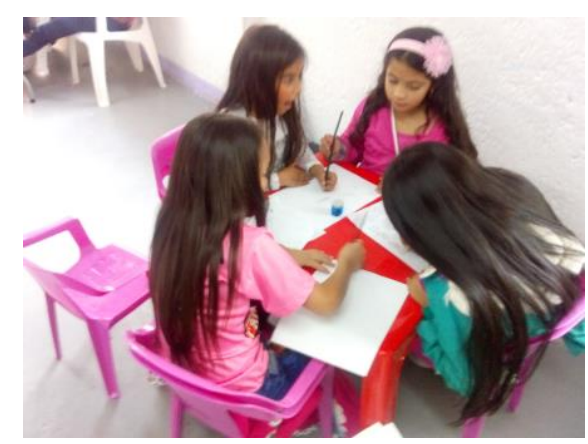

Objetivo 3. Taller No. 8 Escritura de ideas para complementar la primera versión del guión.

Las recurrencias fueron lección y ayuda. La categoría es pensamiento crítico. En el ejercicio de proponer nuevas ideas para complementar el guión teatral los niños plantearon su postura, por ejemplo, la niña V.M. complemento su diálogo desde su personaje que es una profesora mostrando más apoyo a la familia para solucionar la problemática

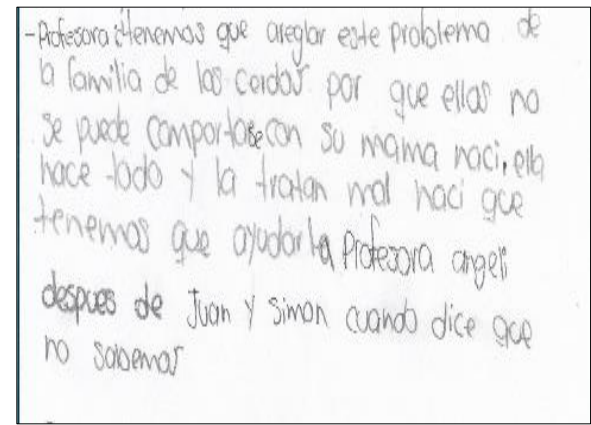

Objetivo 3. Taller No.8 Escritura de ideas para complementar la primera versión del guión. 
Se debe formar a los niños en la pedagogía crítica para que obtenga una alfabetización crítica que consiste en

un proceso de construir lenguaje, y utilizarlo críticamente (oralmente o por escrito) como medio de expresión, de interpretación y de transformación de nuestras vidas y de las vidas de aquellos que nos rodean. (McLaren, 2008, p.279)

La niña A.T. propone desde su personaje que es la mamá darle una lección a su esposo e hijos, dejando la casa por unos días. Ella manifiesta su pensamiento mostrando que las personas deben aprender de sus errores.

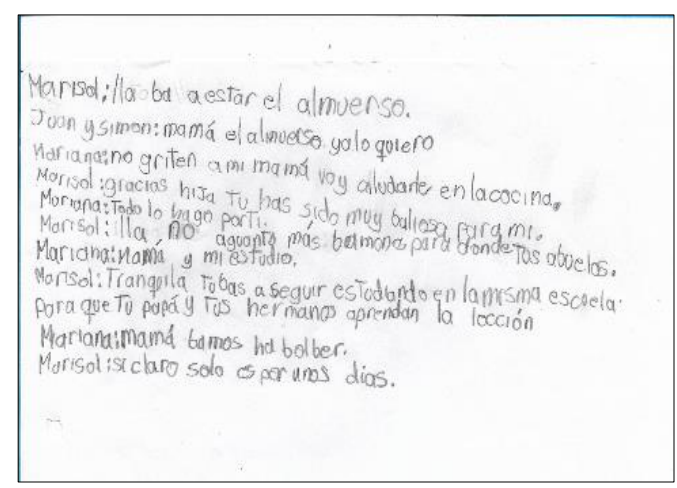

Objetivo 3. Taller No.8 Escritura de ideas para complementar la primera versión del guión.

Es una situación que se presenta en la realidad y la niña expresa qué haría en esa problemática. Entonces, en la educación se debe implementar una pedagogía crítica para fortalecer el pensamiento de los niños ya que

La pedagogía critica no se preocupa solamente de ofrecer a los alumnos y alumnas nuevas formas de pensar de manera crítica y de actuar con autoridad en las aulas, conscientes de su papel de agentes de cambio; también se preocupa de proporcionar a los alumnos y alumnas las habilidades y los conocimientos necesarios para que amplíen las capacidades, ya sea para cuestionar las suposiciones y los mitos fuertemente asentados que legitiman los hábitos sociales más arcaicos y restrictivos (que estructuran todos los aspectos de la sociedad) o para asumir su responsabilidad de intervenir en el mundo que habitan. (McLaren, 2008, p. 18)

\section{Taller No. 9}

¡Listos, cámara, acción! I

\begin{tabular}{|c|l|c|c|}
\hline \multicolumn{1}{|c|}{ Objetivo } & \multicolumn{1}{|c|}{ Actividades } & Materiales & Tiempo \\
\hline $\begin{array}{l}\text { Objetivo general: } \\
\text { Aplicar 1: Motivación (15 }\end{array}$ & $\begin{array}{l}\text { Etapa El guión } \\
\text { minutos) }\end{array}$ & 90 \\
minutos
\end{tabular}




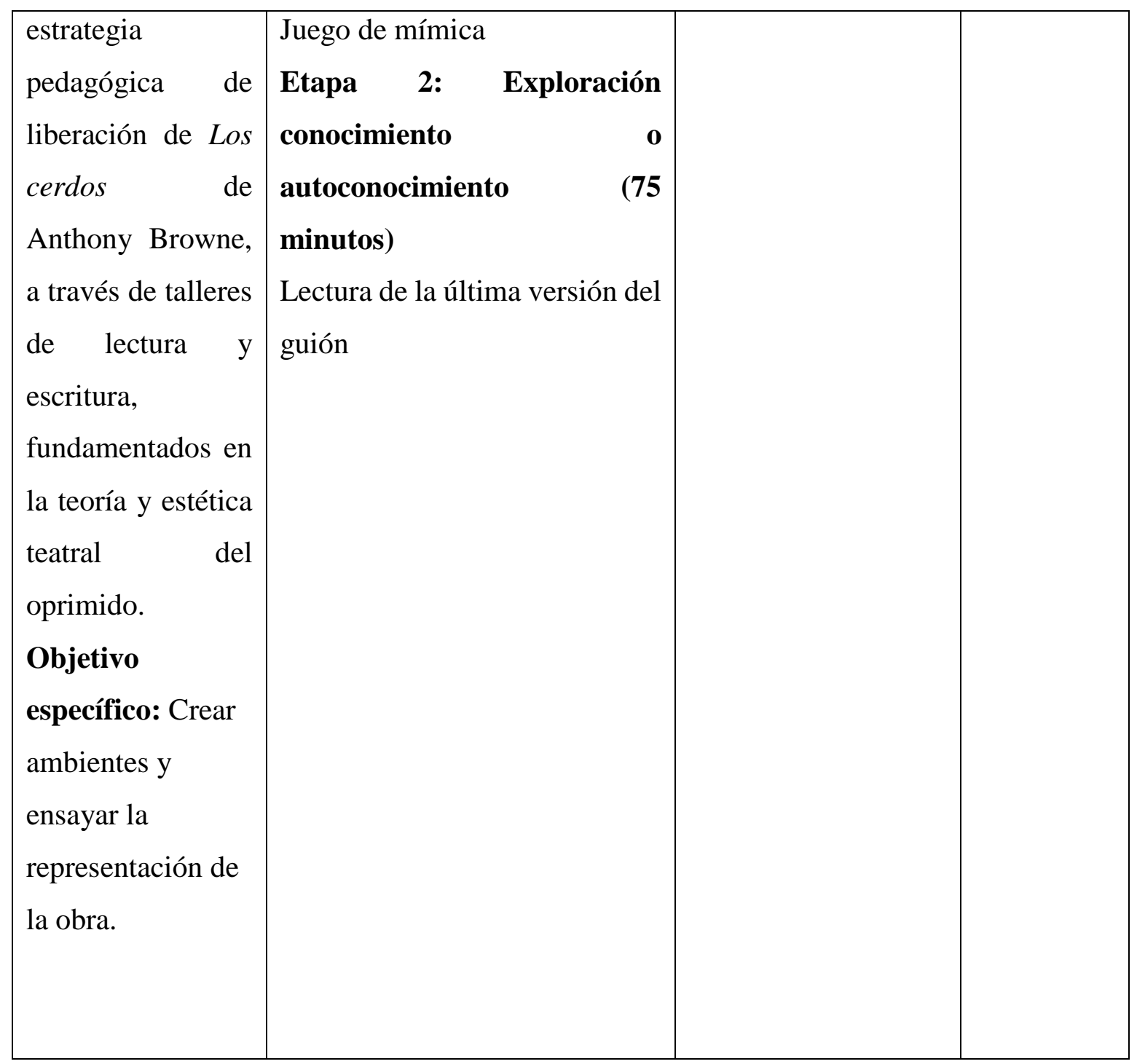

El día 28 de abril asistieron diecinueve niños. El taller inicia con un juego de mímica, un compañero le dice a otro en el oído un rol y él lo representa. 


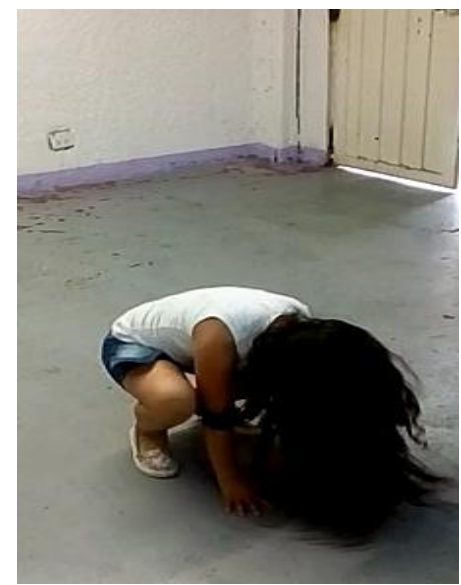

Objetivo 3. Taller No.9 Juego de mímica.

Después, se realizó la lectura colectiva de la segunda y última versión del guión.

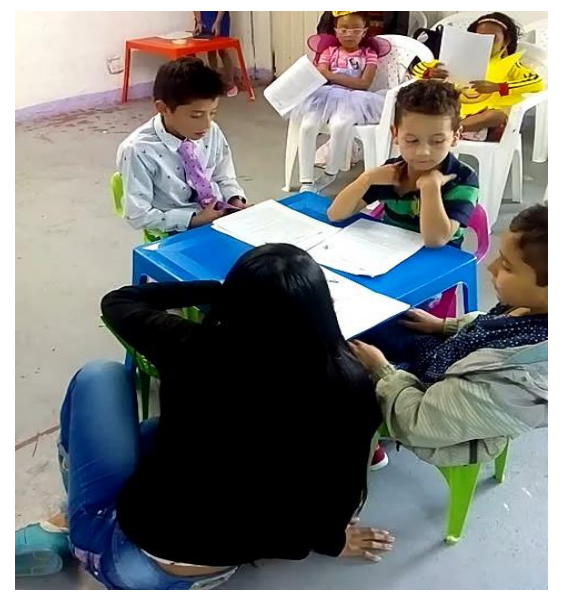

Objetivo 3. Taller No. 9 Lectura colectiva de la versión final del guión.

La recurrencia es la creación y su categoría es pensamiento crítico. Los niños por medio del guión plantearon sus ideas, opiniones y posturas frente a una problemática de la realidad y brindaron oportunas soluciones creando un mundo por medio de las palabras. Por lo tanto

La palabra instaura el mundo del hombre. La palabra, como comportamiento humano, significante del mundo, no solo designa a las cosas, las transforma; no es solo pensamiento, es “praxis”. Así, considerada la semántica es existencia y la palabra viva se planifica en el trabajo. (Freire, 2005, p.24)

\section{Taller No.10}

¡Listos, cámara, acción! II 


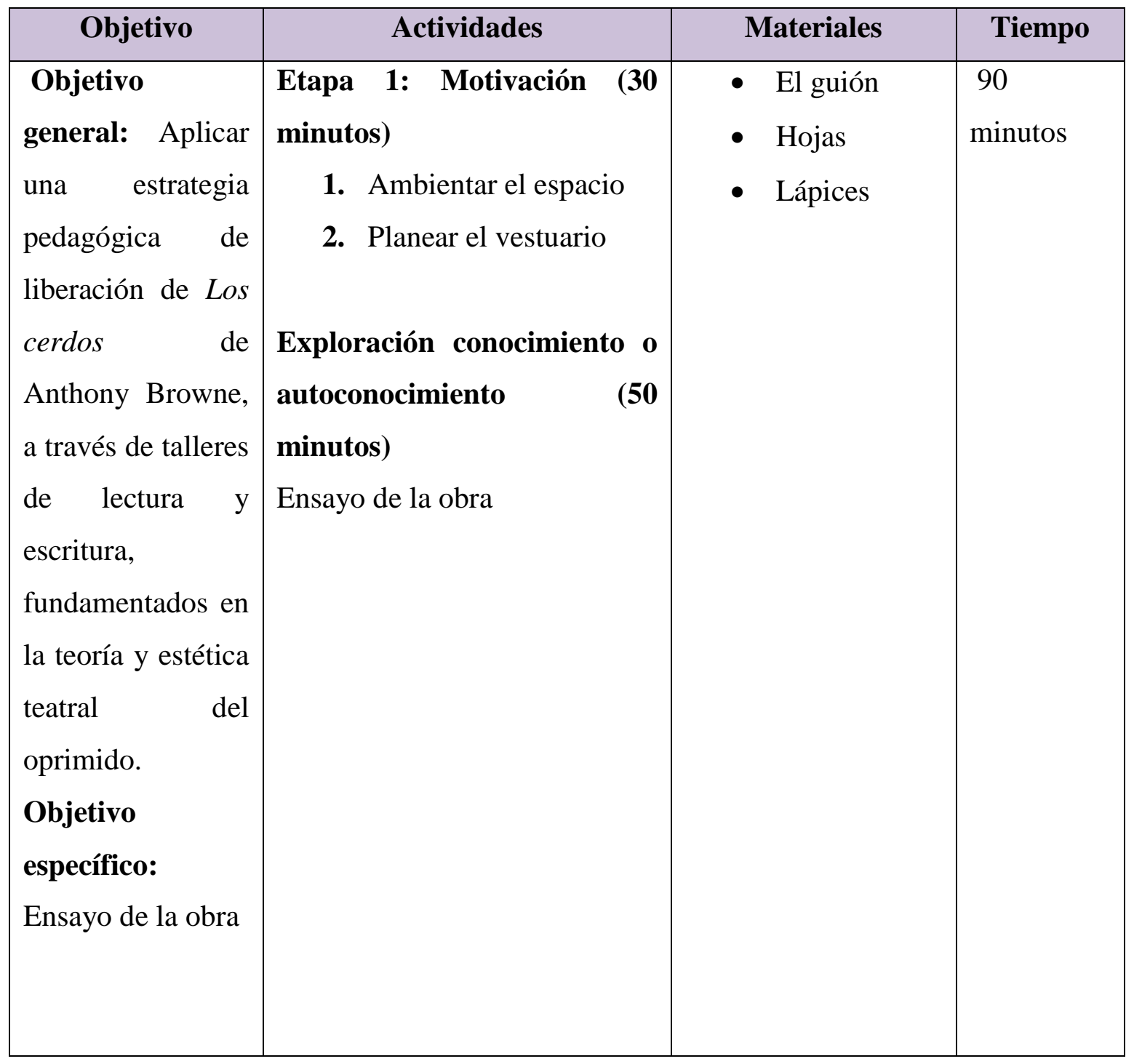

El día 5 de mayo asistieron diecinueve niños. El taller se desarrolló en dos momentos primero la planificación del vestuario de cada personaje y segundo la ambientación del espacio.

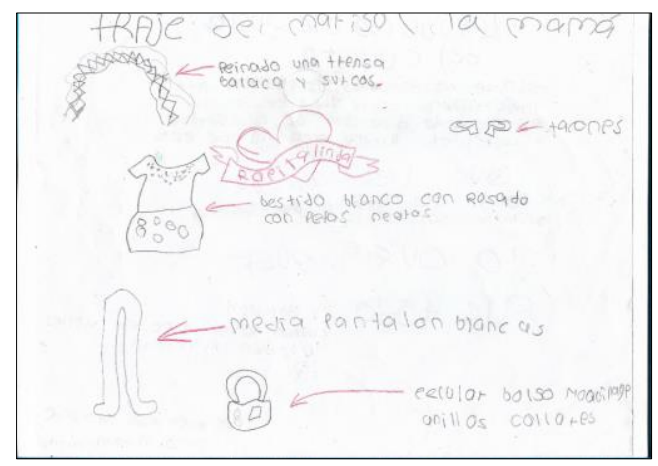


Objetivo 3. Taller No.10. Planeación del vestuario de los personajes.

Luego el ensayo de la obra de teatro

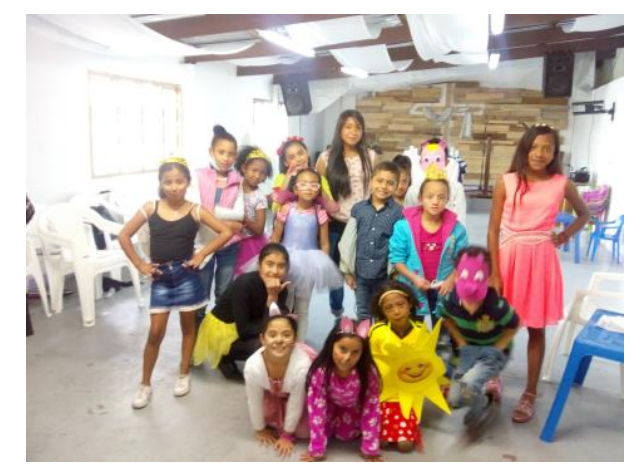

Taller No.10 Ensayo de la obra de teatro

La recurrencia es transformación y la categoría es Teatro del Oprimido. Los niños a través de sus ideas propuestas en el guión muestran su evolución a través del proceso, en escena manifiestan la transformación que han tenido por medio de la literatura y el teatro, por lo tanto:

La meta del Teatro del Oprimido no es llegar a un equilibrio tranquilizador, sino al desequilibrio que conduce a la acción. Su objetivo es dinamizar. Esto se consigue a través de la acción concreta, en escena: ¡el acto de trasformar es transformador! Transformando la escena, me transformo. Es en ese sentido en que podemos decir que la catarsis del Teatro del Oprimido es purificadora: nos purifica de nuestros bloqueos y ensancha los atajos que queremos tomar para transformar nuestra vida. (Boal, 2005, p. 95)

La catarsis purificadora la realizan en la obra de teatro demostrando una solución simbólica a una problemática real que se vive en el día a día en nuestra sociedad.

\section{Hallazgos}

\subsection{El universo de los niños del barrio Juan XXIII}

Objetivo 1 Caracterizar la población y su respectivo contexto para identificar la realidad sociocultural.

\section{Taller No.1 ¿Quién soy?}

Los niños a través del dibujo y la escritura se reconocen con sentimientos de felicidad y amor, aman a la naturaleza, además tienen aspiraciones artísticas y deportivas. Ellos 
realizan una lectura de su ser, por consiguiente, mediante su expresión artística y escrita permiten dejar en el papel su personalidad y sus sueños. Siendo evidente que las habilidades de lectura y escritura superan el nivel mecánico y sí van al lado de la realidad llegan a ser significativas en la vida del educando, por eso

el aprendizaje de la lectura y de la escritura, por eso mismo, no tendrá significado real si se hace a través de la repetición puramente mecánica de silabas. Ese aprendizaje es válido cuando, simultáneamente con el dominio de la formación de vocablos, el educando va percibiendo el sentido profundo del lenguaje: cuando va percibiendo la solidaridad que existe entre el lenguaje- pensamiento y la realidad, cuya transformación, al exigir nuevas formas de comprensión, plantea también la necesidad de nuevas formas de expresión. (Freire, 1998, p.55)

\section{Taller No.2 Compartiendo nuestro mundo familiar}

Los niños leen su ámbito familiar, teniendo como resultado diferentes clases de familias, sin embargo, plasman sentimientos positivos que los manifiestan por medio de la expresión artística y escrita porque esa es la lectura que hacen de su mundo, pasando a otro nivel de lectura y escritura. Éstas habilidades comunicativas son útiles en todos los contextos no solo en el educativo, así

Las escuelas tienden a olvidar que ellas son solamente uno de los contextos para el aprendizaje de la lectura y la escritura, así como tienden a concentrarse en determinados tipos de lecto-escritura y en el logro de las habilidades y no tienen en mente el papel que desempeñan en la manera que los estudiantes conceptualizan la lecto-escritura, incluyendo su valoración dentro y fuera de la escuela. Tampoco tienen en mente el alcance de las aplicaciones que hacen los estudiantes de la lectura y la escritura como parte de la "lógica de su vida diaria" (Frase de Szwed) (Ferreiro, 1982, p.339).

\section{Taller No. 3 Describiendo la imagen de mi barrio}

Los niños leen y escriben su entorno desde la felicidad, rescatando todo lo positivo que existe dentro de lo negativo. No importa su estructura lo que interesa es la amabilidad y solidaridad que hay entre vecinos, la calidad humana de las personas que habitan el espacio. Por ello,

La lectura del mundo no puede ser la lectura de los académicos impuesta a las clases populares. Ni tampoco puede tal lectura reducirse a un ejercicio 
complaciente de los educadores o educadoras en el cual, comprueba de respeto hacia la cultura popular, callen frente al "saber de experiencia vivida" y se adapten a él. [...]Es precisamente la "lectura del mundo" la que va permitiendo el desciframiento cada vez más crítico de la o de las "situaciones límite". (Freire, 1998, P. 102)

Con la lectura y la escritura de su barrio los niños muestran que son dueños de sus procesos de lectura y escritura, por lo tanto

Los niños conocen ya mucho sobre sí mismos como lectores y escritores. Ya han empezado a hacer suyo el proceso de alfabetización. Con frecuencia, las escuelas tienden a tomar el control y a quitar mucho de ese sentido de propiedad, ese sentido de tener confianza para experimentar con la escritura con muchos propósitos, y ese sentido de confianza para leer y explorar a través de la lectura. Negar las diferencias sociales y culturales y perseguir la uniformidad en las maneras de usar la lectura y la escritura y en las maneras de interacción en relación con el texto escrito, implicaría ignorar un potencial enorme para dar a los niños la oportunidad de llegar a ser "propietarios" de sus actividades de lectura y escritura. Las escuelas, al ignorar las diferencias, negarían a los niños la oportunidad de extender la definición de sí mismos como lectores y escritores, primero en su propia comunidad y después en la sociedad. (Ferreiro, 1982, p. 341)

\subsection{Habilidades comunicativas encontradas en los niños del barrio Juan XXIII}

Objetivo 2: Fomentar las habilidades comunicativas desde el cuento Los cerdos de Anthony Browne para que los niños desarrollen el placer, el gozo por la lectura y el lenguaje crítico.

\section{Taller No.4 Escribiendo para comprender}

Los niños luego de leer y comprender la lectura escriben lo que ellos harían en la situación del personaje del cuento. Van de la literatura hacia la realidad, realizan la lectura de la palabra y la lectura del mundo, tomando posición crítica a través de sus escritos. De esta manera 
Los sujetos capaces de lenguaje y de acción, pueden referirse a más de un mundo, y que al entenderse entre sí sobre algo en los dos mundos basan su comunicación en un sistema compartido de mundos [...] La acción comunicativa depende de contextos situacionales que a su vez son fragmentos del mundo de la vida de los participantes en la interacción. (Habermas, 2003, p. 358)

\section{Taller No.5 Improvisando ando}

La lectura del libro-álbum Los cerdos despierta el placer y el gozo por la literatura ya que se da una lectura no convencional. Dado que, "el álbum además de ser un libro, y por encima del libro que es, es algo más, es la plasmación de una forma de comunicación, basada en una forma de representación, que provoca un nuevo "modo de leer" (Banco del libroGRETEL, 2010, p. 187). Los niños leen las imágenes y siguen la secuencia narrativa del cuento mostrando su interés por la lectura, fomentando el placer hacia la literatura. Es un texto de goce ya que les plantea a los educandos una problemática que desacomoda su tranquilidad y los pone a pensar en su realidad. Así, como define Barthes,

Texto de placer: el que contenta, colma, da euforia; provienen de la cultura, no rompe con ella y está ligado a una práctica confortable de la lectura. Texto de goce: el que pone en estado de pérdida, desacomoda, hace vacilar los fundamentos históricos, culturales, psicológicos del lector, la congruencia de sus gustos, de sus valores y de sus recuerdos, pone en crisis su relación con el lenguaje. (2007, p. 25)

A partir del placer y el goce se puede decir que un niño "lee porque quiere saber qué pasa, no porque se lo han mandado. Lee por propia iniciativa, no por los demás (el maestro), ni por las notas que le ayudarían a hacer un buen papel”. (Rodari, 1973, p.126)

Leer y escribir son herramientas que permiten a los niños tener una adecuada compresión, interpretación y participación en el mundo. Los niños leen la problemática, su realidad, escriben las posibles soluciones a partir de la reflexión crítica y las expresan en escena.

\section{Taller No. 6 Conociendo el guion teatral}

La lectura y la escritura superan lo mecánico de los procesos, van más allá. Los niños pueden ser parte de la historia y darle un nuevo rumbo por sus habilidades comunicativas. También por las experiencias que ha tenido desde su realidad, ya que "la construcción social 
de tales experiencias les ofrece la oportunidad de dar significado y expresión a sus propias necesidades y voces, como parte de un proyecto de adquisición por sí y socialmente de facultades críticas" (Giroux, 1998, p.233)

La palabra posibilita la creación de un mundo ideal. Por lo tanto, no es válido decir que aprender a leer y a escribir son procesos mecánicos y rígidos sin sentido, teniendo en cuenta que

La alfabetización no es un juego de palabras, sino la conciencia reflexiva de la cultura, la reconstrucción, crítica del mundo humano, la apertura de nuevos caminos, el proyecto histórico de un mundo común, el coraje de decir su palabra. [...] Aprender a leer es aprender a decir su palabra. Y la palabra humana imita a la palabra divina: es creadora. [...] La palabra se entiende aquí como palabra y acción. Palabra viva y dinámica y no categoría inerte y no exánime. Palabra que dice y transforma el mundo. (Freire, 2005, p. 27)

\subsection{La estrategia del teatro del oprimido para fomentar las habilidades comunicativas}

Objetivo 3. Aplicar una estrategia pedagógica de liberación de Los cerdos de Anthony Browne, a través de talleres de lectura y escritura, fundamentados en la teoría y estética teatral del oprimido.

\section{Taller No. 7 Expresando nuestras opiniones}

Los niños crean personajes que ayudan a encontrar posibles soluciones a la problemática presentada por el cuento para la obra de teatro, expresando su pensamiento frente al mensaje que transmite el texto.

Creando los personajes los niños participan de la actividad teatral siendo "un instrumento eficaz para la compresión y la búsqueda de soluciones a problemas sociales e intersubjetivos. [...] El teatro del oprimido se desarrolla en cuatro aspectos fundamentales: artístico, educativo, político-social y terapéutico” (Boal, 2005, p.28)

\section{Taller No. 8 Produciendo nuestro guión teatral}


Los niños a partir de sus habilidades comunicativas complementan los diálogos de sus personajes manifestando su postura frente a la problemática. Demostrando que "el teatro del oprimido crea espacios de libertad donde la gente pueda dar rienda suelta a sus recuerdos, emociones, imaginación, pensar en el pasado, en el presente e inventar su futuro en lugar de sentarse a esperarlo de brazos cruzados" (Boal, 2002 p.14). Los niños participan en la solución del problema pensando cómo actuaría cada personaje pensando en un futuro. Incentivando al pensamiento crítico, pero para su desarrollo de debe formar en la pedagogía critica ya que

La pedagogía critica no se preocupa solamente de ofrecer a los alumnos y alumnas nuevas formas de pensar de manera crítica y de actuar con autoridad en las aulas, conscientes de su papel de agentes de cambio; también se preocupa de proporcionar a los alumnos y alumnas las habilidades y los conocimientos necesarios para que amplíen las capacidades, ya sea para cuestionar las suposiciones y los mitos fuertemente asentados que legitiman los hábitos sociales más arcaicos y restrictivos (que estructuran todos los aspectos de la sociedad) o para asumir su responsabilidad de intervenir en el mundo que habitan. (McLaren, 2008, p. 18)

\section{Taller No. 9 ¡Listos, cámara, acción! I}

Los niños leen motivados la creación colectiva de la adaptación teatral del cuento Los cerdos. Se sorprenden porque se dan cuenta que las habilidades comunicativas y el teatro les permite explorar otras dimensiones. Así como afirma Boal

El teatro es la primera invención humana, la que permite y promueve todos los demás inventos. El teatro nace cuando el ser humano descubre que puede observarse a sí mismo y, a partir de ese descubrimiento, empieza a inventar otras maneras de obrar. Descubre que puede mirarse en el acto de mirar; mirarse en acción, mirarse en situación. Mirándose, comprende lo que es, descubre lo que no es e imagina lo que puede llegar a ser. Comprende en donde está, descubre donde no está e imagina a donde puede ir. Se crea una composición tripartita: el yo-observador, el yo -en situación y el -posible (el no-yo, el Otro) (2004, p.25).

\section{Taller No.10 ¡Listos, cámara, acción! II}

Los niños ponen en escena el mundo creado a partir de la literatura, el teatro y las habilidades comunicativas. 


\subsection{Producto final: Guión teatral y puesta en escena}

Los niños en el proceso de la adaptación teatral del cuento crearon nuevos personajes que apoyaban la historia. Fueron creativos porque incluyeron seres fantásticos los cuales brindaban consejos a los protagonistas para tener un final satisfactorio.

Cada uno de los niños pensó en la problemática que trata el cuento y manifestaron su posición crítica aportando sus ideas al guion teatral, realizaron la construcción de una solución simbólica a través de la lectura del cuento, escritura del guion y puesta en escena de la obra.

En la puesta en escena los niños asumieron su papel con gran responsabilidad y consciencia que el mensaje fue claro para los padres de familia, en sus expresiones faciales demostraban la sorpresa por el mensaje significativo el cual sus hijos les estaban transmitiendo.

\subsection{Triangulación de toda la información}

En los talleres, el guión teatral y la puesta en escena se obtuvo el resultado del fomento de las habilidades comunicativas como lectura y escritura, el pensamiento crítico y la creatividad.

\section{Fomento de habilidades comunicativas}

En cada taller los niños leían una parte del cuento y realizaban la lectura de su mundo, escribían sobre la compresión lectora y su respectivo contexto.

El guión final fue el proceso de la lectura y escritura literaria y de sus realidades. Las ideas surgieron a partir de las habilidades comunicativas que se incentivaron en los talleres.

En la obra representada se demostró que para obtener ésta creación fue necesario un proceso de lectura literaria, escritura de un texto teatral y paralelamente un trabajo en la oralidad.

\section{Pensamiento crítico}

En los talleres los niños asumían una posición crítica frente a la problemática que se les presentaba a través del cuento, analizaban e interpretaban lo que leían, asimismo a través de sus escritos manifestaban su pensamiento. 
El guión teatral fue una creación colectiva del pensamiento crítico de cada uno de los niños porque se pusieron en situación, pensaron como actuarían en una problemática en su mundo y construyeron una solución simbólica por medio de la lectura de su mundo y la escritura del texto dramático.

La obra representada fue la puesta en escena del pensamiento crítico de cada uno de los niños, fue la actuación e interpretación de sus ideas.

\section{Creatividad}

Los niños en cada taller fomentaban la creatividad a través de la lectura del cuento, la escritura y la representación artística de su mundo.

En el guión teatral los niños demostraron la creatividad a partir de la creación de nuevos personajes en la historia.

En la obra representada se evidencio la creatividad desde la planeación del vestuario hasta la ambientación del escenario. Y la construcción de los personajes en escena.

\section{Conclusiones}

- Leer y escribir superan los procesos mecánicos. Los niños a partir del teatro y la literatura pudieron leer, comprender y narrar sus realidades, superando lo básico de las habilidades comunicativas. A través de la lectura y la escritura los sujetos reconocen una forma de poder para transformar la vida desde su individualidad y colectividad. También lograron exteriorizar sus sentimientos a partir de la lectura de su mundo en los diversos contextos como el familiar, social y educativo plasmándolo 
mediante la composición escrita y en algunos casos complementándolo con la expresión artística. Asimismo, manifestando su pensamiento crítico de la problemática planteada en el texto narrativo y construyendo posibles soluciones desde el teatro.

- El teatro y la literatura incentivan al desarrollo de las habilidades comunicativas. En literatura con el Libro de Los Cerdos de Anthony Browne se despertó en los niños el placer y el gozo por la lectura, primero por la estrategia lúdica como es el libro-álbum en el que se vuelve un juego los elementos gráficos y textuales para la comprensión del significado, ya que todo no es explicito entonces las imágenes y grafías se deben leer y analizar al tiempo para revelar lo que está oculto; segundo por la temática del cuento sobre el machismo que se conecta con sus vidas. En teatro los niños escribieron las posibles soluciones simbólicas a la problemática comprendida en el texto narrativo teniendo como resultado el guión teatral y por último la puesta en escena fomentando la expresión oral.

- La lectura y la escritura son significativas en los niños cuando se relacionan con su realidad porque al comprender la temática del cuento sobre el machismo, se pusieron en situación de los personajes conectándose con la problemática planteada leyendo y escribiendo con gran pasión las ideas para la creación del guión teatral, ya que han vivido esta situación en sus hogares y fue la única manera de poder pronunciar su voz, con la finalidad de ponerlo en práctica cuando estén en su vida cotidiana.

- Los niños obtienen un pensamiento crítico cuando leen y escriben su mundo. Son capaces de ir más allá de los procesos mecánicos, cuando leen su mundo lo comprenden y lo interpretan identificando las problemáticas que los rodean como en este caso el machismo que se vive en cada uno de los hogares, asimismo toman postura frente a la situación y crean soluciones para transformar sus realidades.

- Las habilidades comunicativas están presentes en todos los contextos no sólo en el educativo. Con el proyecto se evidencio que la lectura y la escritura hace parte de los ámbitos como lo son los familiares, sociales y culturales, gracias a los aportes de cada uno de ellos, se obtuvo como producto final la escritura colectiva del guión teatral desde sus vidas. 
- La literatura, el Teatro del Oprimido y las habilidades comunicativas permiten expresar el pensamiento de los individuos. Con la lectura literaria del texto del autor e ilustrador Anthony Browne los niños expresaron sus opiniones acerca de la problemática de género que existe en la sociedad, con el método de Augusto Boal manifestaron las soluciones simbólicas del machismo mostrando su reflexión y pensamiento crítico mediante la lectura de su mundo, la escritura del guión teatral y la expresión oral en la puesta en escena.

- El teatro posibilitó la imaginación y la creatividad de los niños porque abrió un espacio para ponerse en situación de los personajes como pensar, mirar, caminar, hablar como ellos, al mismo tiempo tuvieron la libertad de construirlo desde sus aspectos personales y en concreto con el método de Boal asumiendo los roles asignados, pero al mismo tiempo cuestionándolos y transformándolos con base a la reflexión crítica de su mundo.

- Las habilidades comunicativas permiten obtener una reflexión y un pensamiento crítico de la realidad. La lectura ayudó a los niños a comprender e interpretar su mundo y la escritura brindo la posibilidad de exteriorizar su postura frente a los problemas que se presentan en su vida diaria, en este caso específico el machismo, escribieron lo que piensan acerca de la injusticia de género y como contribuirían para darle una solución oportuna a la desagradable situación que ha sido vivida durante años, demostrando el deseo por ser agentes de cambio para erradicar la problemática, como se puede evidenciar en el guión teatral Un mundo de cerdos.

\section{Referencias Bibliográficas}

Acosta, Carmen Elisa. (2011) Pensar la literatura infantil, interpretación varias voces. Corcas Editores. Bogotá. 
Arenas DelgadoChristian.Lo narrativo y visual de "Voces en el parque": una propuesta didáctica interdisciplinaria en el aula de secundaria Universidad Autónoma de Barcelona. Baraúna, Tânia. (2011) Pedagogía del Oprimido para un teatro social creativo.Novum - 2a Época - No 1 - Periodicidad: anual.

Banco del libro-GRETEL. (2010) Cruce de miradas: Nuevas aproximaciones al libroálbum. Barcelona.

Barthes, Roland. (1994) El susurro del lenguaje. Más allá de la palabra y de la escritura. Editorial Paidós. Barcelona.

Barthes, Roland. (2007) El placer del texto.Siglo XXI editores. México

Boal, Augusto (2002) Juegos para actores y no actores. Alba editorial. Barcelona.

Boal, Augusto (2012) La estética del oprimido. Alba editorial, Barcelona.

Boal, Augusto (2009) Teatro del oprimido. Alba editorial, Barcelona.

Castro Contreras, Mary Nelcy. (2008) Juego dramático como estrategia didáctica que facilita el proceso de producción de textos en los estudiantes del grado quinto de la Fundación Nueva Granada. Universidad san buenaventura. Facultad de educación. Especialización en didácticas para lecturas y escrituras con énfasis en literatura. Bogotá. Carrillo García Deisy Constanza. (2012)El teatro como estrategia didáctica para incentivar la lectura. Universidad Libre. Facultad ciencias de la educación. Licenciatura en educación básica con énfasis en humanidades e idiomas. Bogotá.

Cassany, Daniel. (2006) Taller de textos leer, escribir y comentar en el aula. Ediciones Paidós de Ibérica. Barcelona.

Cassany, Daniel. (1999) Construir la escritura.Ediciones Paidós de Ibérica. Barcelona.

Castaño ArbeláezLyda.(2015) La lectoescritura apoyada en el teatro como estrategia pedagógica en estudiantes de grados décimo y once de la institución educativa Casd. Fundación universitaria los libertadores. Facultad de ciencias de la educación.

Cortés García, Alba Julieth. (2001) El teatro como estrategia pedagógica para la expresión escrita. Nómadas. Universidad Central Bogotá, Colombia

Díaz Rodríguez, Cecilia. Escala de Machismo Sexual (EMS-Sexismo-12): diseño y análisis de propiedades psicométricas Universidad Autónoma de Nuevo León. 
Escobar, Miguel. (1985) Paulo Freire y la educación liberadora. Secretaria de Educación Pública. México.

Escobar Mariela. Vallette Paula. (2015) Teatro foro como medio para complejizar la mirada delconflicto y las relaciones en el aula. Universidad Academia de Humanismo Cristiano. Santiago. Chile.

Freire, Paulo. (2004) La importancia de leer y el proceso de liberación. Siglo XXI editores. México

Freire, Paulo. (2005) La pedagogía del oprimido. $2^{\mathrm{a}}$ Edición. México. Editores S.A de C.A. Freire, Paulo (1994) La pedagogía de la esperanza. Siglo XXI editores México.

Fajardo María Delia. (2014) El potencial didáctico del libro-álbum para la educación literaria-intercultural.

Ferreiro, Emilia. Teberosky, Ana (1998) Los sistemas de escritura en el desarrollo del niño.

Ferreiro, Emilia. Gómez, Margarita. (1982) Nuevas perspectivas sobre los proceso de lectura y escritura. Siglo XXI editores. México

García Márquez, Gabriel. (1995) Manual para ser niño.

Giroux A. Henry. (1998) La escuela y la lucha por la ciudadanía. Pedagogía crítica de la época moderna. Siglo XXI editores. México.

Habermas, Jürgen. (2003) Teoría de la acción comunicativa I. Racionalidad de la acción y racionalización social. Santillana Ediciones Generales, S.L. Madrid.

Homs, Marc. (2013)El teatro del oprimido como herramienta socioeducativa para la integración social en el aula en 1 de ESO. Universidad Internacional de la Rioja.

Barcelona

Ibarzabal Rivas, Miren. (2015) El teatro del oprimido como herramienta de trabajo del educador social en los centros menores. Facultad de educación. Universidad de Valladolid.Palencia. España.

Jara, Oscar. (1996) Sistematización. Recientes búsquedas. Bogotá: Revista dimensión educativa.

López González María Teresa. (2008)La Pedagogía Teatral ¿Una estrategia para el desarrollo del Autoconcepto en niños y niñas de segundo nivel de transición? Universidad De Chile Facultad De Ciencias Sociales Departamento De Educación. Santiago, Chile. 
López Quintanas Alfonso. (1997) Estética de la creatividad. Juego. Arte. Literatura. Ediciones cátedra s.a. Madrid.

Manrique, Andrea. (2015) El teatro social, una metodología creativa para el cambio. Universidad de Valladolid. Facultad De Educación y Trabajo Social España.

Marín, Noelia Pérez. (2016) Análisis de una obra literaria. Literatura Infantil y Juvenil $2^{o}$

Curso Grado Magisterio Primaria José Antonio García Fernández

McLaren, Peter. (2008) Pedagogía crítica. De qué hablamos, dónde estamos. Editorial GRAÓ de IRIF. Barcelona.

Mejía, Marco Raúl, (2008) La Sistematización. Empodera y produce saber y conocimiento. Bogotá: Ediciones desde abajo.

Ministerio de Educación Nacional (2011)Plan nacional de lectura y escritura de educación inicial, preescolar, básica y media.

Ministerio de Educación Nacional(2016)Ambientes escolares libres de discriminación. Orientaciones sexuales e identidades de género no hegemónicas en la escuela. Aspectos para la reflexión. Fondo de Población de las Naciones Unidas. Bogotá, D.C.

Molina Maritza (2005) Teatro del oprimido una herramienta de intervención social.

Universidad Austral de Chile. Facultad de Filosofía y Humanidades. Escuela de Lenguaje y Comunicación.

Motos, (2009). DeFreireaBoal:Pedagogíadel Oprimido---Teatrodel

Oprimido,CiudadReal:Ñaque.

OrtizMaialen. El álbum ilustrado: el libro de los cerdos de AnthonyBrowne.Universidad de Cantabria. Facultad de educación.

Parra Sierra, A. (2009)Estrategias lúdicas pedagógicas para mejorar el desempeño lector y escritor de los estudiantes de tercero de básica primaria de la institución educativa José Antonio Ricaurte. Ibagué.

Páez, Aulestia Celestina. (2013)El teatro del oprimido de Augusto Boal como herramienta de intervención social comunitaria. Universidad Complutense de Madrid. España.

Ramírez, Miguel. (2016) El teatro como herramienta para la intervención social: una aproximación desde el trabajo social. Universidad de Valladolid. España.

Rodari, Gianni. (1983) La gramática de la fantasía. Editorial Argos Vergara, S. A. Barcelona. 
Sánchez Bonilla., Leidy. El Teatro, actuación creativa, una estrategia para potenciar la competencia comunicativa de los estudiantes de grado tercero de primaria (301) de la Institución Educativa IED Tomás Carrasquilla jornada tarde. Universidad Pedagógica Nacional. Facultad de humanidades. Departamento de lenguas Licenciatura En Español E Inglés Bogotá, D.C. 2013.

Torre, Saturnino. (1982) Educar en la creatividad. Recursos para desarrollar la creatividad en el medio escolar. Narcea, S.A. Ediciones. España.

Uzcátegui, Rosa. (2004)El teatro como estrategia facilitadora de la lengua en niños con dificultades en aprendizaje. Universidad Nacional Abierta.

Vela Soraya. 2013. Análisis de las unidades semánticas en el libro álbum Willy, el tímido de Anthony Browne. Universidad técnica particular de Loja. La universidad católica loja. Área socio-humanístico

\title{
Anexos
}

\author{
Anexo 1 \\ Ficha general \\ PLAN JUAN XXIII 2018
}

Datos del responsable del hogar 
1. ¿Quién es la persona que está a cargo del hogar o grupo familiar? Nombre:
a. Edad:
b. Estado Civil:
c. No. de documento de identidad:
d. Fecha y lugar de nacimiento:
e. Género y etnia, especificar:
f. Nivel de escolaridad (marcar con X):
f.1. Ningún grado:
f.3. Educación media
f.2. Estudios Primarios Finalizado y o secundaria__ finalizada
f.4. Educación Técnica___, especificar en qué área:
f.5. Estudios superiores universitarios especificar área:
f.6. Otros estudios especificar área
g. Ocupación actual:
h. Tiene Seguridad Social que cubra salud especificar, ¿̇cuál?
i. Cuáles son sus ingresos mensuales promedio (marcar con una $\mathrm{x}$ ):
i.1. Menos de un salario mínimo
i.3. Más de un salario mínimo
i.2. Un salario mínimo
j. Presenta alguna incapacidad física o mental
i.4. Ninguno
k. Cuál es la creencia religiosa predominante (marcar con una $\mathrm{x})$ :
k.1. Católica
k.2. Cristiana
k.3. Protestante
k.4. Otra, ¿̇cuál?

\section{Datos de la familia y el o los menores a cargo}

2. Información grupo familiar
a. Cuantas personas viven en el hogar:
b. Cuantos menores están a su cargo (diligenciar datos para cada uno):

b.1 Nombre (s):

b.2.Edad(es):

b.3.Documento de identidad:

b.4. Nivel de escolaridad:

b.5. Interés artístico y académico de los menores (marcar con $\mathrm{X}$ ):
a. Deporte
b. Teatro
c. Lectura y escritura
d. Matemáticas
e. Inglés
f. Música
g. Otras, ¿cuáles?

b.6. ¿Qué les gusta hacer en su tiempo libre, especificar?

b.7. ¿En qué colegio o instituto estudia, y en qué jornada?

b.8. ¿Cómo es el rendimiento del niño en el colegio, especificar si es (marcar con X): bueno , regular , deficiente

b.9. Le gusta al niño ir al colegio.

b.10. ¿Los menores han participado en el Programa de Proyección social con las universidades? ¿Sí o no? ¿En cuál programa y cuándo? 
b.11. ¿Cuál percibe que es el sueño a futuro del o los menores, especificar?

b.12. ¿Apoyaría que el menor participe en el Programa de Proyección Social para capacitación, sí o no?

¿Por qué?

b.13. El Programa de Proyección Social, tiene también cobertura para mujeres en:

a. Sistemas b. manualidades c. cocina d. ejercicio físico,

f. ¿Estaría interesada en participar, en que capacitación, especificar?

c. ¿Existe en el hogar algún problema de consumo de sustancias psicoactivas? Especificar (marcar con $\mathrm{x}$ )

c.1. Consumo de tabaco____ C.2. Consumo de alcohol

c.3. Otras sustancias, ¿cuáles?

d. ¿Existe en el hogar algún problema de violencia, sí o no? , especificar (marcar con $\mathrm{x})$ :

d.1. Intrafamiliar, especificar

d.2. De género, especificar

d.3. infantil, especificar

d.4. Pandillas

e. ¿Tienen acceso a Seguridad Social, sí o no? —u especificar entidad

f. ¿Existen en el hogar embarazos de menores de edad, sí o no? _—_ especificar cuál Decir la edad del menor

g. Si existen personas desplazadas en el hogar, sí o no, , especificar

h. Si existen personas desmovilizadas en el hogar, sí o no, especificar

\section{Datos de infraestructura y contacto}

1. Tipo de vivienda (señalar $\operatorname{con} X$ )
a. Casa
b. Cuarto
c. Apartamento
d. Inquilinato o casa multifamiliar
d. Otros, especificar

2. La vivienda es (marcar con $\mathrm{X}$ ):
a. En arriendo
b. Propia
c. Otros, especificar

3. Cobertura de servicios básicos, especificar (marcar con X).
a. Agua
b. Alcantarillado
f. Telefonía fija
g. Telefonía móvil
c. Luz
d. Gas
g. Recogida de basura

4. Datos de domicilio:
a.Dirección:
b. Teléfonos Fijo y/o móvil:
c. Correo electrónico

Anexo 2 


\section{CONSENTIMIENTO INFORMADO}

Usted ha sido invitado(a) a participar en, el proyecto El teatro del oprimido como estrategia para fomentar las habilidades comunicativas de niños y niñas del Centro de Proyección Social Santo Domingo; con base en el texto Los Cerdos de A. Browne que tendrá lugar desde el 10 de Febrero de 2018 hasta el 28 de Abril de 2018. Recuerde que el objetivo principal de esta actividad es contribuir a fomentar la competencia comunicativa.

La Maestría en Estudios Literarios de la Universidad Santo Tomás, sede Bogotá, y El Centro de Proyección Social Santo Domingo, le agradece su participación voluntaria y le solicita, muy respetuosamente y cordialmente, por favor, nos permita grabar su voz y su imagen; es nuestro deseo conservar memoria de esta actividad. Deseamos realizar el proyecto El teatro del oprimido como estrategia para fomentar las habilidades comunicativas de niños y niñas del Centro de Proyección Social Santo Domingo; con base en el texto Los Cerdos de A. Browne sin ningún fin comercial ni ánimo de lucro. Este material será única y exclusivamente para uso cultural y artístico, y no le someterá a ningún tipo de riesgo físico ni psicológico; beneficiará principalmente a los niños y niñas.

La aceptación y firma de este consentimiento informado, le compromete a colaborar para una adecuada recolección de fotografías y vídeos. Toda la información obtenida será cuidadosamente tratada, en caso de ser utilizada para alguna presentación de la institución organizadora y financiadora.

Usted tiene derecho a no aceptar, y a manifestar que no desea que le tomen fotos ni le graben, siempre y cuando lo comunique por escrito oportunamente a alguno de nuestros coordinadores. Antes de firmar, puede hacer todas las preguntas y solicitar las aclaraciones que considere necesarias.

Al firmar el presente consentimiento, usted no se compromete a nada adicional a lo estipulado anteriormente.

Declaro haber leído el presente formato de consentimiento y haber recibido respuesta satisfactoria a todas las inquietudes y preguntas que he formulado, antes de aceptar voluntariamente mi participación en este proyecto.

Nombre:

Firma:

Lugar y Fecha: 


\section{Anexo 3}

\section{DIARIO DE CAMPO No.1}

\begin{tabular}{|c|c|}
\hline Docente: & Sandra Paola Ramos Moreno \\
\hline Taller: & Conociéndonos \\
\hline Fecha: & Febrero 17 de 2018 \\
\hline Hora: & $10: 30$ a.m. a $12: 00$ p.m. \\
\hline
\end{tabular}

DIARIO DE CAMPO No.2

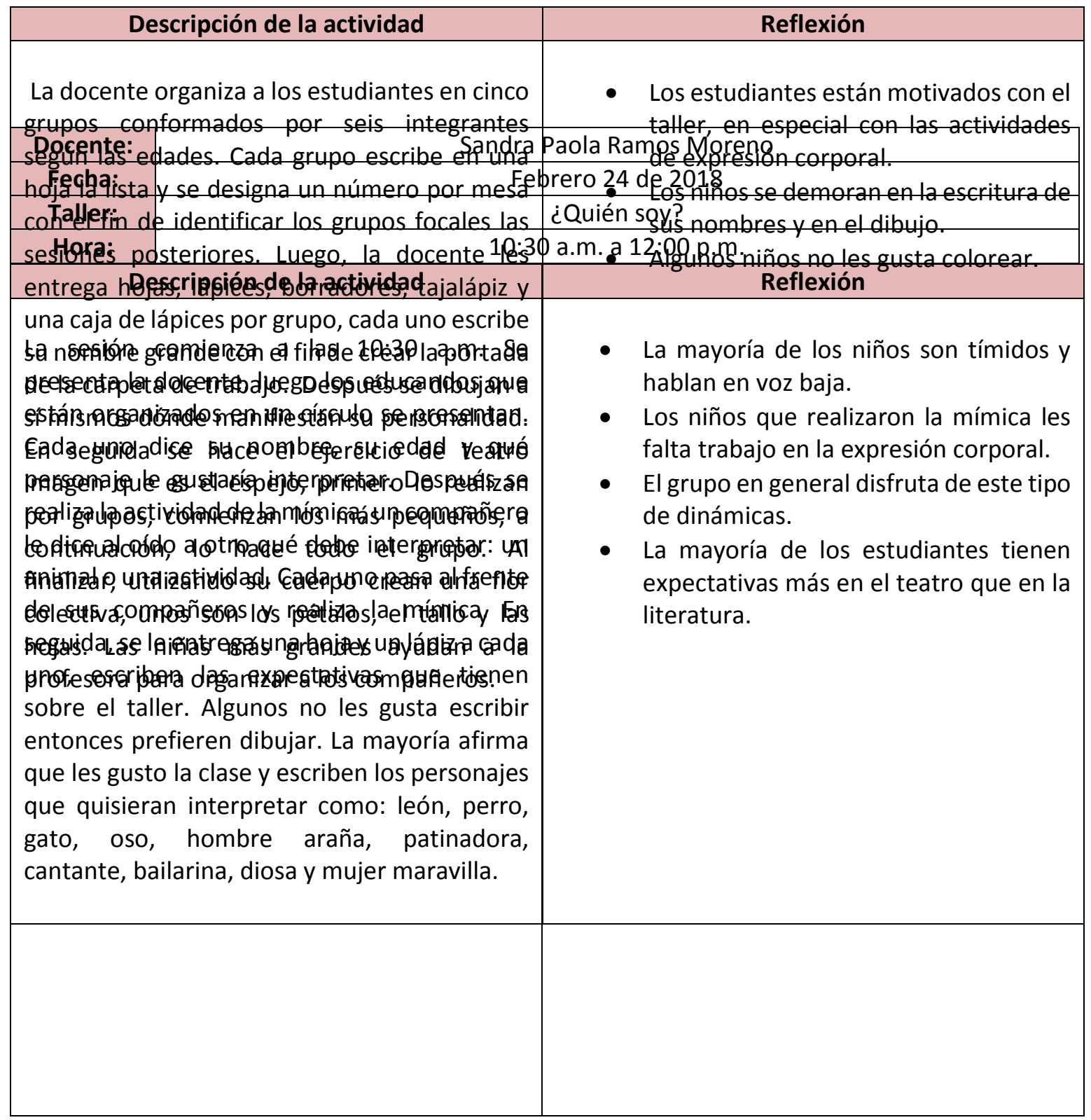




\begin{tabular}{|c|c|}
\hline Docente: & Sandra Paola Ramos Moreno \\
\hline Taller: & Compartiendo nuestro mundo familiar \\
\hline Fecha: & Marzo 3 de 2018 \\
\hline Hora: & $10: 30$ a.m. a $12: 00$ p.m. \\
\hline
\end{tabular}

DIARIO DE CAMPO No.3

\begin{tabular}{|c|c|}
\hline Descripción de la actividad & Reflexión \\
\hline $\begin{array}{l}\text { Los estudiantes se organizan en los respectivos } \\
\text { grupos, la docente entrega las carpetas para } \\
\text { que las observen. Después se presenta la obra } \\
\text { literaria de Los Cerdos de Anthony Browne y } \\
\text { realizan la lectura visual, describen la imagen, } \\
\text { dicen los colores, las personas que están allí y } \\
\text { los estados de ánimo que tienen. Luego } \\
\text { formulan hipótesis con la lectura de la imagen } \\
\text { y el titulo Los Cerdos, cómo son: "son } \\
\text { cochinos" "es el apellido de la familia" "La } \\
\text { mamá carga a los cerdos porque la cogen de } \\
\text { esclava" "se volvieron cerdos" "no les gusta } \\
\text { hacer nada". Luego, la docente entrega hojas, } \\
\text { lápices, borradores, tajalápiz y una caja de } \\
\text { lápices por grupo para que cada niño dibuje a } \\
\text { su familia. Se identifican cuatro tipos de } \\
\text { familia, la primera: niños que viven con sus } \\
\text { padres y hermanos, la segunda: hijos únicos } \\
\text { que viven con sus padres, la tercera: niños que } \\
\text { solo viven con la madre, la cuarta: niños que } \\
\text { viven con la madre o el padre y otros familiares } \\
\text { como: abuela, tíos y primos. Al mismo tiempo } \\
\text { la docente pregunta a algunos niños sobre sus }\end{array}$ & $\begin{array}{l}\text { - Los niños cumplieron con todas las } \\
\text { actividades propuestas, pero por falta } \\
\text { de tiempo las improvisaciones quedan } \\
\text { pendiente para la próxima clase. } \\
\text { - Se presentó agresión física entre los } \\
\text { niños por intolerancia y no respeto al } \\
\text { otro. Evidenciado que los niños } \\
\text { agresores tienen conductas violentas y } \\
\text { no les importa la integridad del } \\
\text { prójimo. Reproducen } \\
\text { comportamiento de su entorno. } \\
\text { Los niños quedan afectados por las } \\
\text { situaciones vividas que las vuelven a } \\
\text { recrear en la experiencia teatral. } \\
\text { Los niños tienen facilidad para la } \\
\text { improvisación y les gusta actuar. } \\
\text { Fueron organizados y receptivos. }\end{array}$ \\
\hline
\end{tabular}




\begin{tabular}{|l|l|}
\hline familias y ellos dicen: "son felices, regañones, \\
bravos" "Me tratan más o menitos, porque \\
cuando no hago nada me gritan" "Son felices, \\
divertidos y relajados" "Son amables y \\
cariñosos". Se interrumpe la actividad porque \\
en la mesa de los niños más pequeños se \\
presentan agresión física por dos educandos. \\
Se soluciona el problema y se continúa con la \\
clase. En los grupos establecidos se planea la \\
improvisación sobre la familia. Improvisa el \\
primer grupo y representa lo que acababa de \\
pasar en la clase, la profesora enseñando a leer \\
a los niños, es interrumpida por la pelea por \\
dos compañeros, los lleva a la rectoría, la \\
directora los anota en el observador y llama a \\
la mamá. La mamá llega al colegio y se los lleva \\
para la casa, allá les pregunta por qué se \\
comportaron de esa forma. El siguiente grupo \\
presenta su improvisación: llega la familia a un \\
restaurante, la mesera les toma el pedido, la \\
mamá dice "Después de esto vamos a ir a la \\
iglesia como la familia unida que somos" \\
comen, la mesera trae la cuenta y se van. \\
Las demás improvisaciones quedan pendientes \\
para la siguiente clase. \\
\end{tabular}




\begin{tabular}{|c|c|}
\hline Docente: & Sandra Paola Ramos Moreno \\
\hline Fecha: & Marzo 10 de 2018 \\
\hline Taller: & Describiendo la imagen de mi barrio \\
\hline Hora: & $10: 30$ a.m. a 12:00 p.m. \\
\hline Docente: & Sandra Paola Ramos Moreno \\
\hline Fecha: & Marzo 17 de 2018 \\
\hline Taller: & Improvisando ando \\
\hline Hora: & $10: 30$ a.m. a 12:00 p.m. \\
\hline
\end{tabular}

DIARIO DE CAMPO No.4

DIARIO DE CAMPO No.5

\begin{tabular}{|c|c|}
\hline Descripción de la actividad & Reflexión \\
\hline $\begin{array}{l}\text { El taller comienza con las improvisaciones que } \\
\text { habían quedado pendientes de la clase } \\
\text { anterior. Un grupo representa una familia que }\end{array}$ & $\begin{array}{l}\text { - Algunos niños se les dificulta la lectura } \\
\text { en voz alta. } \\
\text { - Realizan hipótesis validas desde su }\end{array}$ \\
\hline Descripción de la actividad & Reflexión \\
\hline 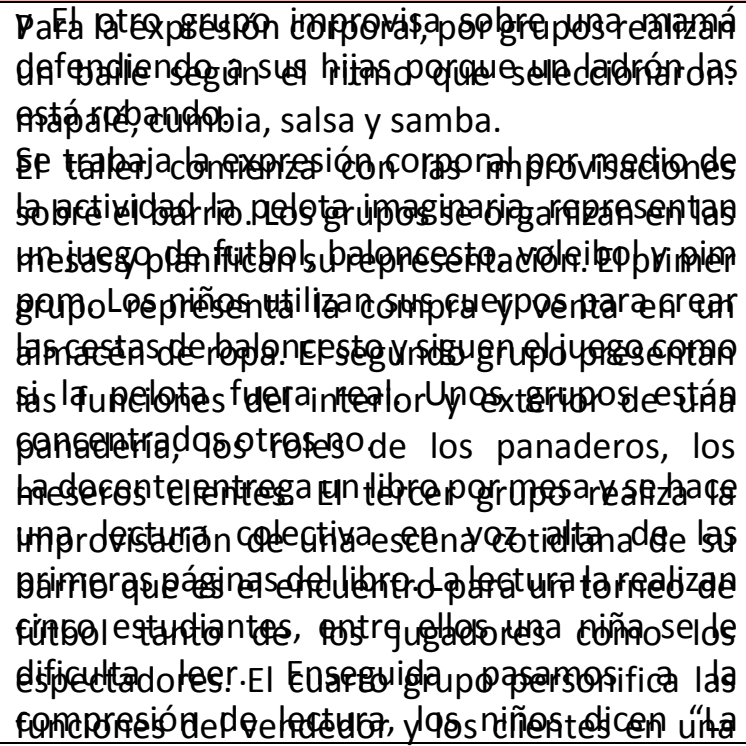 & 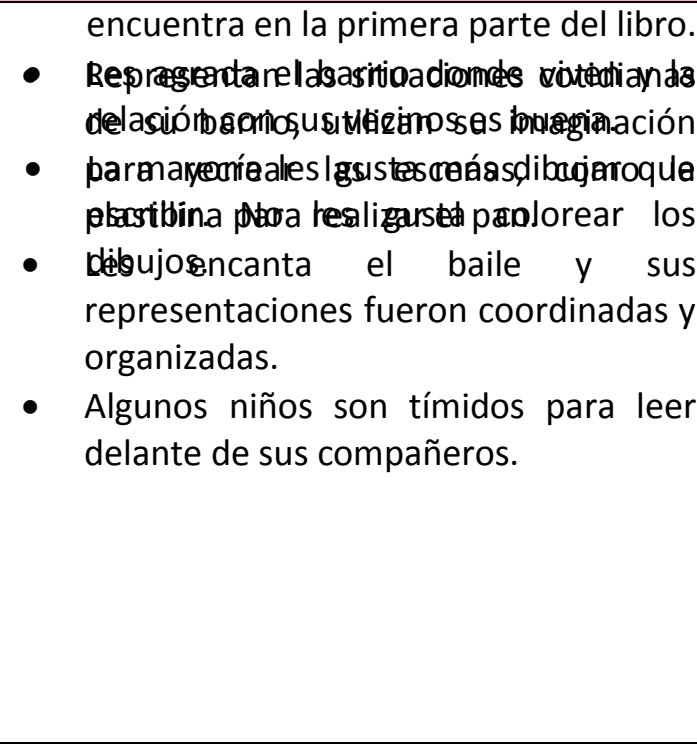 \\
\hline
\end{tabular}




\begin{tabular}{|c|c|}
\hline 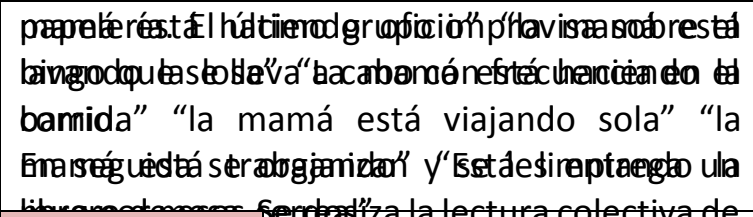 & \\
\hline 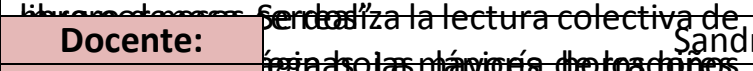 & a Paola Ramos Moreno \\
\hline Fecha: & Marzo 24 de 2018 \\
\hline Taller: & ciendo el guión teatral \\
\hline Hora: & 30 a.m. a 12:00 p.m. \\
\hline 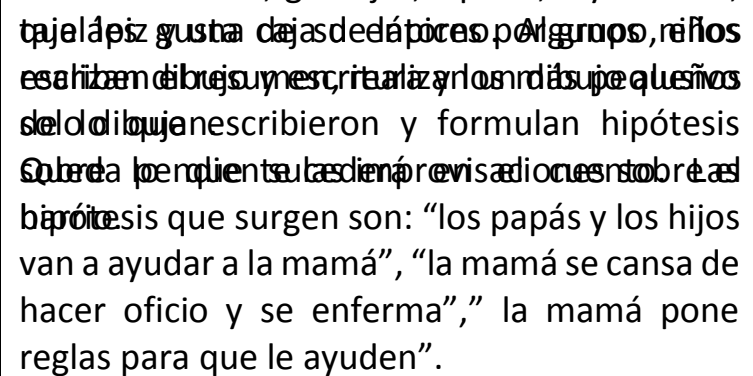 & \\
\hline & \\
\hline
\end{tabular}

DIARIO DE CAMPO No.6

\begin{tabular}{|l|l|}
\hline \multicolumn{1}{|c|}{ Descripción de la actividad } & \multicolumn{1}{|c|}{ Reflexión } \\
\hline $\begin{array}{l}\text { Los educandos se organizaron por grupos, para } \\
\text { realizar la actividad de expresión corporal que } \\
\text { es la carretilla. Los niños se divirtieron y fueron } \\
\text { muy hábiles en el juego porque ya la conocían } \\
\text { compitieron entre ellos de una forma pacífica. }\end{array}$ & $\begin{array}{l}\text { - Los niños han evolucionado en su } \\
\text { expresión teatral. }\end{array}$ \\
$\begin{array}{l}\text { Se realiza la lectura colectiva de las siguientes } \\
\text { compresión del cuento. }\end{array}$ \\
$\begin{array}{l}\text { páginas del cuento. Luego por grupos } \\
\text { improvisan sobre lo que comprendieron de la } \\
\text { lectura. Samuel es un niño que no quiere } \\
\text { trabajar en grupo, sin embargo, realiza la la } \\
\text { representación sólo, personifica el rol del papá } \\
\text { hasta convertirse un cerdo. Todos quedamos }\end{array}$ \\
\hline
\end{tabular}




\begin{tabular}{|c|c|c|}
\hline $\begin{array}{l}\text { muy sorpren } \\
\text { demás grupo } \\
\text { le agregan } \\
\text { continuar. }\end{array}$ & $\begin{array}{l}\text { os porque lo hizo muy bien. Los } \\
\text { nprovisan lo que entendieron y } \\
\text { que consideran que va a }\end{array}$ & \\
\hline $\begin{array}{l}\text { Ladonantas } \\
\text { Docente: }\end{array}$ & rega hojas, lápices, borradores, Sand & a Paola Ramos Moreno \\
\hline Fecha: & aja de taptces por grupo, ellos & Abril 7 de 2018 \\
\hline Taller: & Expres & indo nuestras opiniones \\
\hline Hora: & 10 & 30 a.m. a $12: 00$ p.m. \\
\hline
\end{tabular}

\section{DIARIO DE CAMPO No.7}

\begin{tabular}{|l|l|}
\hline \multicolumn{1}{|c|}{ Descripción de la actividad } & \multicolumn{1}{|c|}{ Reflexión } \\
\hline $\begin{array}{l}\text { Se realiza la actividad de expresión corporal “la } \\
\text { estatua de sal” los niños lo comparan con un } \\
\text { juego que se llama "cogidas" popularmente, } \\
\text { juegan y se divierten. }\end{array}$ & $\begin{array}{l}\text { - Hay poca asistencia de los niños por } \\
\text { problemas de la comunidad, pero los } \\
\text { niños que asisten están motivados al } \\
\text { conocer qué es el guión teatral y } \\
\text { representar una escena. }\end{array}$ \\
$\begin{array}{l}\text { el ejemplo con la primera escena del cuento. } \\
\text { Se seleccionan seis niños para que representen } \\
\text { al papá, la mamá y los hijos, se incluye a un } \\
\text { nuevo personaje con el fin que los niños vean } \\
\text { que es una adaptación. Los niños leen sus } \\
\text { diálogos y representan la escena. En seguida } \\
\text { los demás se entusiasman y quieren } \\
\text { representar los demás grupos. } \\
\text { Luego, se realiza la lectura colectiva de las } \\
\text { penúltimas páginas del cuento. La docente } \\
\text { entrega hojas, lápices, borradores, tajalápiz y } \\
\text { una caja de lápices por grupo, ellos escriben }\end{array}$ & \\
\end{tabular}




\begin{tabular}{|c|c|c|}
\hline \multicolumn{2}{|c|}{$\begin{array}{l}\text { cuál personaje quisieran representar y lo } \\
\text { dibujan. Al finalizar socializan su escrito. }\end{array}$} & \\
\hline Docente: & \multicolumn{2}{|c|}{ Sandra Paola Ramos Moreno } \\
\hline Fecha: & & Abril 14 de 2018 \\
\hline Taller: & Cond & ciendo el guión teatral \\
\hline Hora: & 10: & 30 a.m. a 12:00 p.m. \\
\hline
\end{tabular}

\section{DIARIO DE CAMPO No.8}

\begin{tabular}{|c|c|}
\hline Descripción de la actividad & Reflexión \\
\hline $\begin{array}{l}\text { Se realiza la actividad del bosque de sonidos, } \\
\text { concluyendo que los niños no siguen bien las } \\
\text { instrucciones del juego. Luego, por mesa se les } \\
\text { entrega un libro, comienza la lectura colectiva. } \\
\text { La docente solicita que cuando un estudiante } \\
\text { vaya a leer se levante de su silla y mejore su } \\
\text { tono de voz. Finalizan la lectura del cuento. } \\
\text { La docente entrega hojas, lápices, borradores, } \\
\text { tajalápiz y una caja de lápices por grupo ellos } \\
\text { escriben lo que les gusto o no de la lectura y } \\
\text { qué adaptación le harían al cuento. En seguida } \\
\text { algunos niños socializan por ejemplo "a mí me } \\
\text { gusto que la mamá volviera" "me gusto que la } \\
\text { mamá se hubiera ido para que ellos } \\
\text { aprendieran como se siente hacer todo" "No } \\
\text { me gustaba como trataba el esposo y los hijos } \\
\text { a la mamá" "me gusto que al final el esposo y } \\
\text { los hijos le colaboraran a la mamá". Una niña } \\
\text { propone un personaje "voy a ser la hermana de } \\
\text { Marisol y ellas se quedan viviendo un tiempo } \\
\text { en la casa" }\end{array}$ & $\begin{array}{l}\text { - Los niños han mejorado su lectura en } \\
\text { voz alta. } \\
\text { - Los niños están motivados para } \\
\text { participar en la lectura colectiva } \\
\text { - Escriben motivados las ideas para el } \\
\text { guión. }\end{array}$ \\
\hline
\end{tabular}




\begin{tabular}{|c|c|c|}
\hline \multicolumn{2}{|c|}{$\begin{array}{l}\text { La docente plantea la enseñanza que deja el } \\
\text { cuento y les pregunta qué proponen para la } \\
\text { escritura del guión. Ellos deciden dejar la }\end{array}$} & \\
\hline \multicolumn{3}{|c|}{ Docente: $\quad$ agregarle más personajessanbura Paola Ramos Moreno } \\
\hline Fecha: & una niña dice "que vayan a & Abril 21 de 2018 \\
\hline Taller: & \multicolumn{2}{|c|}{ en a hacer la comida" iListos, cámara, acción! I } \\
\hline Hora: & 10 & 30 a.m. a $12: 00$ p.m. \\
\hline \multicolumn{2}{|c|}{$\begin{array}{l}\text { borradores, tajalápiz y una caja de lápices por } \\
\text { borrapo y escriben un guión, son ideas que ellos } \\
\text { grupoponen para construir el guión final. }\end{array}$} & \\
\hline
\end{tabular}

\section{DIARIO DE CAMPO No.9}

\begin{tabular}{|c|c|}
\hline Descripción de la actividad & Reflexión \\
\hline $\begin{array}{l}\text { Se comienza con la actividad del coche ciego, } \\
\text { algunos educandos no se orientan bien y no } \\
\text { siguen adecuadamente las instrucciones. } \\
\text { La docente les entrega la versión final del guión } \\
\text { teatral. Se asignan los personajes y se realiza } \\
\text { una lectura colectiva. }\end{array}$ & $\begin{array}{l}\text { - Los niños están entusiasmados con la } \\
\text { - Lbra de teatro y sus personajes. } \\
\text { - Los niños quedaron sorprendidos que } \\
\text { - La versión final del guión les agrado. }\end{array}$ \\
\hline
\end{tabular}




\begin{tabular}{|c|c|}
\hline Docente: & Sandra Paola Ramos Moreno \\
\hline Fecha: & Abril 28 de 2018 \\
\hline Taller: & iListos, cámara, acción! II \\
\hline Hora: & 10:30 a.m. a 12:00 p.m. \\
\hline
\end{tabular}

DIARIO DE CAMPO No.10

Se realiza la actividad de mímica, un compañero le dice a otro en el oído un rol y él lo representa. Los demás adivinan. Se entrega el guión final a cada niño y se hace una lectura colectiva. Se asigna los personajes.
- Quedan motivados para el siguiente taller para comenzar ensayo. 


\begin{tabular}{|c|c|}
\hline Docente: & Sandra Paola Ramos Moreno \\
\hline Fecha: & Mayo 5 de 2018 \\
\hline Taller: & Ensayo de la obra de teatro \\
\hline Hora: & $10: 30$ a.m. a 12:00 p.m. \\
\hline
\end{tabular}

\section{DIARIO DE CAMPO No.11}

\begin{tabular}{|c|c|}
\hline Descripción de la actividad & Reflexión \\
\hline $\begin{array}{l}\text { La docente entrega los guiones a los } \\
\text { educandos. Luego, definen los espacios y } \\
\text { colocan los nombres en la pared como: casa de } \\
\text { la familia, jardín, colegio, casa de la tía, cocina } \\
\text { y oficina de la directora. Comienza el ensayo, } \\
\text { han faltado algunos niños, pero se reemplaza } \\
\text { por el momento para no interrumpir las } \\
\text { escenas. Se les corrige postura, expresión } \\
\text { corporal, tono de la voz, entonación y } \\
\text { desplazamientos. En esta sesión se hacen dos } \\
\text { ensayos generales. }\end{array}$ & $\begin{array}{l}\text { - No asisten todos al ensayo por motivos } \\
\text { personales. } \\
\text { - Se debe trabajar más para la } \\
\text { presentación final. }\end{array}$ \\
\hline
\end{tabular}


Anexo 4

\section{UNIVERSIDAD SANTO TOMAS}

\section{GUIÓN TEATRAL ADAPTACIÓN DEL LIBRO DE LOS CERDOS}

NARRADOR (Darline): El señor de la Cerda vivía con sus dos hijos, Juan y

Simón, en una casa bonita con un bonito jardín y un bonito coche en una bonita cochera. En la casa estaba su esposa.

NICOLÁS (Santiago) ¡Apúrate con el desayuno, querida!

JUAN (Samuel): ¡Apúrate con el desayuno, mamá!

SIMÓN (Sebastián): Voy a llegar tarde, mamá

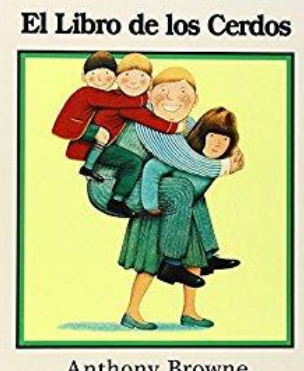

Anthony Browne

MARIANA (María José): No griten a mi mamá, voy a ayudarle en la cocina

MARISOL (Angie): Gracias hija tu ayuda es muy valiosa para mi

NARRADOR (Anyela): Ya que se iban, Marisol lavaba todos los platos del desayuno... tendía las camas...pasaba la aspiradora por las alfombras...y se iba a trabajar.

(Marisol llega a la casa, en seguida llega el esposo y sus hijos)

JUAN Y SIMÓN (Samuel y Simón): ¡Apúrate con la comida, mamá!

NICOLÁS (Santiago): Vieja, apúrate con la comida, tenemos hambre

MARIANA (María José): Mi mamá también tiene hambre y está cansada porque acabo de llegar del trabajo

(Marisol sirve la comida con la ayuda de Mariana)

NARRADOR (Darline): Tan pronto acababan de comer, Marisol lavaba los platos... lavaba la ropa... planchaba... y guisaba de nuevo.

MARIANA (María José): Mami vamos al jardín a sentarnos un rato MARISOL (Angie): Si es una buena idea, ya que estoy muy agotada 
(Marisol y Mariana se sientan en el jardín, de repente una flor les habla)

FLOR: Ustedes deberían darles una lección a ellos

MARISOL (Angie): ¿De qué hablas?

MARIANA (María José): Ellos no ayudan en la casa

MARISOL (Angie): Lo sé, estoy muy aburrida. Solo tú me ayudas

FLOR: Piensen cual sería la mejor forma que ellos reconozcan su error y aprendan

MARIANA (María José): ¡Ya sé! Vámonos de la casa

MARISOL (Angie): Si es lo mejor... solo por un tiempo

(En ese momento pasa la vecina con su hija)

VECINA (Anyela): Hola Marisol y Mariana. ¿Por qué tan tristes?

MARIANA (María José): Tenemos un problema en la casa

HIJA DE LA VECINA (Melany): ¿Cuál?

MARISOL (Angie): Mi esposo e hijos no nos quieren colaborar en la casa

MARIANA (María José): Estamos cansadas y queremos darles una lección

VECINA (Anyela): ¿Piensan irse de la casa?

MARISOL (Angie): $\mathrm{Si}$, pero no sabemos para donde irnos

VECINA (Anyela): Yo me voy para un viaje si quieren ir conmigo

MARIANA: No puedo faltar a clase

MARISOL (Angie): Es cierto vecina. Gracias por su buena intención

VECINA (Anyela): Me voy. Estoy pendiente por si cambian de decisión

MARISOL Y MARIANA (Angie y María José): Gracias

MARISOL (Angie): Voy a llamar a tu tía

MARIANA (María José): Dile que nos deje quedar en su casa

(Marisol llama a su hermana y le cuenta lo sucedido)

TÍA (Darline): Por supuesto mi casa es como si fuera tuya. Aquí las espero.

(Llegan Marisol y Mariana)

MARIANA (María José): Hola tía. ¡Qué alegría verte!

TÍA (Darline): Me siento muy feliz que vengan a mi casa

MARIANA (María José): Hola abuelita

ABUELA (Luisa Aponte): Hola nieta ¡Qué linda estás!......Hola hija

MARISOL (Angie): Hola mamá y hermanita ¡Qué pena molestar! 
TÍA (Darline): No se preocupen estamos para colaborarnos y más es una situación difícil ABUELA (Luisa Aponte): Ellos sin ustedes no podrán sobrevivir, es bueno que se queden aquí unos días. Así Nicolás, Juan y Simón se arrepentirán y no volverán a caer en el mismo error.

NARRADOR (Anyela): Una tarde, cuando los muchachos regresaron a casa no hubo nadie que los recibiera.

JUAN (Samuel): ¿Dónde está mamá?

SIMÓN (Sebastián): Mamá, ya llegamos

NICOLÁS (Santiago): ¡Marisol, Marisol!..... ¡Mariana, Mariana!

NARRADOR (Darline): No las encontraron por ninguna parte. Sobre la mesa encontraron un sobre. Nicolás lo abrió. Adentro había una hoja de papel.

NICOLÁS (Santiago): Hijos su madre dejo una nota que dice: "Son unos cerdos"

JUAN (Samuel): ¿Por qué cerdos?

NICOLÁS (Santiago): Y ahora ¿Qué vamos hacer?

(Entran las mascotas de la casa)

PRINCESA (GATA) (María Fernanda): ¿Mariana y Marisol dónde están?

MUÑECA (PERRO) (Luisa Doria): ¿No sé?

PRINCESA (GATA) (María Fernanda): Vamos a buscarlas

MUNECA (PERRO) (Luisa Doria): Si, vamos

(Nicolás, Juan y Simón se convierten en cerdos)

NARRADOR (Darline): Al día siguiente Juan y Simón llegan al colegio convertidos en cerdos

PROFESORA (Angeli): ¿Qué les ha sucedido Juan y Simón?

CAMILA (María Paula): Se han convertido en unos cerdos

JUAN Y SIMÓN: Mi mamá se fue de la casa

PROFESORA (Angeli): Esperen un momento voy a llamar a la otra profesora para solucionar este problema

CAMILA (María Paula) ¡Están sucios sus uniformes!

(Entran las dos profesoras al salón)

PROFESORA (Vanesa): ¿Por qué su mamá se fue de la casa?

JUAN Y SIMÓN: No sabemos 
PROFESORA (Angeli): Debemos llamar al papá a su trabajo

PROFESORA (Vanesa): Si, tenemos que ayudar a solucionar el problema. Me acuerdo que en una reunión la mamá me contó que ellos no le ayudaban en las actividades del hogar, por eso debió tomar la decisión... Lo mejor es informarle a la directora

PROFESORA (Angeli): Vamos niños

(Llegan a la oficina de la directora)

PROFESORA (Vanesa): Los estudiantes llegaron en esa condición

DIRECTORA (Isabella): ¡Qué horror! Voy a llamar a su padre.........No contesta el teléfono.

PROFESORA (Angeli): No se preocupe directora yo los llevaré a su casa

DIRECTORA (Isabella): Está bien queda encargada de los estudiantes

PROFESORA (Vanessa): Voy con ellos

(Llegan a la casa y Nicolás abre la puerta)

PROFESORA (Angeli): Necesitamos hablar con usted

NICOLÁS (Santiago): No tengo tiempo ¡Entren hijos!

NARRADOR (Anyela): Juan y Simón entraron y cerraron la puerta. Tuvieron que preparar su comida. Tardaron horas y horas y les quedo horrible. A la mañana siguiente tuvieron que prepararse su desayuno. Tardaron horas y les quedo horrible.

SIMÓN (Sebastián): No voy a lavar los platos

NICOLÁS (Santiago): No voy a lavar la ropa

JUAN (Samuel): No voy preparar la comida

JUAN Y SIMÓN (Samuel y Sebastián): ¿Cuándo regresará mamá?

NICOLÁS (Santiago): ¿Cómo voy a saberlo?

NARRADOR: (Darline): De repente se aparece dos hadas

HADA 1 (Carolina): Vamos a concederles un deseo

NICOLAS: Queremos que vuelva Marisol y Mariana. Nos hacen falta

JUAN Y SIMÓN: Si, por favor

HADA 2 (Laura Daniela) Ayudemos a ésta familia

HADA 3 (Laura Sofía): De acuerdo, pero tienen que prometer que las van ayudar en las actividades del hogar.

HADA 4 (Stefanny): Les brindarán amor y cariño. ¿Lo prometen?

NICOLÁS: Lo prometemos 
NARRADOR (Darline): Muy pronto, la casa parecía un chiquero. Una noche no hubo ya nada para cocinar.

NICOLÁS (Santiago): No nos queda más remedio que buscar por todas partes algunas sobras

NARRADOR (Anyela): En la casa de la hermana de Marisol, se presenta un ángel.

ÁNGEL (ALISSON): Hola Marisol y Mariana, tienen que volver a su casa porque ellos ya aprendieron la lección

MARISOL (Angie): ¿Cuándo debemos regresar?

ÁNGEL (ALLISON): Mañana

MARIANA (María José): Así será querido ángel

NARRADOR (Anyela): Mariana y Marisol entran en compañía de un hermoso sol

SOL (DANA): Si valoran a estas hermosas mujeres la luz brillará para siempre en esta casa

NICOLÁS, SIMÓN Y JUAN (Santiago, Sebastián y Samuel): Por favor regresa

NICOLÁS (Santiago): Prometemos ayudarte en todas las actividades de la casa

MARISOL (Angie): Espero que me colaboren y me respeten

MARIANA (María José): Todos debemos realizar todas las actividades del hogar

NICOLÁS (Santiago): Voy a lavar los platos

JUAN Y SIMÓN (Samuel y Sebastián): vamos a tender las camas

MARIANA (María José): Voy a planchar

MARISOL (Angie): Vamos a cocinar entre todos

TODOS (Santiago, Samuel, María José, Angie y Sebastián): ¡Sí!

NICOLÁS (Santiago): Vamos al parque para compartir como una familia

MARIANA (María José): Qué felicidad

MARISOL (Angie): Qué hermosa familia

JUAN Y SIMÓN (Samuel y Sebastián): Somos muy felices 
